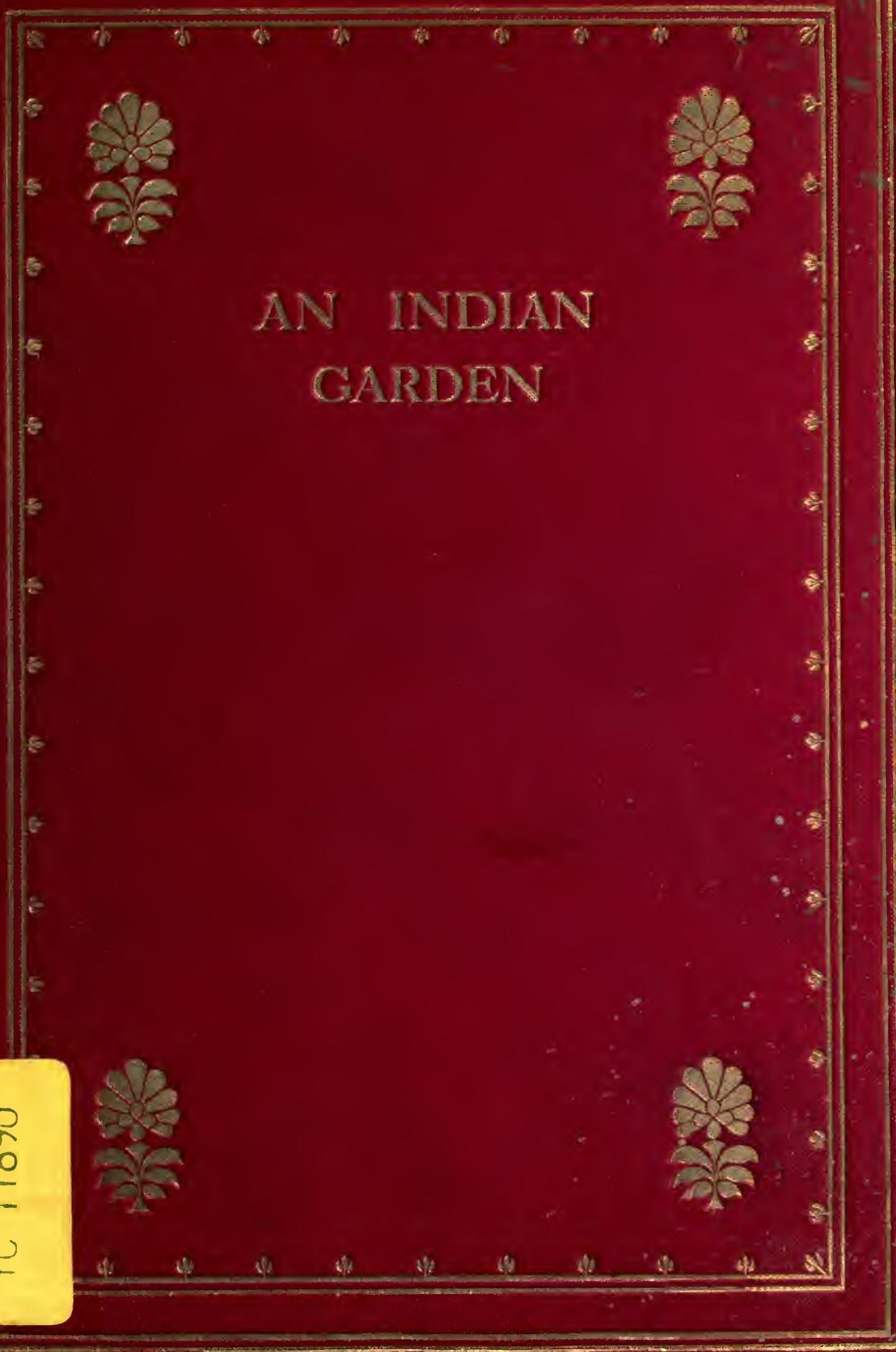




\section{BERKEI E $Y$ \\ LIBRARY UNIVERSITY OF CALIRORNIA}

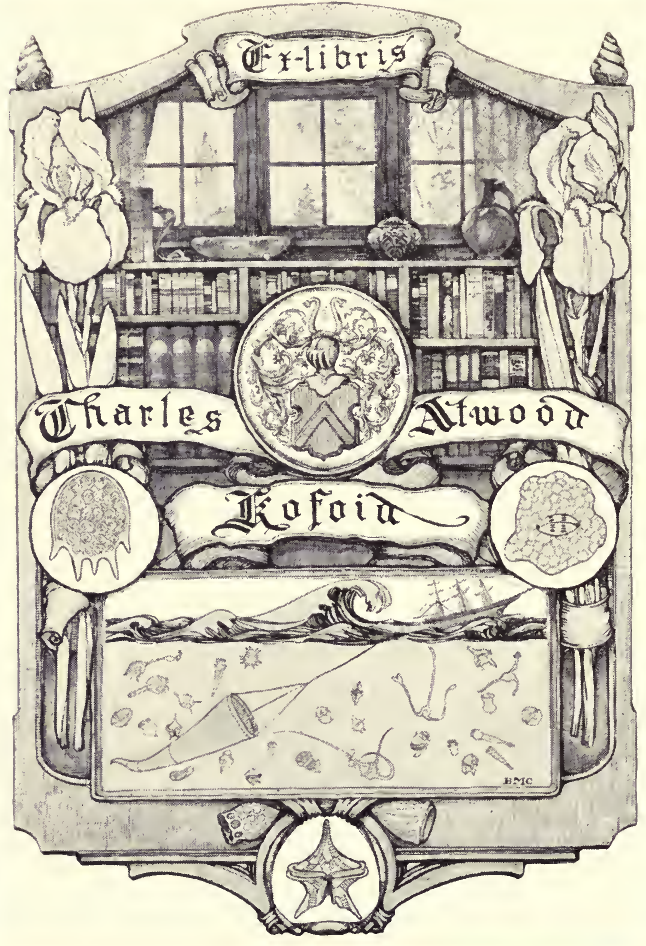



AN INDIAN GARDEN 




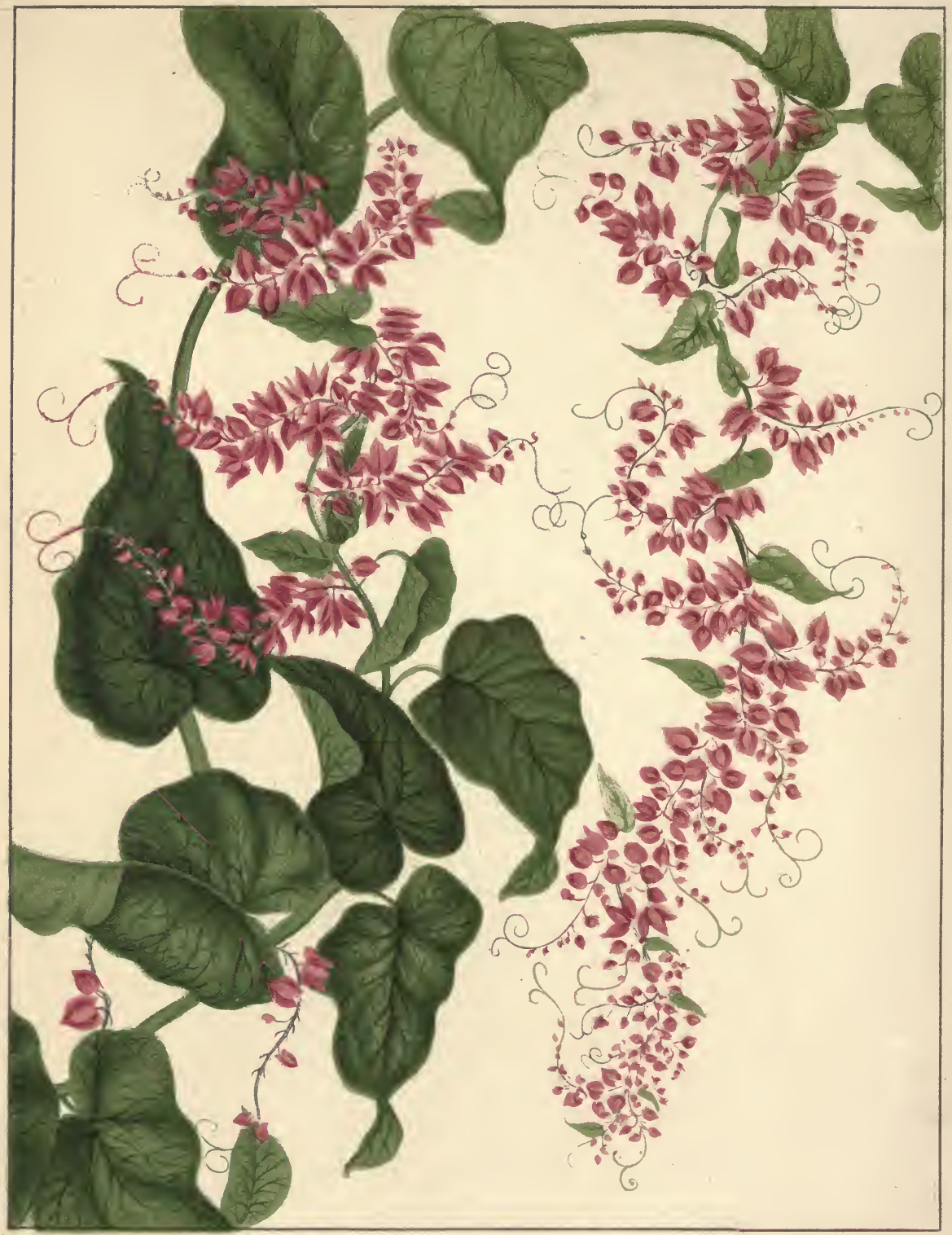

ANTIGONON.

Nat. ord. Polygonaceae. 


\section{AN INDIAN GARDEN}

BY MRS HENRY COOPER EGGAR

WITH COLOURED FRONTISPIECE, AND EIGHTEEN ILLUSTRATIONS

NEW YORK

JAMES POTT \& COMPANY

LONDON : JOHN MURRAY

1904 
Printed in Great Britain 


\section{PREFACE}

My preface must be an apology. When I first wrote these gardening notes, I had no intention of rushing - where angels fear to tread - into print! They were written with the object of amusing an invalid relative at the Antipodes, in the hope that she would be interested in reading of some of our experiences in this (to her) unknown land. But they never reached her, as she died before I could finish them. They have, however, been read by friends, who have encouraged me to offer them to the public; and although they may not be so novel to many as they would have been to her, I hope my little descriptions of daily doings in India may find an indulgent reader or two, both there and elsewhere.

\section{E. M. EGGAR.}

Alipore, Calcutta,

June 1904. 



\section{O N TENTS}

\begin{tabular}{|c|c|c|c|c|c|c|c|c|c|}
\hline & & & & & & & & & PAEE \\
\hline APRIL & • & - & - & - & - & - & - & . & $\mathbf{I}$ \\
\hline MAY & - & • & • & • & - & - & - & • & 39 \\
\hline JUNE & - & • & & • & • & • & - & • & 73 \\
\hline JULY & - & • & $\bullet$ & • & - & • & • & • & 112 \\
\hline AUGUS & & - & - & . & - & - & . & . & 145 \\
\hline
\end{tabular}

\section{LIST OF ILLUSTRATIONS}

Antigonon (Coloured Plate)

Critics in the Chamber of Horrors

The House and Pond

JOGEe's Vegetable Garden

The Grey Beard. The Imp

CASUarinas .

THE LEAN-TO

THE ReD-HatTed DOOR-KeEPER. THE SWeEPer'S
Frontispiece

- To face page 8

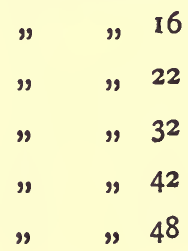

9

" 66 
A Coolie among the Plantains - To face page 80

A SPRig of the FrangipanNi Tree. Bermuda

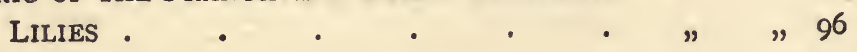

MY NOBLE W'ARRIORS . . . . " " " 102

THE ROSE GARDeN . . . . . . " " "

The POND . . . . . . . . " "

Palmyra Palm . . . . . . . " "

The West Walk • . . . . " " " " 138

Eucharis lilies. CRinum AUgustum . . " " 144

THE SOUTh-West Corner of THE GARDen . " "160

Jogee and Damon. The Dogs' Last Battlefield " " 176

THE DRop SCENE • : . • • " " " 180 


\title{
AN INDIAN GARDEN
}

\begin{abstract}
APRIL
"Softly the Indian night sinks on the Plains."

Light of Asia.
\end{abstract}

My garden is not in the least like a lovely European one, nor will it compare with any in the Himalayas. It hasn't a beautiful climate and its air is never bracing. It is really and in truth, a "plain" garden, being situated about 3 feet above sea-level, with never a rise, sufficient to be called a hill, anywhere near for 100 miles. The jungle adjoins it on one side, wild and rampant, and seems to be always sending its roots down under the old wall, and endeavouring to obtain possession of my domain. Also it is old, very old, and it has many trees, and much shade, and an area of $5 \frac{1}{2}$ acres. When the thermometer in the hall stands 
anywhere between 80 and 90 degrees (not above), and most folks are shut indoors, behind windows and shutters, trying to keep cool-behold this foolish person out in the garden under two umbrellas, refreshing herself with a sight of the flowers newly opened since yesterday, and devising fresh plans and alterations, in that particular portion of the premises that has been conceded to her for her "very own." Here I can garden after my own heart without any of my methods clashing against those of the master of the household. The Burra Sahib and the Ancient are very scientific gardeners when, poor things, they have the time to attend to it; but I am a complete ignoramus, and all I know is from experimenting. Therefore, I fear, perhaps, my "notes" will not be very definite. Some one has wittily said, "If you cannot be definite, then you had better be dumb-in-it," but gardening itself is such a very disconnected kind of occupation, now here, now there, that one may be forgiven for being discursive in writing of one's everyday doings, especially in such heat!

I have the whole livelong day to myself, now, with no opportunity of taking a breezy four-mile 
walk before lunch, as I should like to, or of running out on my ten toes, to do a little shopping at any hour of the day I wish. I contrive though to exist with as little as possible of the latter just now. At this time of year shopping in the daytime only entails weariness and discomfort for me, and possible sunstroke for the horses, so the garden is a blessed resource, during these six bad months of hot weather. Besides the pleasure it is to me personally, it is good for the whole establishment, to have some one always available, seeing that untidy places are made pleasant to look at, paths weeded, stones removed, unsightliness beautified, and rampant waste and damage checked. A garden loses half its beauty unless kept tidy, and in this country deterioration very quickly sets in.

These men, too, never can work properly unless under an overseer. It is their custom to labour with their hands only; some one else must supply the brains, and guide the fingers. Generally, the knowledge we exiles possess of the language is too limited to enable us to give intelligible orders, so we have to stand by and watch each detail of work 
being done, giving infantile directions :- "Do this," "Do that,"-and he doeth it; and waiteth for further orders. I must confess one thing, I am not an early riser. Therefore I can only attend to my garden after breakfast, when the Burra Sahib and the Ancient have departed for the day.

First though, the little old grey-beard butler keeps me to my duty, by placing before me an alarming array of books, and a pencil. I have to put down so much milk, and ice, and soda water used yesterday; which he recites as if from a lesson; and to write for "whisky" and "jahm""E-strawby jahm," he wants for the breakfast. Then there is a "bout" with the cook to go through, and the "billy-fare" to write, which the Burra Sahib likes to have in front of him morning and evening, however small the ménu, in order to choose out the most vegetarian of the dishes. On the occasion of a party the cook appals me with French, and makes me write, "Potage á la bonne femme; Cotelettes de bekti au sauce Hollandaise; Volaille en demi-deuil," etc., but for every day I abbreviate it as much as possible, and when the master sits down to dinner in the bosom 
of his family, he sees he is to have only, say:"Clear soup, Fish roll, Pig roast, Cab. pud.," with a toast or two.

"Pig for dinner, in this country?" he remonstrates.

"Oh, that's Pigeon," I explain; "but I was in a hurry."

Then the cook offers for my inspection a book, in which the first items every day are exactly the same.

"Soup 6 annas, Fish 2 rupees." I know it by heart.

"What's the demnition total ?" as Mr Mantalini would say. Of course more than it ought to be, but as everything is bought at auction, it is difficult to know exactly what he paid.

$\mathrm{Ha}$ ! here is something new though, "Joyful pot, 2 annas." Whatever do we want with a new pot, and why a joyful one? Does it bubble over with joy in boiling, or what? Inquiries elicit that it is a nutmeg grater only. Pass.

While I am consulting my six cookery books for a new dish for the morrow, after declining the chef"s suggestion of "Bubbling Cook," by which 
he means Bubble and Squeak; I see behind the door-shadows-half figures-like the mysterious woman in the corner of the Wiertz Museum in Brussels. They are all waiting for an audience, and rupees; more than all-rupees. One is holding a broken lamp-chimney, another broken harness, the doorkeeper has letters in books to be signed for, or answered immediately, and bills to be paid, and all stand there waiting for money. Having disposed of all these, then there is an interview with Penelope, who sits flat upon the floor of the verandah, and unpicks each day what he sewed yesterday. Not only that, but often after making some garment too small, he carefully and neatly cuts off all redundant turnings, without first presenting it for approval. This language fails one on such an occasion. There is no word in it that expresses all one's disappointment, worry, and vexation, in sufficiently forcible terms ; or, if there is, I do not know what it is !

So out into the garden I go for relief; straight down to the thick green shade by the south wall, where my experimental gardening goes on. Here there are two old mango trees, and a large Brownia, 
all close together ; forming an excellent roof for an out-door conservatory, and requiring no artificial shade whatever. Nothing grew here, originally, but rank weeds and jungly grass; but little by little, it has developed into a charming sort of wilderness, with irregular beds of stove plants, round the base of the trees; and small round ones dotted about, with curly paths in between. Orchids, tied by the necks to bits of old mango wood, and ferns in baskets, are hanging from the branches. Every part of it is extremely irregular, with not an atom of design. "Through many devious paths I tread," when I come here.

The first time the Burra Sahib and the Ancient were invited to look at and admire it, as a finished whole, they named it "The Chamber of Horrors!" I had fastened some very large orchids to two mango stumps planted upright in the ground; across the tops of these was laid another, and from the middle of that depended a fern in a basket. Below were groups of white crinum lilies and maiden hair (adiantum lunulatum). I hoped they would say this at any rate looked picturesque, but they declared it was just like a "Bhootia's Grave," 
and that is the name it has ever since gone by. What they love are ornamental beds, cut out of the lawn in geometrical designs, edged all round with neat tiles, and filled separately with phlox, verbena, petunias, and pinks; planted exactly 6 inches apart. So do I ; and the master is particularly good at laying out, with innumerable pegs, and miles of string, the most quaint devices, all mathematically accurate. One design looks rather like an electric fan, swishing round with its load of pansies and phlox. In another place there are the four aces. The ace of clubs is full of pinks; that of hearts is composed of geraniums and petunias; the ace of diamonds contains carnations; and spades is full of verbenas. These all look extremely smart in the winter, but for eight months in the year they show nothing but dry earth, or weeds.

Then is the time for my wilderness, for there is sure to be something cropping up in it, all of its own sweet wild accord. You get down to it by just rushing from shade to shade. From the house to the Debdar Walk, there is a small bit of "scorchiness" to encounter coming up from the gravel drive, which seems to burn one's eyes out 


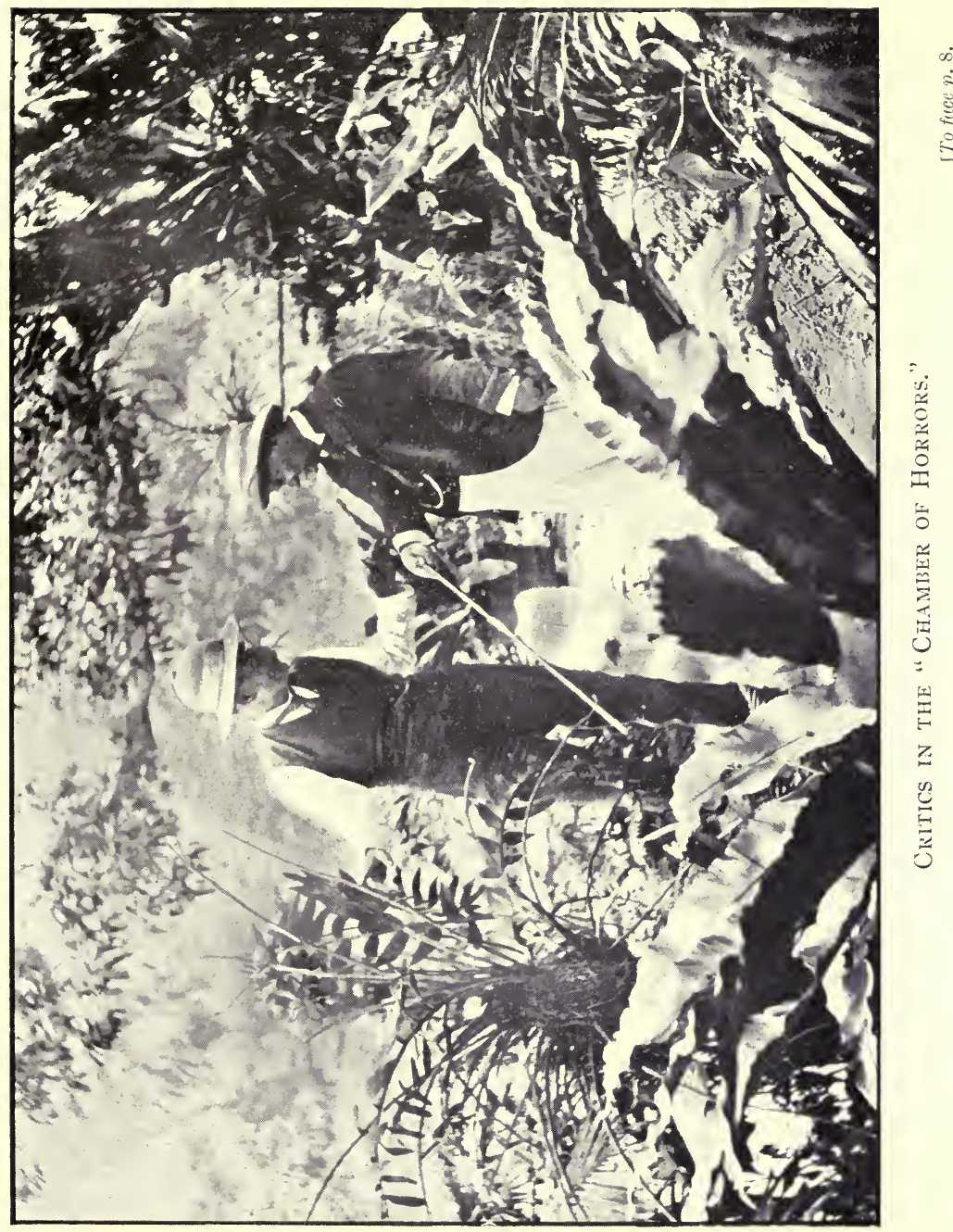



for a minute; but once under the trees, the heat is quite bearable. From the end of this Debdar avenue, to the first two great mango trees, that stand some distance apart, is all shade and green lawns. "Under the Mangoes" is the name of this walk. Then a bit of sun past the rosary, and there you are! seated in a wicker chair, under the other mango trees in the "Chamber of Horrors" without any need for an umbrella. How infinitely preferable to the four walls within doors! How much more lonely one would feel there, imprisoned all day from ten to five, with never a footfall, and never a voice cooing to the birds; now she is gone. I sit here till by-and-bye, through the leaves, I see a faithful little old figure, with a white beard, and flapping white garments. I feel like a child being fetched in to meals, after playing in the mud.

"Will your honour be pleased to come into tiffin? Two o'clock is."

"No, my honour will not be pleased to come into tiffin. Bring it here; a biscuit, and a glass of water and much ice."

For why? Because I have captured an odd man, who eats his dinner at another hour than the 
gardeners, and who is here, weeding, pulling up, cutting down, and moving plants under my directions; and this employment is too fascinating to leave off; especially as in another hour the gardeners themselves will have returned, and I have a lot for them to do to-day.

Across the path that divides this Chamber of Horrors from the pot garden, there stand, enjoying morning sun only, 350 pots of Eucharis Amazonica. In the beginning of February these lilies burst suddenly out into a mass of sweet, white blooms. It was quite worth while to take a chair and book down there, and sit beside them, just to inhale their exquisite odour. It looked like a snow-field.

Then came the pink and red Amaryllis. There are about 300 of these in pots, and crowds in the earth also in different places. These shoot up from the middle of their evergreen, ribbon-like leaves, with their lovely blossoms 3 or 4 inches across. There is another variety whose leaves are deciduous, and one forgets all about it, or where it was planted, till in May one is mightily astonished to see a long, green stalk-emerging from the border, where the earth is baked as hard as a brick and looks as if a 
pick could not open it; at the top of this lonely stalk there blooms out a pale delicate pink lily. Such a lost child in the desert it looks, with not a leaf near it; probably it has not had a drop of water for months. A sort of orphan with nothing to support it. So in view of a coming nor'-wester I hasten to supply it with a backbone of twig. A whole row of these came out in the border unexpectedly, and delighted me, and more in a rockery.

Before these are all over comes the double yellow-fringed lily, planted in a bed on the outskirts of the Chamber of Horrors; such a large handsome flower with yellow, curly fringe. I began the culture of this lily with one bulb only, in a pot. I planted it out after flowering, and the next year it had increased to several. The year after that, I had thirty in pots, and several more in beds without any trouble.

Next April there will be masses of colour visible from this retreat, for all along the edges of the rosary are buried all the surplus Amaryllis, whose pots had got broken; and in front of them is a long row of the tiny pink Zephyranthes, which 
comes out something like a crocus, after a shower of rain or two. That is on one side of the path.

On this side is a collection of beds of yellow marguerites, which exist green all through the torrid year, taking no notice of anything, whether they get too much water or none at all. In June the flowers come out a fine yellow, and look very gay for months. Opposite to them is a group of sunflowers-the small kind-out now ; most useful for indoors.

But the most wonderful of all is a little wild flower (Ruellia) that I picked up from a rough bank near the old pond. There was only one, but it seeded itself, and became many the next year. Last September I planted a long border of them under the hanging orchids, and now they are all out, a perfect vision of mauve petunia-like flowers shading into a purple centre. They have flung seeds to left of them and seeds to right of them, which are all in full bloom too; and one even treads on them in the pathways. Left alone for a year, the place would be one mass of the beautiful little things, for they grow in any crook or cranny, without the slightest cultivation. I had no idea I 
should get so much pleasure out of this wild thing. There was another wild flower that I saw once, something like a large blue lobelia (the Turenia). I very much wanted to capture this and tame it, but I saw it only in the hot weather, when I was afraid to move it. But I managed to get some seeds of it, and it is now rampant everywhere.

Sometimes I think this garden is under a blight, or spell; for plants that are most carefully packed into deep round holes, filled with every kind of food that their souls love, refuse to bloom or grow, or do anything but look stunted, weedy, and wretched. It may be that time is all they want; but along come the Burra Sahib and the Ancient, like Tweedledum and Tweedledee; and they gaze critically.

"Of course it can't grow; it isn't planted properly."

"Likewise it hasn't got the right kind of earth," so up comes the poor thing, and moves house all over again; which is often fatal.

There is a grave in this garden, down at the far end, where Jogee grows his cabbages. I want him to smooth it down, and consider it as garden; for 
no one knows if anything was really buried there at all, or whether it is human or animal. It is only a mound, with a few bricks packed round. Some one suggested it was a pony. If so, it surely would not mind having nice peas and tomatoes growing out of its toes, instead of rank tall weeds and untidy jungle !

But Jogee says he dare not; for once a coolie in the garden was disrespectful to the grave, and a "bhoot" sprang out, and knocked him down; whereat he fell ill, and had to go to his country; and there he died. I remember the coolie asking for leave to go home, but I never knew that was the reason. I thought he had an attack of fever, incurred through swimming about in the pond, trying to catch my ducks.

They were such stupid things, those ducks! They never knew when it was bedtime, nor would they ever go home of their own accord, to be locked up in the go-down. To be left where they were would entail a certain end from jackals. So every evening the cook had to go and catch them.

I was there one day, and thought he seemed rather handicapped all by himself; as every time 
he made a dash at a duck, it dived. So to allow of his speedy return to his cooking, I called the coolie to come and help. He came, with a rope, and Poonia at the other end; and together they marched along on the opposite sloping sides of the pond, just touching the water with the rope behind the ducks, who continued slowly and steadily swimming towards the other end; where the cook was squatting at the water's edge with an open basket, for them to walk into.

"Ah," said the Ancient, "that's the way to do it ; these natives know how to manage ducks."

I stood looking on with interest-these refractory ducks were now going to be captured with the greatest ease-just a little more and the cook would have them.

Not a bit of it! As soon as they got to within 6 feet of him, the eleven ducks turned as one man, and waltzing over the rope, began the journey all in a row straight back to the other end. Away went the cook to await their arrival there, and along went Poonia and the coolie with the rope, gently, so as not to flurry them; when the same thing happened all over again. Another turn, another 
skip, in such beautiful order; it seemed like an exercise. It was so comical that we shrieked with laughter. The stolid Orientals didn't laugh; they had been told to catch those ducks, and they continued to try; without a smile. Every time the ducks turned, they did the same, over and over again, till we had to sit down on the bank, too weak, from laughing, to stand.

Now the snake-catching fox-terrier arrived on the scene.

"Ah," he said, "I'll catch them for you," and into the water he dashed after them. The coolie at once followed suit, and now we thought the end was near. At any rate they would get them out of the water. There were the ducks, swimming for dear life, followed by the coolie and Nous. Near the end, the coolie made a grab under the water, at the legs of one duck. It instantly dived; so did the coolie, so did Nous, and all the other ducks; and on the surface of the water was nothing. In a minute up came the coolie and Nous, empty-handed, and spluttering; at the far end the ducks, flapping their wings and quacking triumphantly. Victory was to the ducks, for when they had had enough of 


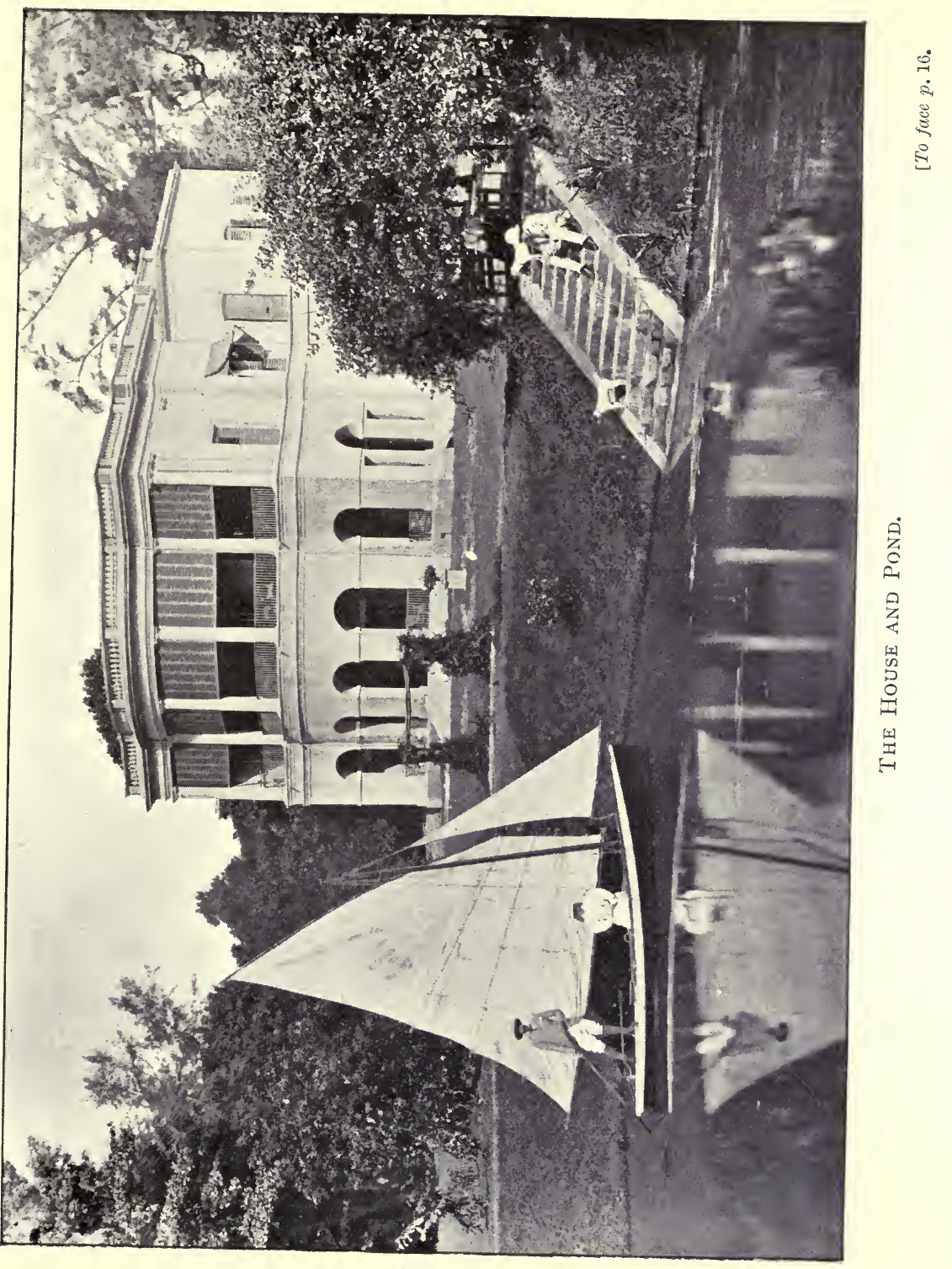



this new game, they quietly walked up the bank and went home. The coolie had tea-and-sugar administered unto him, and was ordered to go and change his small garment, but he took fever and leave the next day, and we saw him no more.

Four of those ducks were only on a visit to us. They belonged to a friendly chummery near by, and came to be taken care of while their owners were away. They were fine white birds, and Unda called each by its owner's name. I don't know how she knew one from the other, but she did. When the chummery returned, she took the four ducks up to her room, and gave them a beautiful bath, with Pears' soap; then tied blue ribbon round their necks, and sent them home in a basket. They came back, however, with a polite note, begging her acceptance of them.

It was rather funny about my own ducks, and their arrival. They were presented to me by a friend who was leaving for home, and $I$ was to send for them. The man I selected to go, as being the one most at liberty just then, was the dishwasher, by name, "Canary." He was a tall man about forty-five years old; and he was sent with a 
large flat basket, to bring home my twelve fine fat ducks. After a considerable time he returned, weeping and stretching out his hands, in a great state of indignation.

"Whatever calamity can have happened?" I asked. "What is the matter?"

Between his sobs he said that he had, after much trouble, got all the ducks into the basket, covering them over with a cloth, and was half way home with it on his head; when suddenly the bottom broke through, the basket fell round his neck, and the ducks flew off in every direction. Into the hedges he had to crawl, on hands and knees, to recapture them, but as soon as he had got some back under the cloth, the others flew out again; he daren't come home for help, or another basket, or they would all have been lost, and he had to make the passers-by assist him; and he wasn't hired to carry ducks, and he couldn't do it again. He would only wash my honour's dishes and light fires.

"But," I said, in the midst of stifled laughter, "have you brought all the ducks?" "Yes, your highness," he said, "all of them." “Then," I 
said, "you are very clever, and you need not be afraid this is going to be a daily custom for you to carry ducks in a broken basket,-it is only this once." Whereat he dried his tears, and went off to his work.

There was another dish-washer, some years ago, who had also an odd experience. The old greybeard butler announced to me at lunch one day, that the dish-washer was ill with fever; but if the mistress would give some medicine, he would soon be able to resume his work. I happened to have none by me, but as the matter was urgent, clean dishes being important, I asked:

"Can he go to the chemist's do you think, for some physic, if I give him a letter? I don't know what to write for." (These being my salad days.) "Oh yes," he said, "he is quite able to go that short distance." I thought that was much the best way, and then the chemist could give him what was proper.

I wrote, "Please give the bearer of this a dose of medicine. He says he has fever." I forgot to inquire about him till two days after. Then I said :

"How is the dish-washer?" 
"He is much better, your honour."

"Ah, then he took the physic?"

"No, your highness, the bazaar coolie took the physic, by mistake."

"The bazaar coolie!" I exclaimed in the utmost astonishment. "Whatever for?"

"The dish-washer said, "Work is, therefore cannot go myself; bazaar coolie goes errands; he may fetch for me the physic.' So bazaar coolie took letter. Shop master prepared physic, then told bazaar coolie to drink it. Coolie said, 'Not for me is the medicine, but for another man. I take it to him.' 'Not so,' said the shop master, 'the mistress has written, give to bearer; and she means you must drink it here.' Many times coolie said he was not the man, but they would not listen, and they made him drink it."

I went into convulsions of laughter; so much so, that the decorous grey-beard himself had to retire into the next room and also smile behind the door. At last I said :

"So the coolie brought back no physic in his hand? Still he fulfilled his errand; he brought it safely enough." 
"Even so," said the butler, "he was a poor man. What he could do? Though he loudly protested, they forced him to open his mouth, and poured the medicine in."

"And the dish-washer has recovered: and the coolie is none the worse." Marvellous people! It is the custom of the country to be employed as a substitute, if possible, for many things; but to do so for taking physic, is, I think, unique.

The lovely white blossom of the jasmine growing over the west side of the palm-house is just over. It has been delightful to gather bits of it, and arrange them with clove pinks and honeysuckle for my table; all sweet. The little flowers came out in clusters all over the creeping plant, and scented the whole palm-house. It has such an exquisite delicate odour. There is another good-sized root of it growing in the rosary, where it is not noticed. I will get up early one fine morning and quietly abstract it, and plant it close to the west verandah; then next year we shall get the delicious scent in the house.

The rosary department belongs to the Burra Sahib and the Ancient. I know nothing about 
budding roses. They do; and they have annexed a great piece of Jogee's vegetable garden, and formed a new rosary; all from slips of Gigantia. In June they are going to bud them with choice kinds, and they promise me blooms on them next January : they say that we shall be a blaze of roses. Marie van Hooutte, Black Prince, Paul Néron, Souvenir de Malmaison, Baroness de Rothschild, Sir Walter Scott, La France, and all the oldfashioned sweet-scented ones.

These will be much more delightful to look at than Jogee's vegetables. His peas never come to anything. If they do have pods at all, the peas are eaten by the birds. His broad beans did grow about 3 feet high last year, looking so homely and nice. But there were only about two flowers on them, the size of those on a nettle, and they never formed into pods any more than the peas. His cauliflowers never flowered, and his cabbages were heartless; they only grew hard, and tough, and were never even cut. He can grow tomatoes and French beans, also parsley, radishes, and lettuces, and so we have left him a bit to play about in. It is very strange, though, because other 


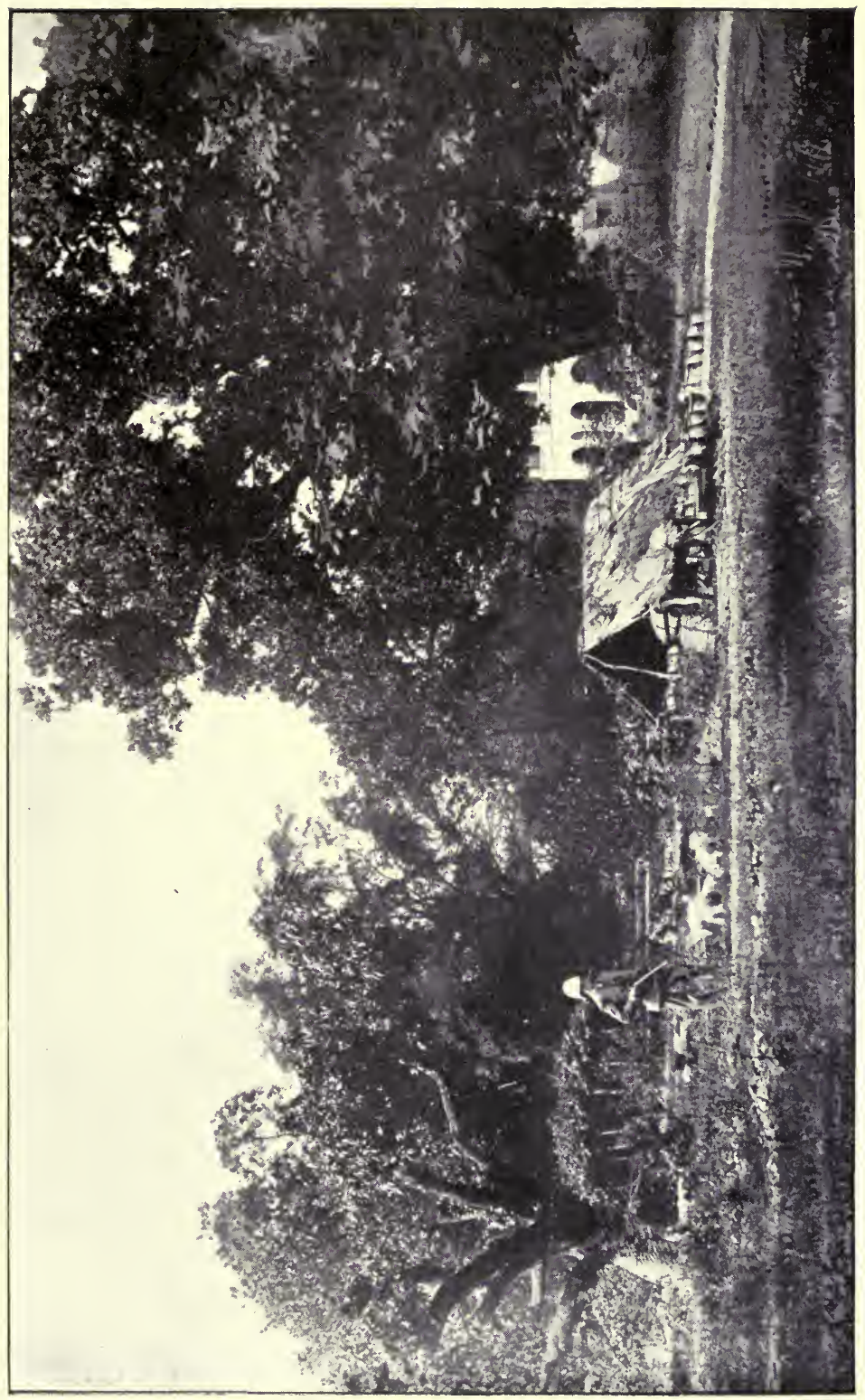

垈 

gardens in the neighbourhood grow fine vegetables of all sorts, and I constantly get presents of whole baskets full of peas, celery, tomatoes, and cabbages, from friends who have more than they can eat. I give Jogee the best seed; I have outside men brought in to thrice dig over the earth; thoroughly cleaning and pulverising it; manure and bone meal are given in proper quantities; shade is supplied when necessary, and water is given in abundance : and all to no purpose. It is either the double line of trees, one each side of the wall, keeping off the morning sun, or it is the adjacent grave.

I think it must be the grave! The other day I observed it was covered with an arrangement of white flowers, closely strung on string in a network design, and surrounded by a row of little clay saucers, which evidently had been filled with oil and lighted, as there were the remains of little wicks. Somebody must have been there doing Poojah the night before, but no one knows who. I wonder if it had any connection with the loss of my gold cufflinks? These people are so strange.

One morning, after breakfast, I was going to dash down to the Chamber of Horrors to plant 
something; but first waited to turn up my sleeves, not to make myself too unpresentable; and placed the links, as I always thought, on the verandah table, with keys, letters, etc., till I came back. On my return, no links! Penelope, respectable and snowy-bearded, said he had not touched them; and the only person who had come on to the verandah was the little $\mathrm{dog}$ and fowl boy, a veritable scamp, if ever there was one; who once left my fowls two whole days without water. I was grieved at my loss; the links having been given to me by the Burra Sahib. I questioned the imp, who looked like a troll with his one eye, and his one tail of hair hanging from the crown of his head over the most picturesque coloured rags. $\mathrm{He}$ answered without a blink in his eye, that he had not taken them.

"But," I said, "do you know what they are like?"

"Oh yes, madam," he said, "I know that they were like little sticks in the middle, and had little round balls at each end."

That was just it! Dumb bells! But how could he possibly have known what they were like, 
unless he had touched them? I thought maybe his little soul could not resist the temptation to take them for toys, so I would not have punished him; but I did so wish he would give them back.

"Ah! the little Shaitan!!" said Penelope, "of course he has got them. If he won't confess, I will hold a 'count-out' in my village to-morrow morning. Then we shall know who was the thief," he added triumphantly.

When he came next day he said, "yes," he had had the "count-out," and all the servants' names had been written down, and the number fell upon the imp.

This was not satisfactory. I had not yet got my buttons, and the imp still denied having taken them. Then up came the doorkeeper and said :

"If your honour wills it, a man there is who has learnt in his own country how to find out thieves; and his will be a very true word, without doubt."

"Where is he?" I asked, thinking they had brought in some juggler.

"It is one of your honour's garden coolies." 
"A garden coolie! How can he find out thieves?"

"If the mistress will give 4 annas to bring the materials to burn, he will go as one unconscious and tell it in his sleep."

"What! Without knowing anything of it himself?"

"It is so ; after making prayer and burning incense, the god of his own country comes, and tells him which is the thief."

"Well, you are a very curious people if you believe that. However, here are 4 annas for the experiment."

By-and-bye he came and requested me to come and see. I found every one of the servants in a circle round the garden coolie, with the boy in their midst, and two or three outside men belonging to other people, and the boy's father, all standing near. There was an earthenware dish, on which was a bunch of plantains, and some dall and betel nut; all of which had been already offered to the unseen god. In front of the coolie was another dish containing something burning. Over the fumes of this he held his head with closed eyes, then 
rocked himself backwards and forwards, apparently in great stress and emotion.

"He speaks," said they. I heard him ask faintly :

"Has the mistress come?"

"Yes," they said, "she is here."

"It is Bhagwan."

"Bhagwan, the boy!" they all ejaculated, and the coolie fell over in what looked like a dead faint. The eyes of all were turned to the poor imp; and even his own father gazed at him sternly. $\mathrm{He}$ said :

"You have been declared by true words; now you must give back the buttons. If you commit a theft and get sent to prison, I will never have anything more to do with you."

But now Bhagwan began to shake, and in a minute to cry; and I felt inclined to say, like Alice in Wonderland :

"You are nothing but a pack of cards!" But I said :

"This is all nonsense; that man knew what he was about, and was not asleep at all ; and they are not true words, and Bhagwan did not take the 
buttons. They are gone and I don't know where they are, but I don't believe Bhagwan took them "; and I left them resuscitating the garden coolie by pouring water over his face, and beginning to peel the plantains, preparatory to eating them. I saw him come to, with a dazed look; and no wonder, after inhaling all that smoke. I picked up a bit of what they had burned, and it looked like resin.

About a fortnight after that I was prowling round by the stables looking at the horses, when I caught sight of a monstrous thing hanging to the banyan tree. It was like a gigantic rag doll, of hideous lean proportions; it was painted black, with arms and legs all akimbo, and a face with wide red mouth, and frightful goggle eyes. It had on a turban and waist cloth, and was hanging by a rope round its neck.

"Whatever is that?" I asked.

"That," said the old groom who has been with us many years, "that is the Shaitan who took your honour's buttons; and every morning and every evening, I beat him very hard till he brings back the buttons"; and he took the thing down, and 
administered some good whacks to it, there and then.

"That thing could not possibly know anything about buttons," I said.

"Oh yes," he said, "he does; he knows all about it, and until he brings them back, I will beat him every day."

I laughed all the way indoors. I had now given up all idea of ever seeing the links again, and the Burra Sahib said he would buy me some more. Without any intention, or knowing why I did it, I went straight upstairs, and idly put my hand into the pocket of a gown I had not worn for some time. What is that in the corner? Something small and hard. I waited a minute and drew slowly out-a small embroidered handkerchief, with something tied up in one end! The dumb bells ! I could not believe my eyes. Try as I would, I had no more recollection of having put them there myself, than I had of flying. My memory was a complete blank; but I felt rather small, nevertheless. However, I immediately announced their arrival, and the imp was cleared.

This was Imp No. 2. I had had a previous 
acquaintance with Imp No. 1, two or three years before, whose doings will ever remain fresh in my memory, for he certainly "did" me! He was my little page boy, dressed up in green and yellow, like a beetle, with a puggree as big as himself. $\mathrm{He}$ had to escort visitors to the drawing-room, carry notes about, and bring cheroots and matches to the Burra Sahib and the Ancient, after dinner. His father and uncle had both been with us for twenty years, and extremely respectable men they were. He was a dear little fellow, with large eyes, and long curly lashes. I always had a weak spot in my heart for boys, and this was such a sharp intelligent child for ten. He always knew what was going on, and could give me any information as to what was happening about the compound, far better than any of the grown-up servants; who, if ever asked any question, that did not refer to money, or rice, would only say, "I don't know," or, "I did not see," when the thing inquired about was happening under their noses. Wherefore I liked Billy Doo; and he was always stationed in attendance, when the others were away four hours for dining purposes. Sometimes he brought me 
up little bills, the money for which I entrusted to him, to give to the man waiting below, and for which he brought up the receipt. My small cash I kept in a locked drawer in my table. I was very surprised once to miss some, thereby not being able to balance my books, but concluded I had omitted to enter some small bill that I had paid. One day I placed a roll of four notes there, of $\mathbf{1 0}$ rupees each, after paying the wages; then locked the drawer and went downstairs, calling to Billy Doo to bring my fan from my room. After dinner I had occasion to go and get some of these said notes. I unlocked the drawer with the keys in my possession. To my surprise, no roll!

"Well, now," I thought, "I must sift this. I am perfectly positive they were there, an hour ago, and no one else has had the keys."

So the two domestics, the sweeper and the duster, who had attended to the room, were brought and interviewed, and acquainted with the loss. Then I observed that the corresponding drawer of the table, which had had its key rusted in for years, not able to be turned one way or the other, looked clean. I took it out, tried it, and it opened my 
money drawer as easily as my own. I held it to the light, and saw that it had been filed on one side, and made to fit. Here was a revelation! I always hate having to accuse servants, but I must know who was the thief.

"You two are the only people who have been in this room to-night," I said, "except Billy Doo, and he it could not have been."

"Oh no," they said, "he it could not have been. Some one very clever it is, to have filed that key in such manner."

Billy Doo stood close by, looking eager and attentive, and examined the key. The next day the police were called in to make inquiries-but with no result. The Burra Sahib said, "Dismiss the lot," but it seemed hard, and I wanted to know who did it, so waited to see if the police discovered anything. Billy Doo did not return from his little dinner till the evening, and then what a pickle he was in! Coat all mud, little trow-trows all torn straight across, with one of the legs hanging loose.

Reproachfully I exclaimed, "Billy Doo! what have you been doing?"

"Oh," he said, "I have been eating my dinner, 


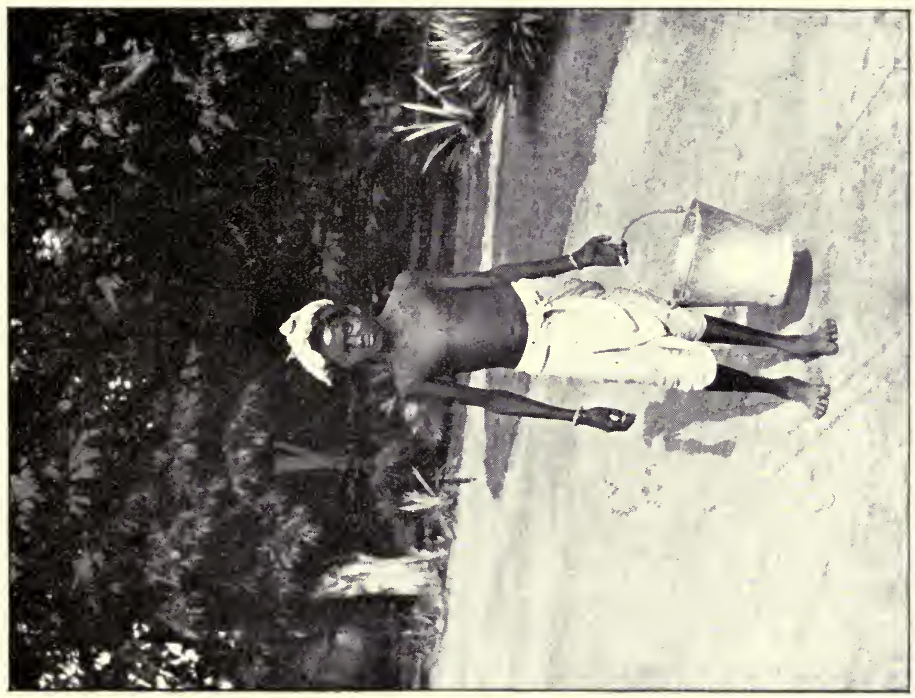

:

焉

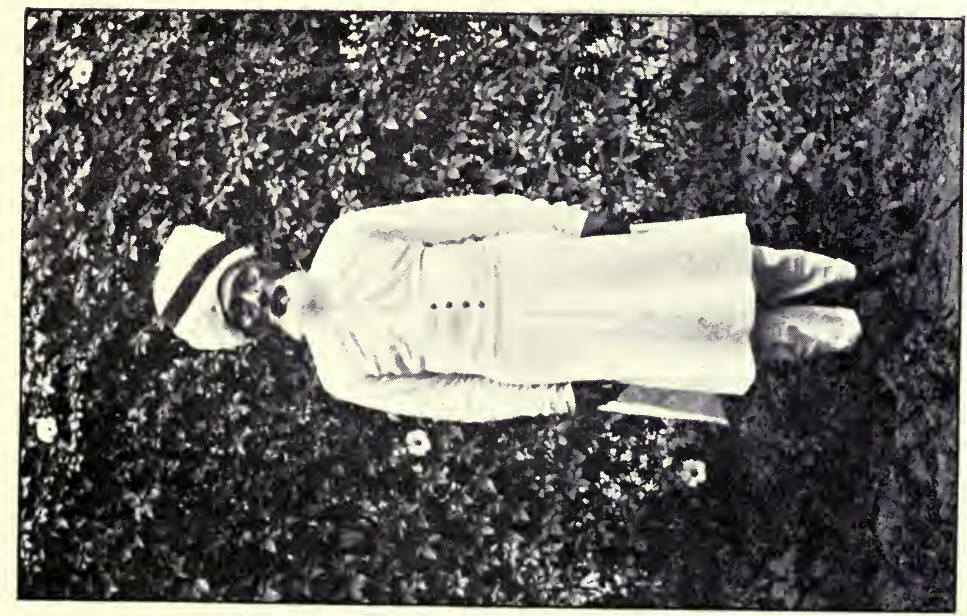

至 

and the cloth your honour gave for clothes is bad, and when I sit, they break"; and he looked under his curly lashes at me sideways, with a look that seemed to say, "Here I am, for you to beat me, or what you like."

I knew he must have been playing with the tennis boys all day, and they had destroyed him.

I said, "Go to your mother at once, and get mended, and I will speak to your father."

He went, and next day there was no Billy Doo; nor the next. Neither his father nor his uncle could find him anywhere. He had not been home to dinner or to sleep, and his mother, ill in bed, was weeping for him. It flashed across me, for the first time, that Billy Doo was the thief; though no one could believe it possible. So I sent for the police again; this time to find the boy; for I imagined if he had all that money on him, some one might throw him into a tank, in order to rob him of it. I sent people out in all directions, and they scoured the city for miles round; though they said, "How could a child go so far? He has never been away from here, where his father and mother live, and would be afraid to go one mile." I was 
very anxious to restore him to his mother, but began to fear that he must have been murdered, and that there would be very little chance of ever hearing anything of him again. As a last resource I said to his father :

"Can he have gone to Dumraon, do you think, where you all came from, and where an expedition has just gone to see the eclipse?"

His father thought it not possible-a child of ten! who had never travelled alone, to make a journey of 400 miles ; but if my honour ordered it, he would send a letter to the head of his family there.

"No," I said, "send a telegram; here is the money." The answer came.

"Yes! Billy Doo was there; also with much money."

Instantly his father said, "I will fetch him," and he went. In eight days, as we sat at lunch, there was suddenly a crowd in the doorway; silently standing, waiting for permission to advance. There was the uncle, and the father, and all the other servants ; and they brought forward an abject little wretch; miserable, whimpering, tattered and torn. 
The father is a man of few words. He simply said, sternly, "This is the thief. I have brought him from Dumraon, and there is what he bought with your honour's money," and he untied a large bundle. There was a gold-embroidered cap, a pair of yellow shoes with red laces, a travelling shawl, a cheroot, a box of native sweetmeats, and an immense concertina, almost as large as the boy. These he placed before me, one by one, on the ground. It was most difficult to keep from laughing; especially at the tragic way in which each thing was presented to me. The Burra Sahib and the Ancient did not even try to be serious. They wanted to know if I were going to add these curios to my collection; especially the musical instrument. I withered them with a look, and they retreated to back seats, smothering their laughter behind their newspapers. The dignity of the Court must be maintained ; and it was a serious offence. The father said that on reaching Dumraon, he was told that the boy had announced that his master had given him money to go and see the eclipse. When he heard that his father was coming, he instantly fled by train to Arrah-the little demon. The father followed; 
the boy again took train to Buxar, where at last he was caught, having spent all my money.

I wanted one point cleared up.

"Did you," I asked Billy Doo, "all alone do this work, or did any one help you?"

"No," he sobbed, "I alone; no one helped me."

"Now," I said, "what is to be done with him?"

"Whatever your honour pleases," said the father, "you are my mother and my father, and I have brought him to you to punish as you think fit."

"If he is not punished he will grow into a bad man," I said. "I think he ought to go to the Reformatory."

"If your honour wills it," he answered.

Now spoke up the Burra Sahib from the corner, "You cannot send the boy to the Reformatory without appearing yourself in the Police Court to charge him. And you could not possibly do that by yourself, and I should not be able to go with you." "Then how are we to impress it on the boy?" "Beat him." 
"Will you beat him?"

"No, I can't do that."

I then offered the boy to the Ancient for chastisement, but he also declined.

So I turned to the father and said the master had decreed, that the boy was not to go to the Reformatory, but that he himself should beat him, and make him learn that it was a great wickedness to steal, and that no one would ever employ him; and then how was he to earn his own living when he grew up?

Then the man's self-restraint gave way. It showed how much he had been feeling the disgrace of it. He fell at my feet, in tears; thanking me for not sending the boy to prison. The uncle, also, knelt and put the dust of my shoe on his head, sobbing his grief that Billy Doo should have done this thing to me, whose salt he had eaten; which in their eyes accentuates the crime. And they were more particularly ashamed, because during the late illness of Billy Doo's poor little brother who died-my former page boy-I had sent him many comforts, and food and medicine, even ice and pillows, and paid his doctor. So Billy Doo 
was taken away and kept a prisoner for some time by his father, and "taught" every day, till an opportunity arrived to send him for good to Dumraon, to be employed in his family's caste-work of milking cows.

Since when I have had no more page boys. It used to be very funny to see him marshalling in the tennis boys, four to a court, for picking up the balls, and standing them all in a line to make obeisance before being paid and dismissed; all of them bigger than himself.

But it was not quite so funny what I heard afterwards that he had said about me. He was one day seen pulling one of the dogs along by a string round its neck, and as he pulled he said:

"Come on, d-n you!"

The Ancient asked him :

"Who taught you such words?"

Billy Doo replied :

"The mistress!" 


\section{MAY}

"Gorgeous Flowerlets in the Sunlight Shining, Blossoms Flaunting in the eye of day."

LONGFELLOW.

THis is the month of blossoming trees, of which this ancient city garden contains a goodly number. In all, flowering and otherwise and quite exclusive of shrubs, there are 102. I have counted them myself. There are nine mangoes, a few teak, a fig, two bael, and five date-palm trees; also jack-fruit, with dark handsome foliage and large yellow, gourdlike, mal-odorous fruit, over the possession of which the servants squabble, but which we cannot endure within 10 yards of us. Old, old Peepul trees (Ficus Religiosa), full of snakes and geckos (which are creatures that lie close to the brown bark of the upper branches all day, and are indistinguishable from it. At intervals they start a curious performance. First they rattle a sort of castanets in their 
throats; then they hiccup their name, "geck-o," about seven times; the last two or three slowly and lazily as if they are quite exhausted, till the last one dies off with a gurgle. We seldom see one, but they let us know they are there). Scarlet flowering Gold Mohurs (Poinciana Regia), purple Lagerstræmias, and yellow laburnum-like Cassias, the Pudding Pipe tree. These three latter are a gorgeous sight, covered with flowers without any green leaves. Then there is a lovely delicate Tamarind whose early foliage looks like grey lace. The sacred Neem tree is there too, with sweet masses of small white flowers. Bits of its branches are brought indoors sometimes and strewn about the floor when there is a plague of ants and other things. Also there is a Kuddam tree close to the house, in whose branches dwells a "bhoot," so say the servants, which causes ill-luck. This tree has quaint round balls of red worsted-like fluff for flowers, but I fear it will have to be cut down; not on account of the ill-luck, but because it is too near the house, obstructing our precious fresh air.

But oh! the Cork trees, the Millingtonia Hortensis, are my delight when they are in blossom. 
In the cold weather, from the tops of their elm-like heads, to the tips of their outermost branches, they are covered with drooping bunches of pure-white scented snowdrops; this is also oddly called the Tulip tree. It is good to string your hammock under one and lie there one fine morning inhaling its sweetness. Then if you close your eyes, and listen to the wind in the tops of the old Casuarinas, 50 feet high, you can fancy you are thousands and thousands of miles away from this "land of regrets." The sound is that of waves on a seashore, with the dash of the water on the beach, and the slow swirl of the dragging pebbles. How it makes one long to be there! I like the Casuarinas, though they are bad gardeners, and suck up all the moisture in the earth for some long distance round their roots, so that nothing can possibly live near them; sometimes in the early morning they weep it all back copiously like rain.

Another very favourite tree of mine is the Bauhenia. It has heart-shaped leaves, and a flower that comes out like a delicate mauve orchid with a sweet scent in October. I am glad they do not all bloom together, these trees; because then there is 
nearly always something to look for; but this is the month for most of them. Although many of them are deciduous, the garden never presents a real wintry aspect with all the branches bare together. The Jack trees and the Casuarinas are evergreen, but the purple-flowering Lagerstræmia certainly does seem to expect a rest, for it allows its branches to remain uncovered for quite a month. The Debdar of the country has more regard for appearances, and sheds its yellow fingers of leaves as fast as it possibly can; then long before the last are off, the first new ones are on; a most lovely green. In two or three weeks the trees are fully dressed; in two more the flowers are there; insignificant pale-green clusters, not pretty. And in July there are thousands of ripe berries for the flying foxes and squirrels. The Almond tree is pretty; before the large oblong leaves fall, they become a lovely ruddy tint. This tree is also one of those that studies "les convenances," and does not care to sit too long in its bones; for with astonishing rapidity it clothes itself all over again in green, before the last red leaves have fallen. The fruit of the almond tree is contained in a very hard 


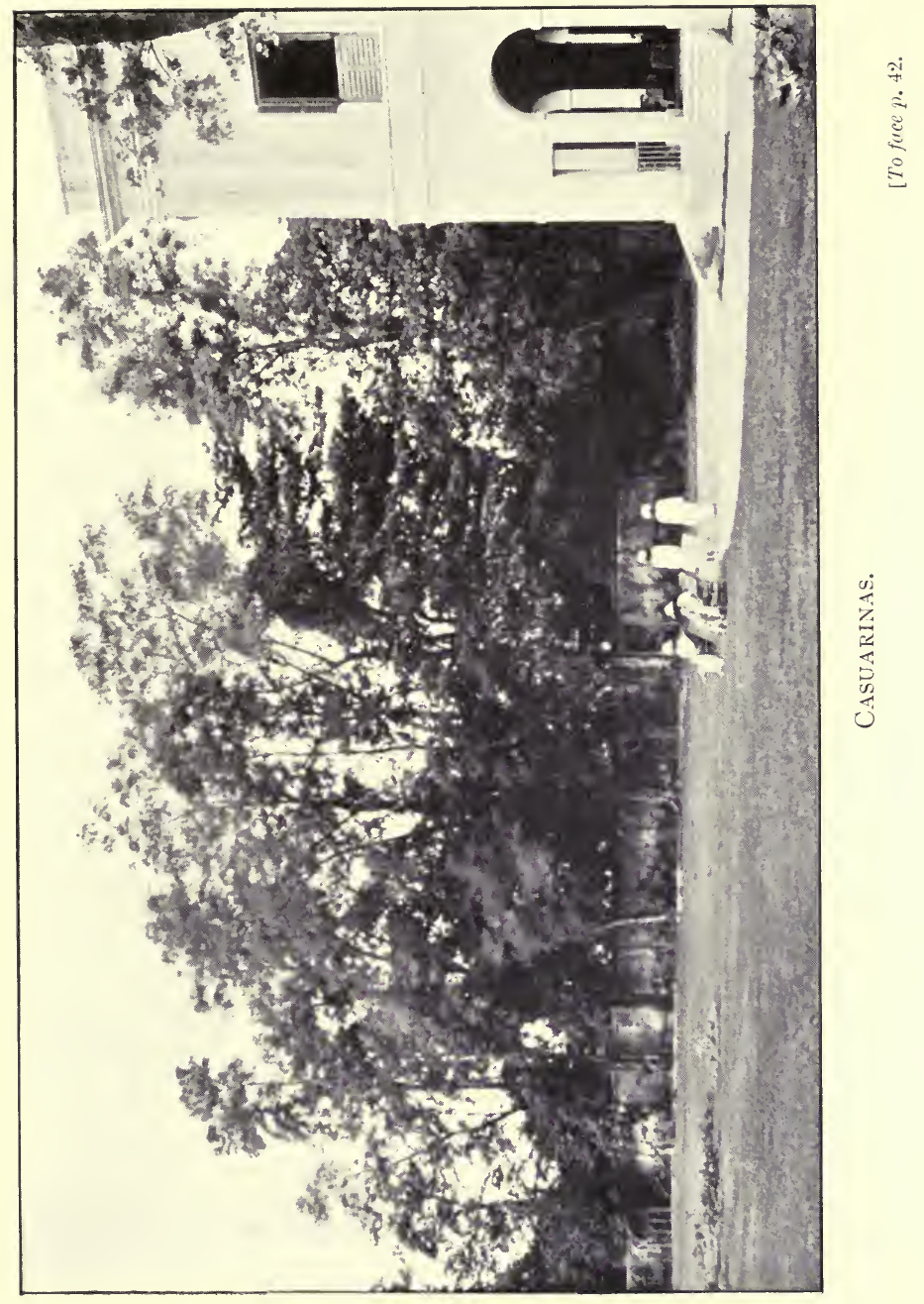



shell; so hard that we never can use the produce of our own trees on account of no one having the time to crack open the nuts. The kernel has a very sweet flavour. It is a most curious shape, like an inch square of white paper rolled tightly from one corner to the opposite one, into a cylinder. One unrolls it, trying to stretch it out flat, but it never can be done; it is so brittle that it breaks off instead, and it remains a mystery how it could have grown so perfectly rolled together, without adhering to the other folds.

The tree of all trees that would appeal to you, would be the Brownia; a handsome one enough without any flowers; but when twice a year, it flings out opulent masses of red and yellow blossoms as large as rhododendrons, it is a wonderful sight to see. Not only the branches are loaded, but the bark of the trunk itself bursts out in magnificent heads of colour; too large to be of any use on the dinner-table though, and much too powerfully scented. This tree has two seasons. It really is, when you come to think of it, very like some of us humans who also have two seasons; one here and another in the hills. The trees do not have the 
trouble of packing though ; they simply throw away all their used garments and start with everything new.

And that was what Unda also did. She went away after that great event in the garden, blossoming out into a new life; leaving me strewn all round with her dead "leaves." How inert and silent they looked the next day, lying about uselessly in corners ; no life, no grace in any of them. A bud was gone; detached from its parent stem; gone to begin gardening on its own account, in another GardenBeautiful ; dear little bud.

Besides the Debdar Walk, there is another shady one, that leads past the stables and the Chittagong fowl-house, round by the old pond, which is the abode of untouched jungle; for where are sufficient workers to be found to keep so much tidy? Even as it is, there have to be six, with outside help occasionally in addition. One old woman does nothing but sweep up leaves, and that keeps her well occupied all day; or rather has done till now. Past this pond, you come upon the portion devoted to cuttings, leaf mould, and pots. This is shaded well with trees, and surrounded neatly with a hedge of 
yellow and red cannas; a plant that we raved over five years ago, with flowers 6 inches across; but which grows and increases at such an enormous rate, that it is now considered common, and a great deal has to be rooted up and thrown away. I have planted a long row of them this year by the old pond ; scarlet, orange, and pink; which I hope will bloom well in the rains, as it is distinctly comfortable to be able to go and cut armfuls of them from the back-ground without robbing the front lawns, when sending flowers to the hospital.

In the afternoon the shade is best along by the west wall, under the Casuarinas and Cork and Almond trees; beneath which we planted a row of Kentia palms eight years ago, out of their 6-inch pots. These are now 15 feet high, some of them; and form shade the whole day, instead of in the afternoon only; because the fronds almost meet overhead with those of some Livistonias on the other side of the path, now grown to an enormous size from small table plants. High up above these, hanging in masses to the Casuarinas, are the purple Bougainvillia and French grey Thunbergia creepers ; and clinging close to the bark, is the curious cactus, 
the Moon-Flower, or Cereus Grandifloras; which blooms only after sunset in May. The flowers are very large, about 8 or 10 inches in diameter, with innumerable long narrow petals of pure white, round a cup-like calyx ; it is faintly scented. It is never open till dark, and then only lasts one night; by morning it hangs like a rag, so it is not much use; and one has to remember to take a lantern, and go and specially look for it at night, or one never sees it at all.

It is really a magnificent sight though, when seen by moonlight; the flowers in profusion all up the old tree-trunk, on which it clings without earth or moisture. It seems weird too, to think only night can produce such loveliness; and we feel a sense of loss, when in the morning sometimes we suddenly observe the limp, discoloured, brown bags that the flowers have now turned into, and we exclaim, "Ah, what a pity! we never remembered to go and look at the moon-flower last night!"

The Stephanotis and the Gardenia are out in May too; both pure white; and who does not know their fragrance? The Gardenia has grown to about $\mathbf{1 0}$ feet in height from a very tiny cutting, 
three years ago. It stands full out in the open and does not mind the sun; but the Stephanotis likes a little shade. This is all over the portico fern-house, which is north. Another pure white flower is out too; the Tuberose. Something shouted at me in the evening with its intense fragrance. I turned round and there it was; the first one open out of a long line. It is too strongly scented for the house, but I like it in the garden. Gardening operations now are limited to the Chamber of Horrors, for it is impossible to do anything outside; the sun is too fierce, and anything would die if moved.

Now is the season for Caladiums though; a near relation to our old friends, the "Lords and Ladies," of childhood. The bulbs have been lying in sand, and are now sending up shoots; asking to be planted out. The first thing is to prepare pots with good drainage; then a soil composed partly of leaf mould, and old bricks pounded up; and the rest garden-earth. One bulb in a pot is quite enough. Stand them in slight shade, and water well, and then watch them grow! The bright red one with green edges is the most 
common, but also the handsomest, when encouraged to throw up large leaves. From small beginnings I have now several hundreds of them; too numerous for pots, they are planted out all over the place, and give brightness to the arid borders. Another kind throws up its first leaf a lovely white, with delicate veinings of green, touched with red; but unfortunately the succeeding ones are not as good, and this kind will not do at all in the sun. Another sort will; a very large and much rounder leaf than the last, all mottled and shaded with lovely pink and pale green. Again a common sort has distinct spots of red on the green, as if touched with the tip of a paint brush. Another very large variety has dark crimson leaves, veined with green. There are many more, and the first leaves make a lovely show; and these are carried up, when well grown, and placed in the "Lean-to," facing the end of the verandah, where they smile at us at breakfast time.

Now this "Lean-to" is rather a triumph for me. I bought some odd pieces of iron at a friend's sale, that I imagined would just make a shelter for plants against an old disreputable-looking wall, 


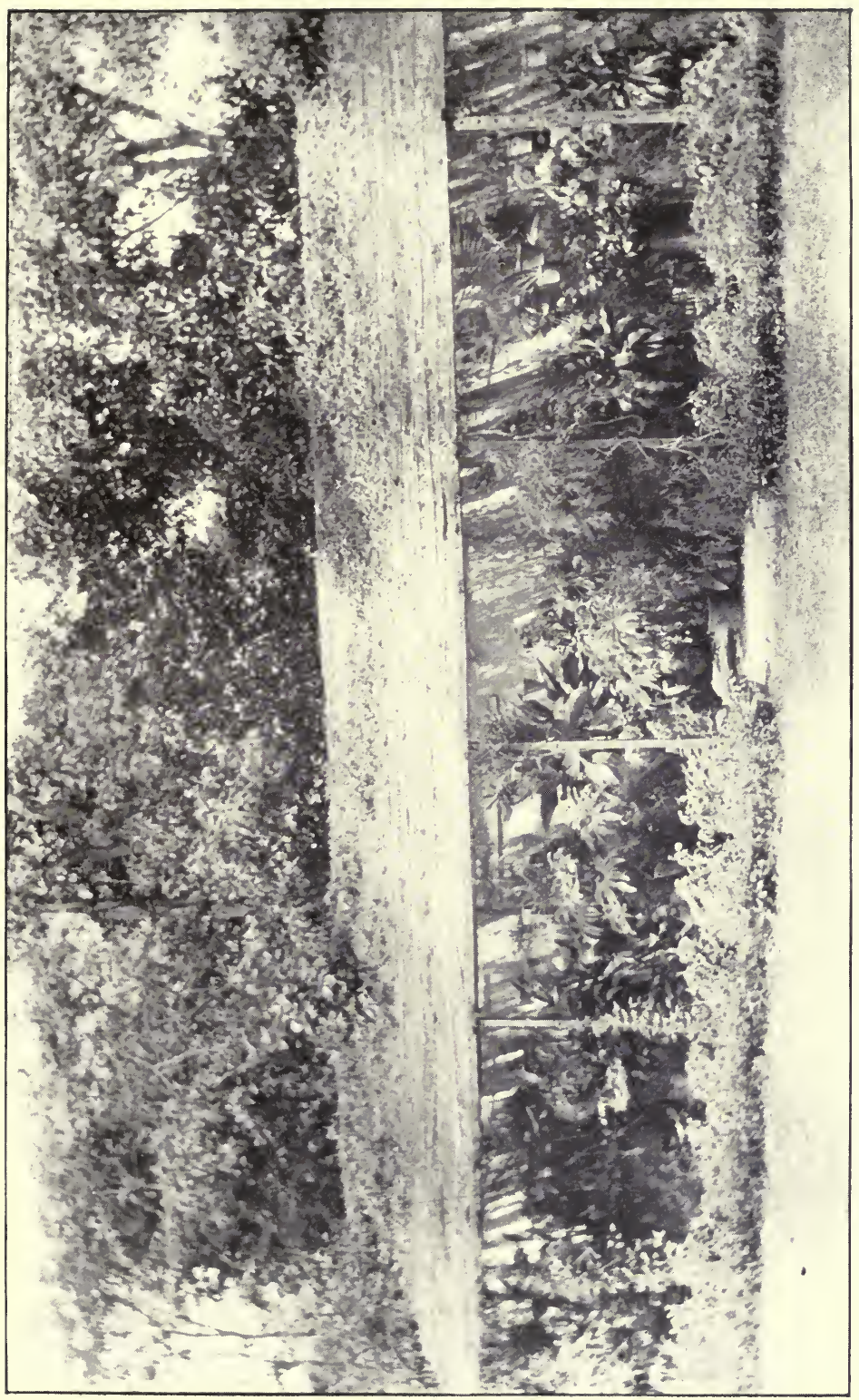

昰 

where a large creeper had been cut away; and which annoyed my eye dreadfully from the house. The Burra Sahib and the Ancient examined the bits of iron, and pronounced them useless, being of different lengths; so there they lay on the grass.

"Ah," I said to myself, "the Professor will be able to make them into a shed for me when he comes ; with a little cutting." He came; looked at them carefully, but said :

"No, I'm afraid it can't be done; there is not enough iron." So still they lay there unused, encumbering the ground; till one day I made some measurements and plans, and did it all myself, with of course the assistance of a Tubal Cain. We finished it in a week, and covered the wire-netting roof with thin layers of dried grass, and then ran about everywhere, collecting all the pot plants we could find with colour, that required only morning sun; till it looked ravishing. Caladiums, Coleus, Begonias, Amaryllis, Eucharis, Dracænas, Marantas, Dieffenbachias; all banked up in groups; and in front of the pots, a row of black edging, which effectively showed up the colours above. Up the iron supports were wound trails of Cissus, 
with its rich dark velvety leaves; and Lycopodium that turns a beautiful electric blue in the shade. Between the iron pillars gently swayed maiden-hair ferns in baskets, with pendulous creepers and dwarf Pampas grass. Now does not this sound successful? Of course it was an experiment at first, and one had to wait and see if the plants flourished in that situation, facing east and partly shaded from midday sun; but I have found that it is extremely good, for all those I have named. By having only pot plants here, renders it possible to keep up a succession, by removing those that are over and substituting others. Here I have brought the best of the orchids when in bloom. Frides, Dendrobiums, Saccolabiums, and some other hardy kinds that grow without glass; and the Burra Sahib really does admire them while enjoying his breakfast on the verandah. He even does not mind being crowed over!

Strange to say, I have not seen a single snake here since the creeper was cut down. Before that, several were killed hereabouts. I think they must live in between this wall and that of the next garden, which are separated from each other by 
about the width of a brick; a favourite sort of abiding place for cobras. Just where the present "Lean-to" is built, there used to be a small pigeon house, enclosed with wire netting to keep out civet cats (which it didn't). One day in May, like this, the morning sun being very hot, we placed some large dried palm-leaves in front of the netting to render it cooler inside; as I was also rearing some young ducks on the ground floor, below the pigeons' shelves. One morning after, I was standing outside, close to these palm leaves, when I suddenly heard a rustle amongst them; just on a level with my face. I could not see what it was caused by, and felt inclined to part the leaves, and look for a possible lizard or a chameleon, but did not, luckily. How little did I dream what it really was! In a minute or so I went off to the portico fern-house, and sent a man to bring me a plant that was standing by the pigeons' house. He came running back in terror.

"Big snake!" he cried, "very bad snake, black one." He said that it was sliding along the grass towards the little ducklings, who were nestling in a bunch together on the lawn; when, as it saw him 
appear round the corner, it raised its head, extended its hood, and hissed at him; then turned up the ivy-covered wall and disappeared over the top in a second. Only a few minutes had elapsed since I had stood there, and that must have been the cobra rustling in the branches of the palms, lying in wait for one of those little ducks. Suppose I had stretched out my hand and got bitten! as I most assuredly would have been; it was a very narrow escape, and only averted by the small accident of having to hold an umbrella in one hand, and a gown in the other. The dogs went with me as I returned to the spot, and then to see their excitement! They had found its trail, and this way and that way, with their noses close to the ground, they scented just in the place the man had pointed out. It is always distinctly evident when they are scenting a snake, by the sinuous curves in which they run; and a peculiar bark announces when they have found one. Nous does not always bark when he sees a cobra. I have been present twice when he has caught one. Each time his attention was attracted by the other dogs barking round a small tussock of grass, through which I 
had nearly walked. On arriving Nous took one look, and like a flash, darted in and brought out a black writhing snake. It was only by following him up as fast as possible that I could know what kind it was, for he always gallops off with it in his mouth to the opposite end of the garden; the other dogs after him, eager to assist; and they have a tug of war with it; literally tearing it to pieces. Their panting excitement over a snake is terrible. No one can ever stop them if they once catch sight of one. On each of these occasions I found the spectacles clearly defined on the expanding hood, and the cobra is the only snake in the world that possesses that mark.

There was a third most exciting episode : when the four dogs all together caught a very large one in the pathway, close to the double wall. There was some tennis going on a little way off, and I was rather distracted by the constant barking of the dogs, at a particular spot in the gravel walk, and went across to stop them. One of them bounded to meet me, and excitedly escorted me to the place as much as to say, "Do come quickly!" I found Nous scratching like mad at one side 
of the path, and Poppy at the other, while the two others were barking their loudest, and galloping round them. There was evidently a hole underneath, and something in it; probably a rat; or perhaps a civet cat; for as I bent down and listened, I could hear a curious noise like a cat's swearing or hissing; something like a kettle boiling very fast. By frantic scratching and biting of the hard earth with their teeth, the dogs had narrowed the space between them to about one foot, and I could see a small tunnel opening on each side, but could not see through.

"Whatever can it be?" I asked some of the servants, who were holding teapots, and plates of bread and butter in their hands.

"It must be a janour," they said.

"An animal!" I knew that before, but everything with them is a "janour." Anyhow the noise must end, so I took up a twig from the ground, and inserted it into the hole nearest me; Nous obligingly making room, knowing perfectly well why I did it, and joining Poppy, who was glueing his nose to the other end. I just shook the stick about for an instant, when Poppy seized the end of 
a tail, and gave a great tug, and out came a snake! To my horror, I saw that, as its head emerged, undulating in the air, it expanded its awful hood, and there it was, a great black cobra! In an instant Nous seized it also by the back of the neck, where he always does, before it had time to strike, and off they flew together with it; their teeth closed fiercely on the terrible creature; one at the head, the other at the tail ; right into the middle of the tennis.

"Take care! take care!" I called in a fright, "it's a cobra!" I was dreadfully afraid Nous might after all have been bitten, and we hurried off to find him, as they had dashed right away out of sight. The first thing we came upon was the cobra's head, bitten clean off with a part of the neck, lying there, actually even then opening and shutting its mouth. So the grip of Nous' teeth had been very severe. When we came up with the dogs, they were frantically wrenching bits of the body from each other, evidently determined that the destruction of the rest of the animal should be complete. Then Nous went down into the water and bathed the snake's blood off his body, and 
came to receive the compliments of the company. He did not appear to have had a bite, but I watched him for the next hour, as he lay resting with an expression of intense satisfaction on his face. Nothing however happened, and it was a wonderful escape. We never can prevent him from going after snakes; no calling will stop him and I very much fear some day he will get bitten, when of course it will be certain death in fifteen or twenty minutes.

If we could only get rid of the snakes; but how? We are not sure that they are between the walls, and nothing can be seen of them by looking in. I only know that that is the quarter in which they prowl; along a range of go-downs. One came into the washerman's go-down once. He sprang up on the ironing-table, and the venomous thing sat up and hissed at him, and then disappeared down a hole in the wall. We speedily bricked that hole up, and there it may be now perhaps! Another time, old Grey Beard saw one in the kitchen in the early morning, with its head in a saucer of milk. It is not a nice idea; cobras in the kitchen, lapping up the milk! 
In more remote times still, the Burra Sahib shot one that was coiled up in a dusky corner, hissing at the dogs, when Nous was a puppy; and before he had taught himself this trick of catching them by the scruff of the neck. Again, another time he shot one that had gone under an arch beneath the verandah, in the evening twilight.

The first time I became personally acquainted with a cobra, was one sultry evening about dusk. I was sitting on the lower verandah, near the top of a flight of stone stairs leading out on to a gravel walk, when I suddenly became aware of a dim, dark thing moving slowly along the lower step. Then I saw it was a snake. I called out to Chota Sahib, who was in his room close by.

"Bring a gun C. S. ; oh ! quick, here's a snake." I was afraid it would disappear when it heard the sound of voices; but no, in the other corner of the step it silently, slowly swelled up, and over without any apparent movement, and up the next; taking no notice of me at all. As C. S. brought his gun, I ran into the dining-room for a light, so that we should be able to see where it went. The only one there was a great table lamp; but I seized it H 
with both hands and carried it out, just as there came the report of the gun. C. S. said the snake had risen to the very top step as he came out; the instant he pointed his gun, it saw him, sat up with hood extended, hissed and turned back over the parapet into the cemented drain; and there he shot it. Another cobra! There were the horrid spectacles; proof positive of its deadliness. C. S. must have been very quick, for snakes disappear like smoke when alarmed.

"Where could it have been going? Where did it live?" we asked each other. It was an awful idea to think it might have curled up my basket chair, or come straight indoors, and we might never have seen it in the dark. For several evenings I could never sit down to dinner, without first having a lantern fetched, to search under the table, for possible "sudden deaths" on the carpet. Fancy putting one's feet on what one imagined was a hassock, and it turned out to be a cobra instead! Or like a man, some time ago, walking in the middle of the road at night, who saw something black lying there which he thought was a cat, and gave it a push with his foot; then walked on. $\mathrm{He}$ 
looked back and saw it had not moved, and he actually went back and touched it again; when it bit him, and in twenty minutes he was dead. It was a huge cobra coiled up, slowly swallowing a frog it had just caught. Mem. :-Never kick a black cat in the dark.

Visitors sometimes, on being asked out to sit in the garden, look round them suspiciously, and say inquiringly, and with a threatening look, "No cobras!" as if they thought we kept them as pets, and might be going to play tricks with them. I have come to the conclusion that snakes also live deep down among the roots of old trees, for that is where we have seen many; whenever a tree is cut down and the roots dug up, snakes are found; mostly harmless ones; either the little striped grass snake or the large 7 -foot rat snake. One very old tree-stump disclosed a nest of tiny Russells' vipers, which are quite as dangerous as cobras. The rat snakes do no harm, but the Burra Sahib gave out an order.- "Kill every snake you see!"

So it used to be no uncommon event to see every man in the compound seizing sticks, spades, rakes, whatever they could catch hold of, and flying 
with arms and legs in the air, whenever the dogs gave the warning, or whenever a snake was seen by anybody; no one waited to ascertain if it possessed poison fangs or not. "Kill! kill!" was shouted by mild Hindoo and gentle Mahommedan alike. No one seemed to think of caste restrictions against the taking of life, but one and all were imbued with the spirit of the chase; or was it the master's reward of 4 annas a snake? Thus the place is much clearer of them. But the pace at which these reptiles go is amazing. The dogs often used to turn one out in front of me as I went round the garden about midday. A very long rat snake I raced as it slid along by the wall. There was some fascination in trying. who could go the fastest; but it was rather gruesome when it hit out at me with a sudden swish of half its body, and though I knew it was a harmless kind, I came to a full stop pretty quickly, with a shuddering, irrepressible "Oh!"

The largest that has been killed here is 7 feet 10 inches long, and we had it stuffed and hung up in the Professor's room; waiting till he came out from England. 
The Ancient came home at dusk on the day of this last snake-killing exploit, and was shown the body. It was in perfect condition, as only the head had been beaten with sticks, the dogs not having been there.

"It would do for a lady's boa," he said.

"Try it on," said C. S., and so he did, to the huge amazement and wonder of the servants.

"I think those boys would like to see it," he said, meaning the "ducky" chummery.

"They say they have never seen a snake, and made me promise to send over the next one we killed. I fancy they don't believe we have any."

"Do take it over," we said, "this is such a big one."

"I will go as I am," he said, and off he went with the great creature coiled round his neck, and dangling down his sides, out into the road; frightening all the passers-by into fits. By-and-bye he returned, choking with mirth. He said he found no one at home at first, so he sat down and waited on the verandah. Presently one came in when it had become quite dusk. He rushed up the steps saying, "Hallo! old man, I haven't 
seen you for an age!" and promptly fell upon his shoulder, putting his arms round his neck in the chummery's usual playful way. When his hands came in contact with the cold snake, he leapt about 3 feet in the air, and with lurid language, inquired what he had got there. The Ancient explained, but he was unable to repeat to us the remarks made to him, and he brought his boa back, well pleased with the result of his little trick.

About this time the Ancient had his own little cobra episode all to himself. He had often wondered how and why the youngest pigeons so frequently disappeared during the night; and got up very early one morning to try and find out. The first thing that met his eyes was a large cobra with his head through the wire netting, making frantic efforts to get through; which the pigeon he had swallowed effectually prevented him from accomplishing. Here was an opportunity not to be missed! Indeed it would have been very difficult to miss it, with the stout stick he had in his hand; the situation was made the most of, and the cobra was added to the Ancient's bag.

May is the time of the mango harvest. This is 
the most luscious of all Indian fruits and almost the most abundant, with the exception of the homely plantain, which, like the poor, is always with us. It comes in the hottest month of the year, as if to compensate us through the palate for the miseries inflicted on the skin ; prickly heat, and such-like. With our nine trees, we sometimes have a very large crop; not so this year; the bloom was excessive in February, but high winds last month blew off a great deal of the tiny fruit just forming. Then they have other enemies; squirrels, crows, and monkeys. Two of the latter, a pair of great brown Langours, living about in the jungle, come every day along the garden wall, swinging themselves up into the topmost branches of the best mango tree, where they sit defying everybody, and breaking off the choicest fruit and eating it before our eyes. The dogs nearly choke themselves with wrath, and so do we, standing underneath. Jogee and Poonia and their men hurl stones and abuse at them, none of which affects them in the least. The largest one is about 5 feet high, if standing straight upright, and he sat there in the tree last week, calmly munching his mangoes and throwing us 
down the stones; caring not a pin for Jogee. When a stone came rather near, he watched it and ducked his head; then changed his position, crossing one leg over the other comfortably, and continued eating. He treated me with the same contempt, though I waved a large white umbrella at him, frantically jerking it up and down as high as I could reach. Suddenly looking over his shoulder, with head stretched forward, he stared intently through the leaves at something in the distance. What was it? A white mushroom hat advancing nearer and nearer; and under the hat, a gun.

"Go," I said, trying to reach him with the carriage whip.

"Go," said Poonia, nearly touching him with a long bamboo.

"Go," cried the others, with showers of stones.

"No, don't go," said Jogee, sarcastically. "Wait and see, someone cometh, and he will punish evil-doers."

The monkey gazed and gazed till the hat and gun were near enough; then he took one flying 
leap from branch to branch, touched the top of the wall, and was over it and out of sight. It is $\mathbf{1 0}$ feet high, so we could not see where he went. Jogee triumphant.

"But," I said, "how should he know it was a gun?"

"He knows everything," said Jogee. "He is an all-knowing one."

"But you like monkeys," said I; "you have a monkey god. You would not kill one, surely?"

"I would," said Jogee, "if he killed me."

But the master was only intending to frighten him. He said he would never shoot a monkey. Whoever did, would never do it again. Its cries are quite human.

I advised Poonia now to go up and gather the ripe mangoes, or we should have none left. Poonia is tree-climber to the establishment. Whenever anything is wanted, flowers or fruit, from the top of a tree, he it is who always goes up and fetches it down. With the exception of the tail, there was not much to choose between him and the Langour, as he walked about among the branches, throwing down mangoes. Jogee and the red-hatted door- 
keeper held a sheet to catch them in. It was difficult for Poonia to aim straight through the leaves, and these two had to display a very unoriental-like agility, leaping about with the sheet, to prevent the mangoes falling on to the hard earth ; and it was hot work, and thirsty. However, they had some mangoes for themselves.

I almost wonder Red Hat did not say :

"I was not hired to run about with a sheet catching mangoes," as Canary did about the ducks; but I very seldom hear such a remark as that; though it is a most common excuse among Hindoos, when they receive any new order. The last Red Hat, some years ago, objected to carrying some pots of plants about for me. The air of disgust with which he looked at his fingers after lifting one, annoyed me, and I said :

"There is no harm; if it does not hurt me, it won't hurt you."

He said : "I am a poor man; my father served the master for eleven years in his office, and never was he required to lift any flower pots."

"No matter," I said; "it is possible that the master may not have desired to have pots lifted. 


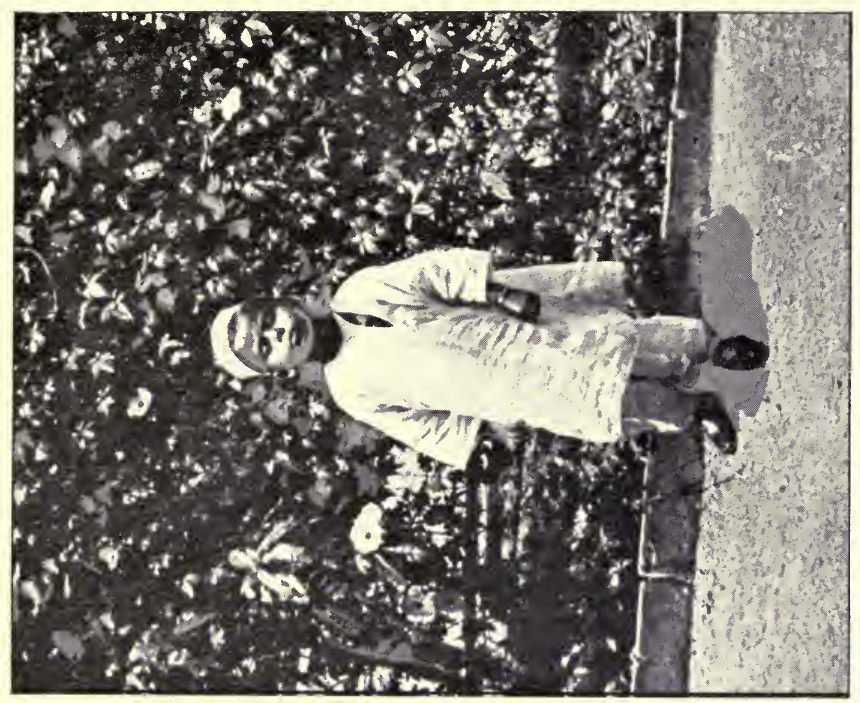

焉

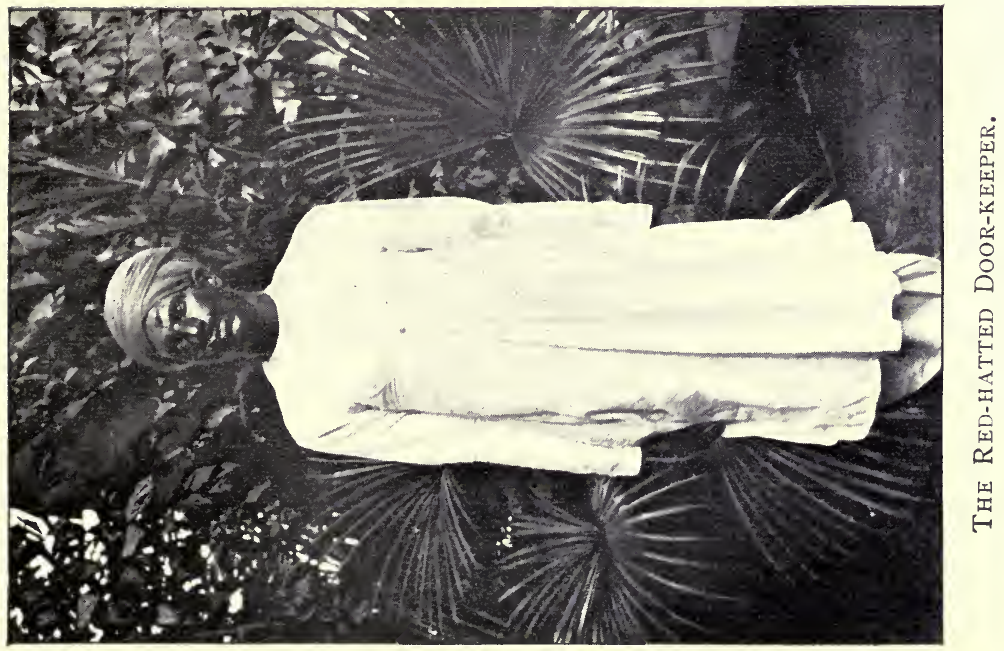



I do, and it is better that you should attend me, and do a little work, than sit all day on a box by the gate." In the evening, however, he came to me with tears in his eyes, and said:

"Your honour is my father and my mother, and I eat your salt; but I can lift no more pots. If the Red Hat living near by at another house were to see me, he would excommunicate me. $\mathrm{He}$ is the priest of the Red Hats."

"Very well," I said, "if you would rather listen to him than to me, do so; but I shall be compelled to have a new Red Hat, one who will make himself useful;" and the present one arrived, and is an extremely good man. It took some days to finish this work, and then chutnies and preserves were the order of the day.

I really think it is dangerous having these monkeys about. One never knows when they may drop down from the trees on one's back. I saw the big one reach down his long arm from the wall and box Klinker's ears, making that estimable dog fly for his life. So I gave a broken air-gun to a coolie boy, and told him to point it at the monkeys whenever he saw them, which he did with the 
greatest success. So now he goes about among the others with a triumphant grin, and considers himself quite a sportsman. A Langour, up-country, once took up a terrier and tore it in two; and another ran off with a native baby. When the crowd pursued him, he rapped the child's head on the ground and killed it; so vicious are they. I hoped these would disappear when there were no more mangoes to steal, but now they come for the guavas. So we are obliged to gather them in before they are ripe.

Some years ago when Klinker was a baby, he actually caught a Gecko. It was very funny to see him running along with it in his mouth, the animal as big as himself; and the long lizard-like tail dragging on the grass. Klinker deposited it on the ground for a little rest, and the Gecko feigned death ; but when Klinker looked at us for approval, the Gecko made for the water, and was gone in an instant. Klinker sat on the bank, perfectly still for a quarter of an hour, watching the water, and no doubt feeling a very foolish dog. He looked one.

I have never been able to discover if the Gecko 
and the Bis-cobra are the same. Some say they are, and that they are more deadly than the cobra. They would have some difficulty in being that, however. I very much wanted to see one when we were at Delhi once; the Burra Sahib and myself. We were staying in the Hotel that is built on the old wall, and we were the only visitors the first day. After dinner we sat in the drawing-room with one small lamp on a table, in the middle of the room. This only threw a halo of light just round us, leaving shadows everywhere else. It was very quiet, and suddenly as I sat writing, a sound came as of scratching in the ceiling; then something fell on to the floor, narrowly missing the top of the sleeping master's head. Exclamations brought another lamp and the landlord, and search produced two grey lizards lying perfectly flat on the floor. They recovered though, and were off in an instant, and the landlord smilingly assured me they were quite harmless, which I knew. This caused me to begin questioning him as to what other kinds of creatures he might be likely to possess; living near ruined bricks and mortar as he did. 
"Have you any cobras?" I asked.

"Oh yes," he said, "many."

"Really," I said, much interested, looking round at the shadowy room.

"Also," he said quite proudly, "we have the Bis-cobra."

"The Bis-cobra," I exclaimed, "I have never heard of that, whatever is it?"

"Oh," he said, "it is like a large lizard, and its bite is very poisonous. One was killed here in this very room four days ago," with a smile.

Heavens ! the man thought he was pleasing me by this account of his reptiles. I said I would go to bed at once, and have as many lamps in the room as there were corners. We did, but the light was so bright I could not sleep. When at last I dropped off, I was awakened by most curious scratching noises. I shrieked to the Burra Sahib that there was the Bis-cobra trying to get in! Which side, and where? I pulled the mosquito net tightly in on all sides, as if that would be some protection, and gazed horror-stricken all round. Would it make for us open-mouthed at once, or could we fight it? The master seized his stick 
near by. The scratching noises then located themselves on to the side table, in a card-board box.

"Oh," I said, "it's only the locust! not a Biscobra," and I went and opened the lid, and peeped in, and there was my locust that we had caught at Jeypore, out of a large cloud in which we had been smothered, and intended sending home to the Professor. It had just woke up, and was trying to eat its way out; and that was all I ever heard of the Bis-cobra. We did get the locust home to England all right, but not alive. Its appetite was enormous. It finished off half a pear in a very few minutes; but it died, and was added to the butterflies that I had been collecting. The Burra Sahib was so good as to take me out long delightful drives into the jungle, sometimes, in those days; and then for hours, two white mushroom hats, and two green long-handed nets would be seen, madly rushing about after the beautiful peacock, brown velvet, sulphur and white, and swallow - tailed butterflies, whose names I know not; but which were to be a joy to the C. S. and the Professor in embryo ; the collection of which was their particular craze just then. What enjoyment there was in 
those days! when they all looked to me to share their pleasures. Alas! they have all out-grown their crazes, and are solemn, respectable people of science and learning now; while I who ought to feel old, cannot. This garden is full of those same butterflies, but no one even looks at them; and their former admirers are all scattered about, hundreds of miles from each other, and have left me on the shelf, solitary. 


\section{JUNE}

"The land

Shimmered with heat, and walls and temples danced In the reeking air."

Enwin Arnold.

Such joy! the C. S. has come to stay again. Now I shall have some one to potter about with in the evenings, instead of taking that usual monotonous drive. Directly he comes, something new always begins. The garden, though, is not much use just now, with the thermometer in the shade at 108, as it was one day this week. It is some credit to groaning humanity to be able to acquire an evening cheerfulness, when all day long existence has been a burden, tormented by prickly heat, mosquitoes, and blistering clothes on one's back. The dogs move restlessly from one spot of paved floor to another, finding none cool; even a foxterrier's coat is too thick for this weather. What can a "Chow" or a woolly-haired dog feel like? I 
would not keep one in such heat as this for anything. I know two or three dog-owners who send their animals up to the hills every hot weather, even if they stay down themselves! As for the horses, it seems most cruel work to make them drag carts and carriages; but how else are the masters to get to office, 3 miles away? It must be done; but the poor animals pant and hang their heads for hours when they get back. Horses are falling everywhere, but so far we have managed to keep ours fairly well, by turning them out under the trees to graze in the afternoon, instead of standing them in a hot stable all day long. Horses, dogs, and ourselves, all are waiting and longing, with tongues out, for the Rains. Every day we anxiously look for the little cloud in the South, which ought soon to rise over the molten sky, and bring us and the whole earth round us relief.

"Only one more week," I remind the Ancient, who with palm leaf is trying to stir the turbid apoplectic air.

The Ancient murmurs, "An ice-cold dinner from start to finish, even to the soup."

I gave it; last night everything was cold as an 
iceberg. The soup was a jelly. The vegetables were iced. Somehow it was not a success. It was partaken of in weary silence. Convention is everything, even in such heat, and cold soup does not look appetising.

" Oh man of many clothes!" I say to the Burra Sahib.

" "Futile Fopperies, unnecessary wraps," I shout at the Ancient, as they both appear in the same identical kind of high glazed collar, and with sleeves to their coats. The temperature is such that even woad would feel superfluous. How sensible it is of these natives to garb themselves in loose white muslin! I implore the Burra Sahib and the C. S. to allow me to take out the sleeves of at least their undergarments, even if they retain those of their coats. To see them wearing double pairs of sleeves when I can endure none, fills me with pity for them. To rest the tips of one's fingers on a black cloth arm in June, is as unpleasant as touching a "burr." How much more soothing would be the look and feel of soft oriental satin, say black if they preferred it, lined with the thinnest of silks, and instead of the stiff starched collar and 
polished front, a soft neckband and "jabot" of lace. Knee breeches and silk stockings would more fitly encase their lower limbs, too, for at any rate eight months in the year in this climate, than the thick formless articles of cloth now worn, while the gain in becomingness would be immense. The whole turn-out could be achieved for the same outlay as the present hot and un-hygienic style. Thus I argue with them all.

"No," says the Burra Sahib. "I am going to have a sleeveless blouse."

I wonder how many people sleep on a June night just before the rains. Some there are who can sleep through anything, lucky beings. I only know my own feelings, and that is, that a June night is an utter realisation of the biblical description of the tortures of the damned. After a day of intense heat and misery, induced by the necessity of wearing clothes, one at last tears them off with a slight feeling of relief, and a hope of being able at once to drown one's sorrows in sleep. The first contact with the pillow, makes one imagine it has just been taken from before a scorching fire; as also everything else that is touched. The eyes 
close though, and if nothing disturbing happened, there might be oblivion for a while. "Ping" goes a mosquito with his trumpet nose. He has found his way into the net, and he circles round his victim, shouting his threats, till he settles on face, hand, or arm, his little lance thrust into a sensitive nerve. The sufferer turns and tosses, till bed is like a mustard leaf, the heat growing in intensity, while every pore of the skin glows and rages with prickly heat. A walk is taken up and down the verandah, and perhaps a sponging with the tepid water from the bath (cold water there is none), and then another endeavour after slumber. This time one's eyes get fascinated by the frill waving over head. From Presto at the start, it has now gradually become Largo. A shout of "Pull," jerks it along again for a few bars, but not enough to soothe one into a deep sleep, wakes one with a start; all bathed in perspiration, and tingling in every pore. Oh! for electric fans! I regret to say slippers or tennis shoes in showers have sometimes descended on to the sleeper's head below; that being the only known means of rousing him to his duty, except the contents of the 
water-jug, which he has been known to render innocuous by sleeping under an umbrella. When a punkah-wallah is newly engaged he takes care to begin well, and it was "once in May" that the Professor first slept under one, after having steadfastly resisted through several sweltering nights. In the morning I asked him how he slept. "Ah," said he, "it was lovely. I felt as if I could crawl down the rope and kiss the punkah-wallah!"

Once when he was very young the master cautiously descended the stairs to interview the sleep-robber, for another purpose than to kiss him. With one slipper on his foot and the other in his hand, he slily crept along the verandah; but the punkah-wallah saw him coming, flung down his rope, bounded over the rails out into the garden, and fled through the gate like a deer; the master ran after him, up one street, down another, all in the dead of night, but he didn't catch that miscreant. $\mathrm{He}$ had to return after this midnight exercise in his night garments, a hotter and a wiser man; and now when chastisement is necessary, he wakes up the door-keeper to do it for him, which is more 
effectual; except in the case of the punkah-man being own father to the door-keeper, when no amount of commanding will induce him to beat him. He only smiles foolishly at him, and respectfully asks him to pull.

I wonder if you will believe a true story of a Man, a Lady, and a Punkah-puller? It was at a boarding-house where each person's room, protected with a purdah, opens on to a long verandah. Here sits the coolie connected with each room. Man (young) arrives home late at night from a party; every one in bed and asleep. Looking through his purdah when ready for bed, he observes his punkahman conspicuous by his absence. In fact, he is not there. It is too hot to go to bed without a punkah, but how to find him in the middle of the night like this? Who knows where a punkah-man lives? No servant about to go and fetch him. Finding he does not come and fearful of disturbing the house, he softly approaches the next door punkah-man, sitting in front of the room of his mistress, the Lady. Man whispers, "You go downstairs and fetch my punkah-man, and I will pull your punkah while you go." Fatal act! 
Treacherous punkah-man takes the opportunity of snatching a pull at his hubble-bubble in the intervals of looking for his brother, and does not come back at all! Man gets deadly sleepy after losing already half his night's repose. Lady (also young), calls out "Pull!" Man wakes up with a jerk and pulls madly for a minute; daren't let go, or say a word; then his head sinks again, and the rope goes slack. Lady rushes out from behind curtain and slippers the drooping back of supposed punkah-man, who springs to his feet. Tableau! Shrieks and hurried exits, R. and L.! But to return :-

A third attempt at sleep is made, and now begins the horrid native "tom-toming," in honour of some wedding in the village. The tune consists of one long note, and three or four quick ones; all of the same altitude, breadth, and thickness; the only variety is in the time; one long, four short; one long, four short; the thumb of one hand and the fingers of the other, on the same identical spot of the parchment; and it goes on thus all night, for a week. There was one dreadful fortnight, when it continued all day, as well as all night, with 


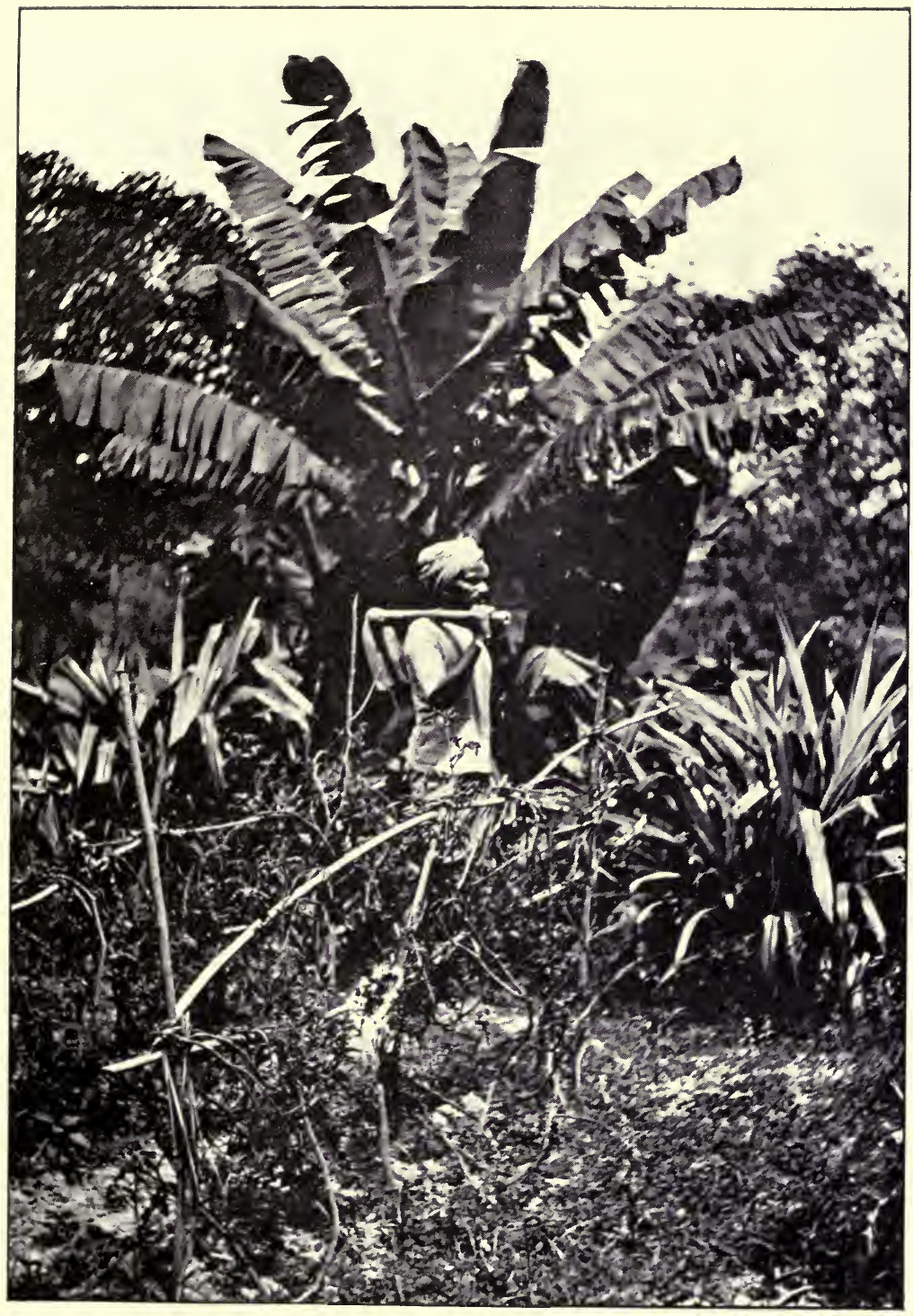

A Coolie among the Plantains. 

relays of performers; till madness seemed the next item on the programme. When this is not going on, the native pariah dogs yap, several of them together; so fast and shrill and with such intensity for hours in succession, that one wonders why they don't fall down and die, out of sheer fatigue.

Soon after this come the jackals, but they are a welcome relief to the ear, after the irritating monotony of the tom-tom and the dogs. They come in from the jungle, swarming along in packs in search of food. As they come by, the leader howls out in a high voice, "Dead Hindoo-0-0-o!" dropping his voice slowly on every $O$. The next one takes up the refrain, "Where? where?" several notes higher, and well sustained. "Here! here!" screeches the third, in the shrillest of trebles; and then the whole pack bursts into a demoniacal chorus of yap-yappings, howls, and barkings, which gradually grow fainter and fainter, till they die off in the distance. On a moonlight night in addition to these, the brain-fever bird sits and cries all night till dawn. He begins on a certain note, and gradually shrills it up and up like a scale; till you wonder when he will stop. On the topmost note 
he shouts with the voice of a ship-siren:- "Brain fever ! brain fever !! brain fever !!! brain fever !!!!" till night seems more hideous than ever.

But why the native policemen should be allowed to yell to each other, at any and every hour of the night, and connect their beats with a chain of howls, beginning on a high note, and slowly descending till they have expended the very long breath they inhaled, is one of the things I cannot understand. As if all this is not enough to plague a wakeful person, when every sound seems to cut into the brain in the deadly stillness that precedes the rains, a goods train appears to lose itself near here every night regularly. At any rate it stands and whistles, with a most ear-piercing scream, in the shrillest of penny fifes; not once, but many times. Whether it is endeavouring to awaken the pointsman, or the signalman, or is merely letting off steam preparatory to going to bed, I know not. The last aggravating sound (though I haven't mentioned owls and cicadas) is the siren belonging to some ship about to sail with the tide, which sometimes even as early as half-past two, thus seems to assemble its captain and crew preparatory 
to making a start; but neither of these last are as diabolical as the tom-tom and the dogs. After the first thunder-shower, when the rains are near, the great yellow bull-frogs come up from the bottom of the mud in the pond, and they sit all round the edge of the water, with their noses just out, and bark like Newfoundland dogs. Once the master and the C. S. were so kept awake by them, that they got up early in the morning and shot all those bull-frogs ; since when there has been peace in that direction. The other annoyances are not so easily disposed of. One can't shoot a policeman or a tom-tom.

15th. "The Rains!" Oh! the blessed rains! at 5 A.m. true to date. I rushed out on the verandah to see them come down like the water at Lodore. The temperature was instantly lowered 30 degrees from that of yesterday, and how delicious was the smell of damp earth and wet leaves! The red-hot roofs absolutely hissed as the heavy rain-drops struck them. Up now will go all the drooping heads of man, beast, and plant; long may it last, we pray; not come and tantalise us with a mere show, but rain for days and days, with just 
an interval for getting the master to office and back!

"How beautiful is the rain!

After the dust and heat,

In the broad and fiery street,

In the narrow lane,

How beautiful is the rain!"

Another joy! I have given away half of Penelope! At least, a friend is going to divide him with me; so that now I shall have two weeks' reprieve in each month, without having to invent tasks for him, on days when there are absolutely no ravages in the laundry linen to repair ; and now C. S. and I are going to start at once on roadmaking, culvert building, path alterations; and grandest of all, a large new fern-house facing north, which he is going to build himself from his own design. According to the plans for this, I shall want about 2000 pots to fill the stands! What a business it will be preparing them, but now that the rain is loosening the earth, one can do anything. These will be grand growing times, and I must take up and divide the ferns of all kinds that are growing under the south wall, which will give me ample for my fern-house. There they will do much 
better. Counting the wild ones with the tame, I have 95 varieties. There are nine kinds of Adiantums, from the dwarf Victoria to the largeleaved Magnifica, Lastreas, Aspleniums, Blechnum, Polypodium, Pteris cretica, and the lovely silver and gold ferns. Intermixed with them are four kinds of Selaginella which I used to treat respectfully at home. Here I sometimes have to throw away bushels, when it has become too thick. They all grow and flourish here out in the open, during the rains and the cold weather, but look rather seedy in the hot. I made this long double bank, in tiers, with the blocks of old concrete roofing that had to be taken down off one part of the house during the repairs after the earthquake a few years ago.

That was an experience that one does not easily forget. On the very first day of the rains it occurred. It had rained all day, just ceasing about four o'clock, and as usual I at once wanted to garden; the soft earth looking too enticing not to plant something in it, when one knows at what a rate things will now grow.

"Poonia," I said, trowel in hand, "fetch me 
some of those red Calladiums from under the mangoes."

He went. I stood still, considering my plans just outside the verandah, close to the Kuddum tree, under which was arranged a rockery; how clean and sweet it all seemed after the rain! I was enjoying the scent of the earth and grass, and the relief from the overpowering heat, when suddenly there was in my ear a sound of a loud rumbling over away to the north-east. I hardly formed any idea of words in my thoughts, but it flashed through me, that that was an unusual sort of kettle-drumming among the soldiers in the lines. It was something like a train in a tunnel, but muffled. A second after, I found the ground heaving beneath my feet. I toed and heeled involuntarily, as one does on board ship in a choppy sea. Then I became aware that this was an earthquake. I looked at the house, and saw it was swaying from side to side, with a rocky sort of motion; and from within came great crashes of sound. Then I remembered Unda was upstairs, practising her violin.

In an agony I called, "Unda, Unda!" She came to the verandah rails, waved her arm and 
went back. All the servants had come running, and were now screaming to her to come down. "She cannot come! the house is breaking. Fetch her! fetch her! bring a ladder!" I said. They ran to get one and brought it, while the tumult of the crashes and smashes each time the house swayed; the deafening screams of thousands of crows and birds; the frenzied yappings of the three dogs, who stood looking at the house as if they understood; the wild weird sounds of the conches blown by the priests at the temple, on the other side of the garden wall; the mad ringings of their bells, showing their desire to appease Kali, the goddess of destruction; added to our calls to Unda-made a pandemonium of noises that could only be remembered and analysed afterwards. Just as the ladder was brought, Unda herself came, white as death, and we threw ourselves into each other's arms, thankful, so thankful, that we were not hurt. She said that as she was playing her fiddle, all at once she felt the room sway from side to side, and heard crashes. She attempted to come downstairs, but a great piece of plaster cornice fell from above the doorway in front of 
her, and drove her back; then she rushed to a door leading into a dressing-room, but more was falling there; great lumps of plaster, mortar, and dust. At last she ran into her own room, from the verandah, and down the side stairs into the garden, which was east, and did not get so much damage as the west. The poor child, without knowing it, had clung to her fiddle and bow, and appeared with them tightly clasped in her hands, after getting, in a dazed way, down those tottering stairs; and I embraced them all together without even seeing they were there. Ah! Unda, Unda! the little God of Love did later what in those days not even an earthquake could do-make you abandon your fiddle !

Four to five minutes were occupied in these alarming occurrences; then Poonia stood near, with something ragged in his hands, and no expression whatever on his countenance. In his high, thin child's voice he asked :

"Where shall I plant these Calladiums!"

"Calladiums!!" They were the last things on earth I cared about, just then; but he had been sent for them before the earthquake, so his 
small mind thought he was bound to finish his errand.

There being no recurrence of the tremblings and shakings, we stood there looking at the house, wondering whatever had happened inside. Oh! the drawing-room! It sounded as if everything had been swept from side to side. I dreaded to see the desolation there must be, and feared another quake might come if we went inside. Yet what was to be done? we could not stay outdoors all night. Somebody must do something-but what? We sank into the chairs brought out of the lower verandah for us, and waited for another possible shake. In that one just passed, my predominant feeling was, "Oh! will it never end?" I hated it, and felt worried by it. It seemed to go on and on, in increasing violence, and each second I expected to see the earth gape open, and the house fall into it.

"Now," we said, "there may be still a worse one to come."

"Shall we ever be able to live in the house again?"

"How can we tell if the walls will not come 
tottering down when it rains? If we don't go back into the house, where can we go? Every other house must be in the same condition."

"There are the servants' go-downs. We shall have to sleep in the coach-house."

Being of one storey only, these buildings seemed to have escaped damage. Fortunately, nothing fell on the horses, though they were frightened.

"Well," I said, "at any rate we can't sleep upstairs, for that must be where the greatest shaking occurred. To see the house waving like a flag, quite 3 feet from the perpendicular, must mean that the whole of the walls have become loose, in such an old house as this. Perhaps we can stay safely downstairs. I will go and get blankets and pillows, and wraps, in case we have to run out into the garden in the night."

Just then the master drove in, and was greatly astonished to see the portico partly down, preventing him from driving up to the door. He knew actually nothing of the earthquake; having started for home just five minutes before it occurred. $\mathrm{He}$ drove leisurely along by the river-side, wrapped in his thoughts, and noticed nothing of the earth 
rising, or the trees on the roadside waving and bowing. In some places they bowed to each other in the strangest way, as the ground rose and fell, with the passing of the great air-bubble beneath, but he saw it not, and we had to describe it all to him. Then he and I went upstairs together; some of the servants timidly followed us, thinking if we dared to go, then they could also. On the stairs we found masses of plaster and dust only. In the drawing-room, strange to say, the furniture and china were still in their original positions, but great lumps of cornice had come down; and from over every door, 6 feet or more of thick plaster had detached itself from the bricks, and had fallen over everything. A great Satsuma vase, 5 feet high, was broken, but that seemed to be all. The ceiling looked dreadfully cracked, and we dreaded the rain. In the west bedrooms, the same kind of thing had happened; but in addition, a great round tower, leading, with a circular staircase, from the ground to the roof, was wrenched right off the main building, and there was a gaping rent open to the sky. The tower looked as if one push would send it down headlong; so we shut and barred the door 
leading to this place, and warned the servants not to go near. Then we had up all the men we could get, bearers, sweepers, grooms, even the cook; all with brooms and baskets clearing away the fallen plaster from the drawing-room carpets. Tremors were continually going on all that night and even during the next day, and whenever I went upstairs, I felt as dizzy as when on a pitching steamer at sea, and I found it absolutely necessary to hold on to the banisters. This was very much like a wreck on dry land; the sudden feeling of having nowhere to stand, sit, or lie with security. We took needful things downstairs that night, and slept on chairs. The next morning, Sunday, coolies and people were fetched in, and we hurried all the furniture, pictures, and piano out of the drawing-room as fast as we could, and stacked and piled them in the billiardroom; which we hoped was water-tight, being newly built. We worked like slaves, racing the downpour which we knew must come. Before we had finished, it came, a terrific onslaught.

"Come away down," said the master, "it isn't safe; the roof will be in"; but there were still some carved Algerian brackets on the wall that could not 
be detached, and here was the water rushing down all over them. I stood under an umbrella with rain pouring on me from the ceiling, trying to get them off; the man who was pulling out the nails was beaten on and swamped by the floods, and they poured all down the stairs. What a scene! We had finished just in time, and on looking into the billiard-room, I was thankful to see it was apparently rain-proof. We heard of some curious incidents in the town. A man returning from office happened to have had no knowledge of the earthquake. The weather was as usual; everything was calm; not a breath of wind. Yet here was the side of his second-storey room out in the street; with all the clothes that he had intended to change into for tennis, that had been carefully arranged on chairs by his servant. Also his dressing-table. All had come to meet him. His face was a study when he drove up. "Why the - ?" "How the - ?" An enormously stout woman was seen coming hand over hand down the lightning rod from her fourth-storey window. How she reached the ground in safety was a marvel, but she did.

And now began four months' picnic, or dis- 
comfort, according to one's temperament, for it took that length of time to mend us up; and every other house in the place being as much or even more injured than our own, on the builder declaring it safe enough, here we had to live. First they built over us, and then they built under us, and I don't know which was worse. To sit below, necessarily with a window or door open somewhere, and see clouds of dust and bricks descending from the verandah above; to hear the thud of falling walls overhead, and listen to the fierce yells all the livelong day of the coolie women, who were only conversing with one another while carrying hods of bricks up ladders; and to have the odour in everything of their abominable tobacco, which they smoked in place of eating; or to live above, crowded with all the furniture, while they removed portions of loose wall beneath you; till the place gaped like a ruin, and you were warned not to tread over certain parts, for fear of it letting you through ! There was a Mahomet's-coffin-like feeling about it, though we knew they had shored us up with thick tree trunks below. But when they began to attack the tower in order to raze it to the ground, and 
started off with a man astride on the topmost pinnacle, with a crowbar to dig holes in it, and another on the ledge of the roof adjoining, to demolish the side, I began to get nervous, and I took my umbrella and fled me into the garden. However the whole thing did not crumble down that day, nor for many. It was the toughest masonry possible, built by Prince Furrukh Shah's ancestors, of the house of the Rajah of Mysore in the century before the last! Some of the walls are 4 feet thick, and this enabled the old house to survive the unpleasant twists it received. Now, as old concrete roofing is about the most agreeable sustenance to ferns in general, I resolved to appropriate a good deal of it and have it conveyed to the south end of the garden, where the high wall at the back and the trees overhead would give all the shade required for ferns. It would partly hide the old wall, and would give something more interesting to look at. As for growing! The ferns would simply leap! The whole city being under repair all at once, and every possible coolie engaged by the builders, I started operations with the individual whose business it was, for twelve shillings a month, to waggle 
that holland frill overhead, in the vain endeavour to cool us; and him I caused to carry a basketful of lumps of the broken roof and dump them down in a line by the wall. The larger lumps he carried one at a time on his head, so our progress with the rockery was somewhat slow. Anyhow the preparations for it were more interesting than sitting indoors covered with dust and native tobacco smoke; for all the world like living in a "bustee!" The poor women always take their babies with them when engaged in building houses, and naturally the infants cry, which is very plaintive when you can't stop it. One was terribly frightened once when I spoke to it. Its little elder sister smiled pleasantly, but the babe clung to her in mortal terror. "What is it? What is it?" it demanded, and roared, much as an English child might, on seeing a black man for the first time. "What is that dreadful thing?"

Unda had an unfailing resource in her fiddle, in playing which she did not notice the other noises! We might, of course, have gone away and sat on a mountain top, though it would have been a two days' journey to have found a safe one, and left the Burra Sahib and the Ancient to worry along as 


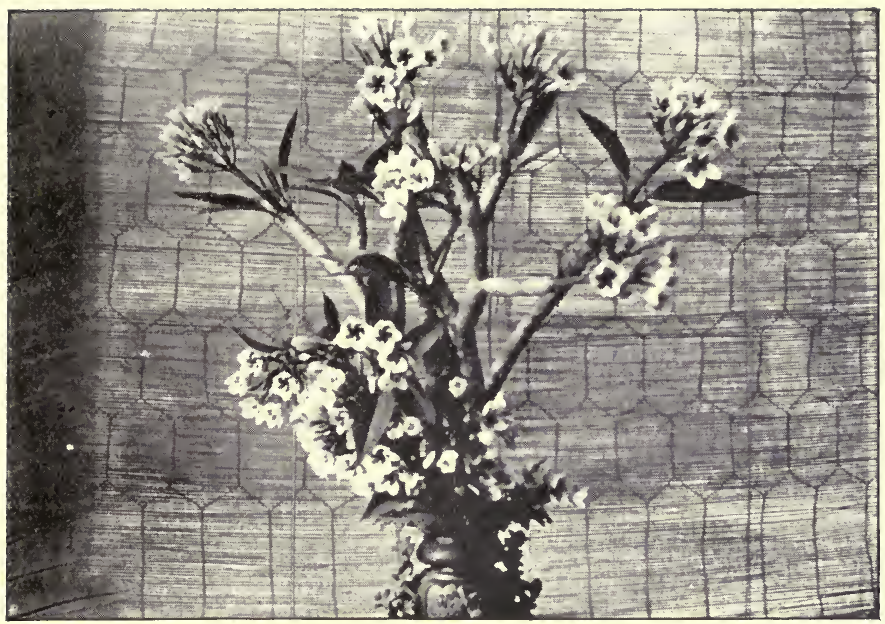

A Sprig of the Frangipanni Tree.

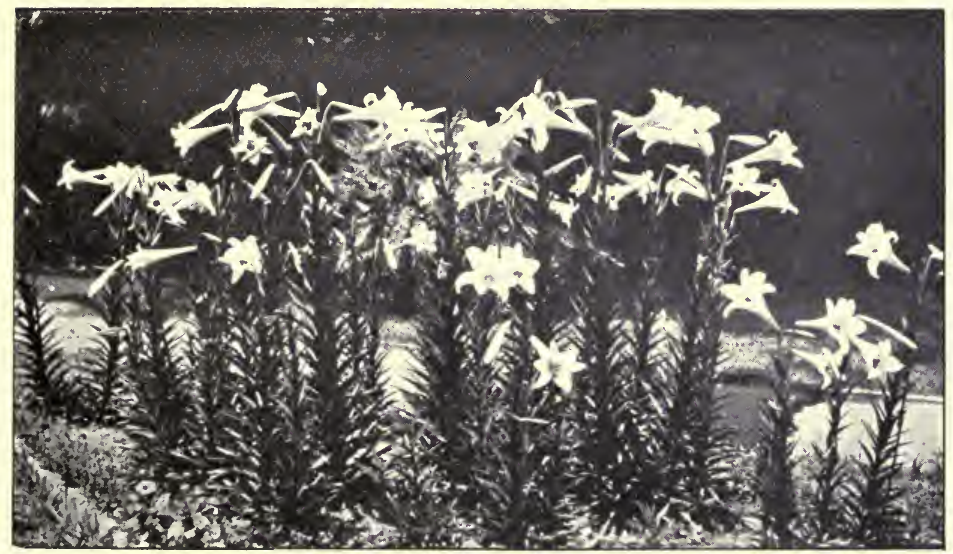

BERMUdA LILIES 

they could. They would probably have found mortar grits in their soup, and fungus in their boots, and everything we possessed would have become mouldy in the humid air; and devoured by white ants, through not being turned out in the sun whenever the rain held off. Also, they would have been extremely worried by the builders never being within reach when wanted to give orders to, nor the painter to choose colours for the walls; these individuals only working between ten and five; just the time when the masters were away. Fortunately the Burra Sahib's and the Ancient's rooms were untouched during these upheavals, and they were enabled to go and come as usual; but it required much manœuvring and Mark Tapleyism to keep things going fairly comfortably for all in such adverse circumstances. Then servants are not much use in unusual times like this; they have no eyes. Our senses had always to be on the alert, never to leave anything about likely to be stolen. Even as it was, the most undreamt-of things were taken. The brass ends of poles were unscrewed; wall lamp-brackets, whole lamps even, we found gone when we came to refurnish. Even the hooks 
in the punkah poles had been taken out. Natives are very fond of brass. It was quite impossible to keep an eye on everything, so jammed up as it all was.

However, we were all straight again before Christmas, and the rockery was done and planted out, a border about 320 feet long, and christened the "Punkah-wallah's Walk." These plants are now some of them a tremendous size, and each will divide into dozens of pots, and still leave some for the rockery. All the numerous Ferns, and Dieffenbachias, and Calladiums, are from very small beginnings. Just a pot or two of each kind, divided at the proper time into good earth, and now there are quantities. This is very economical gardening, and so much more interesting than getting plants ready grown by some one else.

About a month after the earthquake, we had another experience, riots. These were begun by a dispute about a piece of land that was sold by a Mahomedan to a Hindoo. The Hindoo bought it with the intention of building himself a house on it. To do this, he began to demolish a little old mosque that was in the way. The Mahom- 
edans objected to this, as a mosque once must be a mosque always, till it tumbles down of its own accord; so to law they went, and the Hindoo got his decree. Now you may imagine the ferment. Thousands of Mahomedans rallied round the old mosque to prevent its demolition; and thousands of Hindoos supported the new owner, who wanted a house on his land, not a ruin. In addition to this, the Mahomedan's Mohurrum clashed that year with some Hindoo feast, and processions of these parties fought with each other. The Hindoos were bitterly incensed because the Mahomedans, after their forty days' fast, killed a bullock for their feast just close to a Hindoo temple. In revenge, the latter bribed some of the lowest caste sweepers to throw a pig over the wall into a Mahomedan mosque; so the most fervent flames of religious hatred arose, and they were ripe for giving trouble to each other, or to us ; no matter whom. The Police not being strong enough, the Mounted Volunteers were called out, and paraded the streets all one night. One evening about eight o'clock, a rumour reached me that 400 mill employés had struck work, and were marching in 
from the outskirts, when they would inevitably pass this house. They were said to be armed with sticks 6 or 8 feet long, and were destroying and looting as they came. We hardly believed it; but supposing they reached as far as this before they were stopped, it would not be impossible for them to enter this house, and, at any rate, try to do some damage. There was no shutter to the front glassdoor; and all the bricks and rubbish lying about in heaps would make fine missiles. The entrance gate of wood had been on its last legs for years. Every year I had been promised a new one, but it never arrived. It was tied here and there by bits of string, and fastened with tin tacks, to make it hold together sufficiently for the door-keeper to open and shut it once a day.

"Now," I said to the Burra Sahib, sorrowfully, "if only we had got that new gate, we should be safe. As for this, the smallest push will stave it in."

"Oh, that's all right," said he, "they will never be allowed to get as far as this. The regiment from the lines will put a stop to them before they get half-way here." 
"One can't tell for certain," I said, doubtfully ; "they are co-religionists."

The little Ancient looked as if he were quite enjoying himself.

"Why be frightened?" he asked, beaming over his spectacles. "Are not we here?"

I remarked that I was not frightened, but I was determined that they should not come in. I beckoned Unda out quietly.

"I am going to barricade the gate," I said, "with servants!"

We went towards it, and I explained to the door-keeper what my views were; that there were a bad lot of people said to be coming along, and that I did not wish them to be allowed to enter to destroy anything. Soon I was surrounded by all the servants, who entered into the spirit of the thing at once, and loudly declared they would stay by the gate, and wouldn't let any one in. They ran to find long sticks for weapons of defence.

"Unda!" I said, "let us give them the assegais from the hall!"

No sooner said than done. They were rusty, 
but that did not matter. There were plenty of them, enough to go all round, and each took one. All the Hindoo house-servants, and the Mahomedan table-servants, the grooms from the stables, the gardeners, the sweepers; a motley crew! To see the gentle old Hindoo, who had been the Burra Sahib's personal retainer for twenty years, solemnly looking at his frightful sticking instrument with his one eye, was very funny. He could see very little even with that, so, some time ago, his master had presented him with a pair of spectacles; which I said was extravagance. Having only one optic, an eye-glass would have been more suitable. An eye-glass under a turban! It would have been uncommon, to say the least. These glasses were very large, and perfectly round, and made him look like an owl. I don't fancy he would have done much damage to the looters. However, I preserved a serious face, and one and all declared they would sit up all night, if I would give them a little tea and sugar! My noble warriors! Certainly they should have something to keep up their spirits with during the siege. So little parcels of tea and sugar were doled out to each man. When we went to 


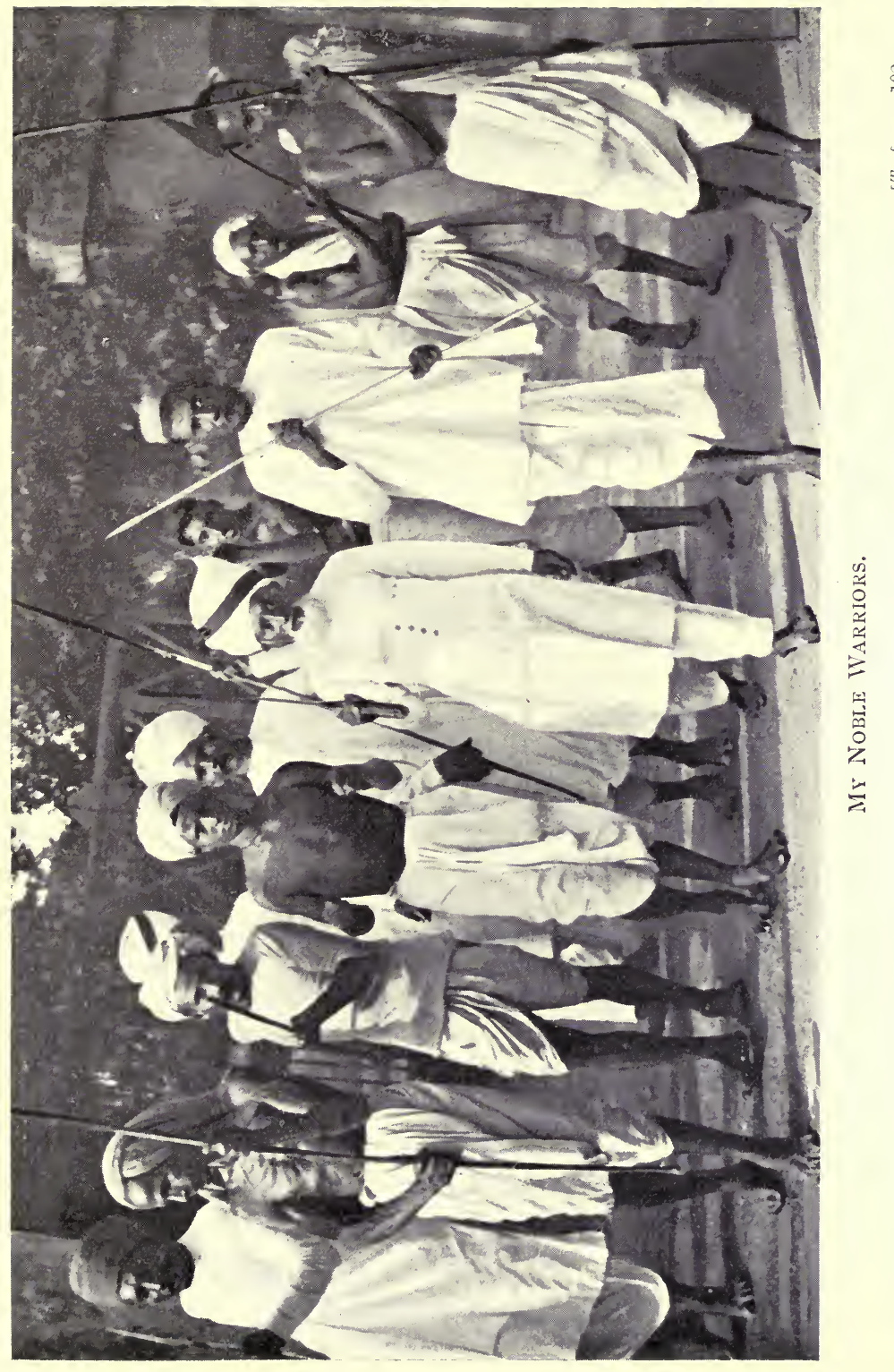



give it, we found that they had brought their charpoys, and ranged them all along the gate; so that was how they were going to defend us! However we left them with many injunctions to watch for the first man's head climbing over the gate, and to give it a good prod with the assegai! We never believed they would, though. Then we went and found the Burra Sahib and the Ancient both fast asleep, in their chairs. We woke them up, and triumphantly acquainted them with the measures we had taken for their safety; after which they humbly went to bed.

So did not Unda and I. We decided to lie down on a couch in our clothes, in case of a surprise in the night. I am bound to say we did not sleep much. In the still air once we heard shouting, as of a multitude at a distance; it made us spring up with staring eyes, and clutch at the old naval sword that we had placed all ready on the table, having well sharpened it on the master's razor strop. Two or three times we heard it, and once several shots were fired close by, in the middle of the night. It was most exciting, but nothing else happened, and we never heard the reason of those shots. After- 
wards we were told that the rioters had started, but were headed off and dispersed a long distance from us. In reality there had been another party coming from the opposite direction, of which we knew nothing, and it had been feared that they would join hands with the first contingent: their two roads meeting at a point, of which our house was the corner. It must have been their shouts that we heard, for they actually did pass, only they cunningly broke up into groups of four or five just before they reached here, for fear of being stopped at the lines if they appeared as a mob. The Burra Sahib went to buy me a revolver the next day, but every shop had been cleared out, and there wasn't one in the whole place; so the only thing to do was to write home to the Professor to send one out; which he did in six weeks' time, with a recommendation to erect a Gatling gun on the roof. By this time all was quiet, and the revolver has never been let off, except to shoot at bottles in the pond. Many ladies, though, carried one about with them whenever they went out to dinner, and would pull it out of their pockets and exhibit it to you at odd moments. One unexpectedly produced hers at the 
bandstand, to the great distress of her husband, a gallant Major.

"Oh! if you don't put that thing away, I shall get out of the carriage," he exclaimed. "You are pointing it straight at me. Sit upon it! Sit upon it!"

A very serious side of the matter might have occurred, had the rioters succeeded in their fiendish endeavour to injure the pumping-station, whence we derive our supply of filtered water. Hundreds of them besieged the station all night, in order to get in and wreck the engines. Think of that, in such a climate, and in such heat! It would not have affected themselves, as they prefer the muddy river and stagnant pond-water to drink, after having washed themselves in it; but to us who are not inured to it, it would have meant an immediate outbreak of cholera. Fortunately the station had brave defenders, who at last beat off the attacking party, and the disaster was averted.

The plague regulations displeased all the natives very much. Two rules they would not give in to:- segregation, and the entering into the Zenana by the Inspector in search of plague patients who 
were known to be hidden. Thousands of natives left the city every day, domestic servants among them. Several people had hardly a servant left, and one husband we knew had to pull his sick wife's punkah all one night. We came off very well, as none of ours fled. I asked one of them why they didn't. He said, "Why should we go! everywhere is the same, and we know you would do all you could for us, and we think we are safest here." We never had a single case inside the gates, but my poor laundry man succumbed, as he lived outside. I constantly had the interiors of their rooms washed with phenyl, and even the wall syringed with it; and gave them soap for their own ablutions, with strict injunctions to the head man to act as Knight of the Bath to all the rest. So, had the plague come to us after all, it would not have been for want of cleanliness. A most curious thing occurred some years ago, whether in connection with plague or what, no one knows to this day. One morning all the mango trees for a hundred miles were found blazed and daubed with mud. Who could have done it, and why? What did it portend? Though 
many inquiries were made in the newspapers, no native has ever come forward to explain it, though they must know. That was the merry month of June, as this is. Since that year of earthquake and riots we have had famine after famine; and its sequelæ, plague; also floods; and this year we have been threatened with locusts. Thousands of these insects are settling in parts of Poona, and upcountry districts; and even here some have been already picked up by natives, who take them home and cook and eat them, either boiled or in curry.

I was having tea outside the Ipomoea-covered arbour, when in the space of a second a rain-cloud burst. To move chair and table in underneath was the work of another second, and there it was possible to remain dry, for a time at least, until the leaves became saturated through. Such beautiful warm rain as it was! No wonder the Livistonia's face shone as it turned it up towards the shimmering drops. I should like to have done the same thing myself, were it not for the trouble of changing garments after. As it was, I was perfectly content to sit under my white cotton sunshade (the master having taken my second umbrella), and 
enjoy the sight and sound of the refreshing onslaught all around, while sipping my tea; but in a few minutes the drops began to come through the leafy roof. Outside was already a sheet of water ; it was impossible to get to the house quickly enough to avoid a wetting, the paths having at once developed a brown fungus as slippery as glass, compelling one to walk delicately, like Agag. I really must inform the Burra Sahib to-night that,

"The rain it raineth every day

Upon the just and unjust fellah,

But chiefly on the just, because

The unjust's taken the just's umbrella."

Suddenly the rain stopped, and the sun shone, like a child ceasing to cry, and shouting with laughter. My chair and tea-table were surrounded by a pond. The Grey Beard came to see after me and remove the tea things, and him I desired to bring the master's boots. In them I was able to wade about dryshod, and see how fresh and sweet everything looked. The Maréchal Niels, the Sunflowers, the Cannas, all with different shades of green in their leaves. Strange, in how short a space of time, only a few days since the rains 


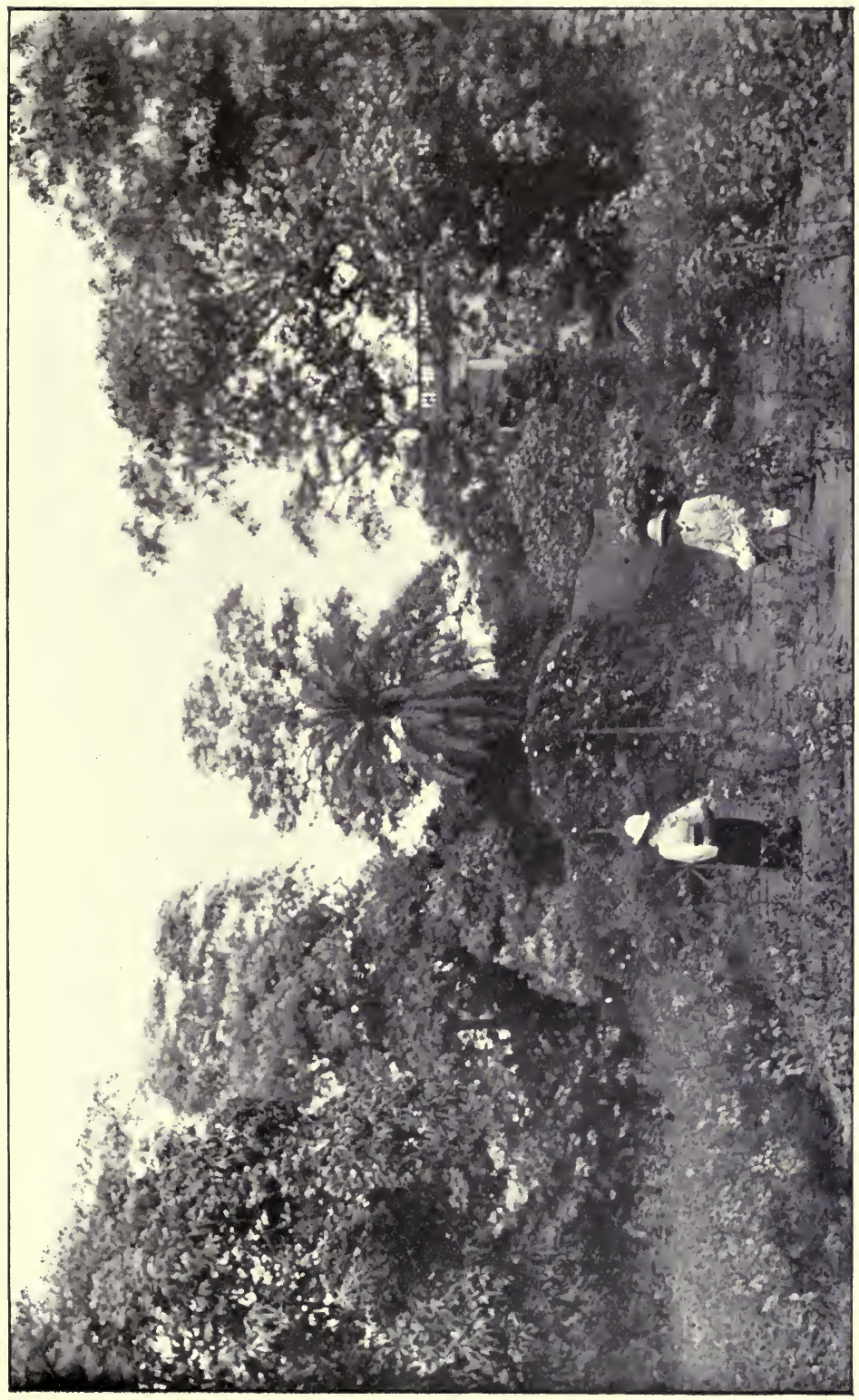

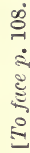

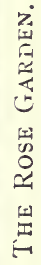



began, every plant and tree has thrown out new and vivid colouring. The Debdar's last new leaves hang like delicate green-yellow gloves, against a darker background. The Teak tree has blossomed into great masses of tiny white flowers, and resembles the elder flower at home, except that the teak is a much larger and taller tree. The Fiji Nettle has reddened all its leaves to a most brilliant crimson. That hedge of them has grown too high though, and must be cut down to 5 feet. Now the young fronds of the palm Litania on the lawn are shooting up with ruddy rhubarblike stalks. It is to be hoped the boring beetle, with a pointed stick for a head, will not come by, and pay his unwelcome attentions to this palm, as he has done to the two at the end of the lawn. He always bores straight into the very youngest and juiciest frond, whereby it rots, and so destroys the plant. The Burra Sahib sets great store by this palm, and so far it hasn't been attacked. As for the Crotons-those magnificent plants, desired by all who had gardens thirty years ago!-they have now become so common that no one cares about them, though they are just as 
beautiful as when people raved over them, and gave 50 rupees a plant for them at auctions. Croton Broomfeldii is extremely handsome, with very large oblong leaves of a bright yellow, veined with green, thick and leathery. Croton Longifolium is a lovely shrub with narrow yellow leaves, 18 inches long. Croton Jacksonii is very handsome, with its long bunches of twisted and curling fingers of leaves, dark red in colour. Another has narrow green and yellow leaves 2 feet long and crinkled, a lovely drooping variety, the Gloriosus. There are crowds more, all banished to far away corners ; but with the growing blush of new colour, shining with the rain, they are quite dazzling to the eye, and stand mutely protesting against fickle fashion, which cannot value anything that is shared by everybody, and only cares for the last novelty. Now is the time for taking cuttings of them. If I were to grow some in pots with plenty of leaf mould and bone meal, they would be very showy for the "Lean-to," at a time of year when coloured leaves are so valuable. Just now the handsome red single Hibiscus is out, and the curious tasseled one also. They evidently like their new position 
against the east wall, so I will clear out a border there, and have a row of salmon, rose, white, yellow, scarlet, and the blushing one that comes out pure white in the morning, and faintly blushes by breakfast time. At lunch it is pink, and by night a dull red, and dead. There are many visitors to see my Garden-Beautiful now. The green of the leaves, the varied tree foliage, from the palest green to the darkest; the yellow of the Crotons, the bright red of the Acalypha or Fiji Nettle, the pure white of the Pampas Grass, and the abundant yellow of the Allamanda; with the scarlet Ixora, and the bright purple Bougainvillia, that completely covers an old mango tree; with also the showy reds and yellows of Cannas, and the magnificent tresses of orange-coloured Tecoma Grandiflora, make a glorious Eastern coup-d'œil. 


\section{JULY}

"How my spirit sighed

To be an artless Bandar

Upon the mountain side!"

Rudyard Kipling.

THE rains have deceived us! During the first part of this month we have only had showers, with intervals of torrid steamy heat for days together, rendering it almost impossible to do the longed-for transplanting. The path-making has progressed considerably though, under C. S.'s auspices. Where an uncomfortable looking right-angular corner had become overgrown with trees, the path has been curved round the awkward places, and now forms a series of graceful outlines. "Hallo!" said the Ancient, "railways about," looking at the 5-feet gauge of brick edging. We have immensely improved the appearance of the garden. Also another piece of work is completed, 
and that is the brick gutter conveying the rainwater that drains off the lawns after a storm. In July and August this water used to rush into the pond just under the peepul tree, with such force, that great landslips were caused in the bank, and the path by the pond became undermined and dangerous. Now a graduated series of steps breaks the force of the waterfall, and the C. S. has diverted the path, by winding it round on the other side of the peepul tree, which looks very much more interesting. Under the tree I have made what Jogee calls a "hill," being the highest bit of land in the surrounding country. I should say it is quite 6 feet above the level of the sea, and here dwell Coleus, the very newest out, with rich coloured leaves of mottled reds and greens and rose-colour; also the pretty blue plumbago and a little coffee-bush with real live coffee-berries. Odd bits of ferns and Amaryllis add to the general effect in my opinion. Do what he will, I fear the master will never teach me to be anything but a hotchpotch gardener.

It is most satisfactory to see how well the waterfall acts, after a storm such as we had to-day, 
of 2 inches in one hour. The torrent rushes along the gutter like a tiny mighty river, and leaps from step to step, dropping with a roar like a miniature Niagara, into the pond that is now beginning to rise every day. The pond is $\mathbf{1 2 0}$ feet square, and 20 feet deep, and when full is a good expanse of water; in the hot weather it nearly dries up, though. We wish so much that it would keep full up to the edge, or even half way, as then we could make it look more ornamental with aquatic plants and water-lilies, the sacred lotus. When full, it shows picturesquely the variegated shrubs planted round the edge, reflecting back their vivid colours.

Now I have had some trouble in persuading these plants to grow. I was most anxious to lessen the ugly square appearance of these bare banks, and I planted one thing after another, but with no success. Everything would die or shrivel up, chiefly owing to the bad soil and the strong growth of grass roots, and by the fierce heat of the sun reflected from the water as well as overhead. But at last it is looking quite decorated, after repeated efforts. Over the arbour from which 
descend the sixteen steps is a thick mass of Allamanda Grandiflora and Bignonia; the yellow Allamanda blooming all through the rains with its large open flowers 4 inches in diameter, and the purple Bignonia in the cold weather. At the northwest corner stands a Bauhinia that has rapidly grown to 26 feet in height. It forms an arch across the path with some tall sago palms and white ribbon grass 6 feet high, a most effective grouping to look at from the gate, or the verandah. Continuing along the pond pathway, there are bunches of Canna; an Allamanda, shrub size, but full of flower; a white grass, a Quassia; and the eye now catches the gleam of the water through the leafy shrubs, instead of being stared out of countenance by it as before. On the opposite bank are dotted great clumps of another kind of pale greenwhite grass, with a Maréchal Niel in the centre, which have now grown well, though in the glare of the western sun. The south-east corner is broken by an arbour covered with Poivrea Coccinea, which blooms spendidly with long scarlet racemes in the cold weather; along the south bank are again Cannas, red and yellow, more Allamandas, and 
scarlet Ixora and white grass ; forming an excellent foreground for tall pink Oleander and the purple Bougainvillia, that showers its masses of colour all over the old recumbent mango tree. Everything with colour has a place in my estimation.

Last rains the pond overflowed, and converted the whole garden into a lake; the ducks and fish all swam about on the tennis lawns. That was after six days' hard rain, night and day, during which 37 inches fell. Fifteen fell on one day only. Oh! how tired we became of the incessant rattle and leaking roofs. In every room upstairs were streams of water, and damp and fungus below. A fever patient, and the kitchen flooded !-I, who was the invalid, could hear my broths and beef-tea plunging through the flood and torrential rain, at all hours of the day. How sorry I was for the poor people who had to be constantly wading half up to their knees in water (fortunately it was warm !) to bring in whatever was needed from the kitchen. I feared an outbreak of fever or cholera among them, but oddly enough, they were none the worse till the ground began to dry, and give off exudations of miasma. Even then only one or 


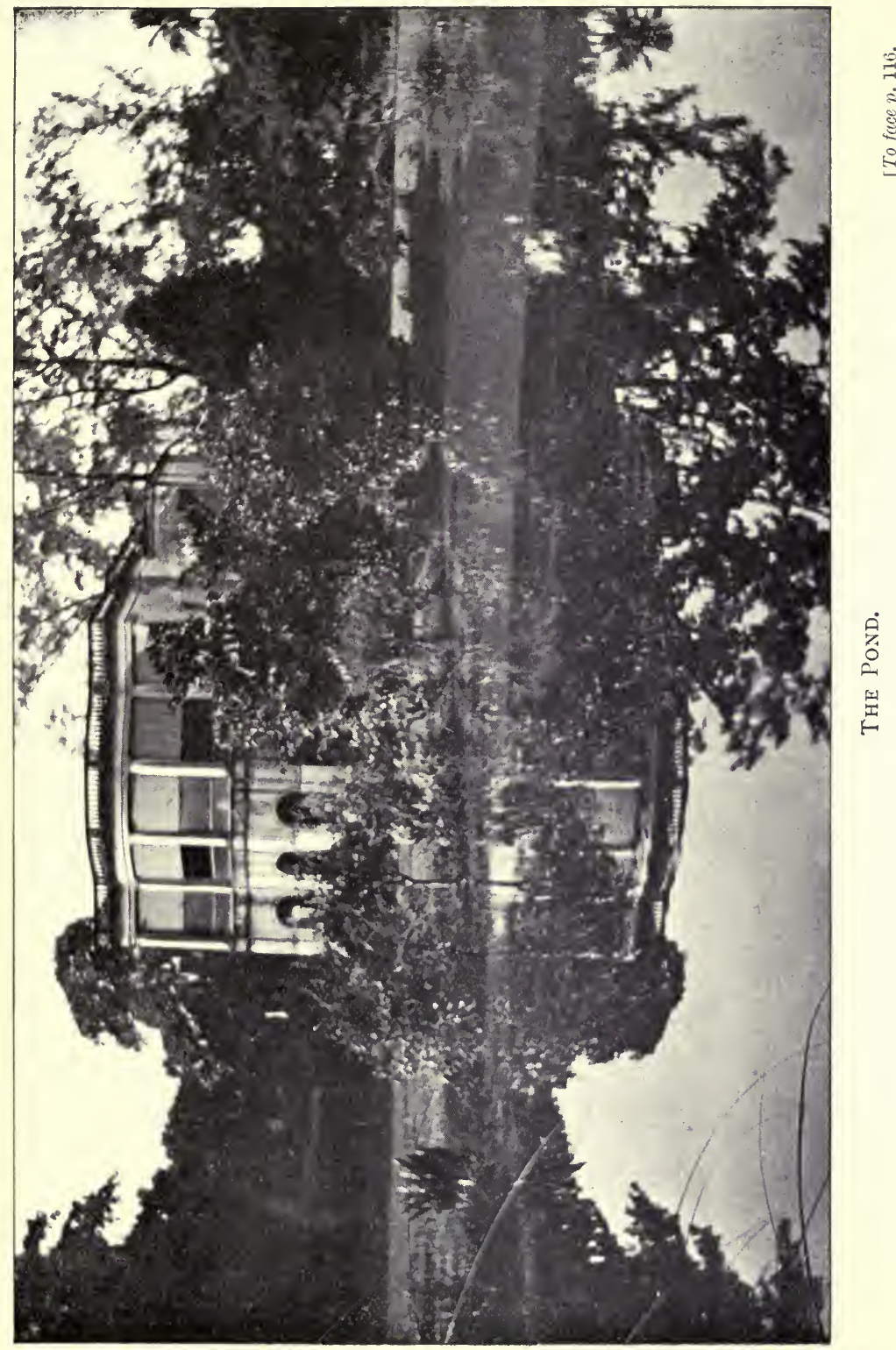



two had fever, but I carefully dosed them all round every day with quinine, well and ill. The whole town was under water, 2 or 3 feet deep in places, and all the fish came out of the great tanks and swam along the streets; brisk fishing with nets was to be seen going on in some of the roads; in others, Europeans rowed themselves about in boats and punts, and some even in bath-tubs! Native huts built of mud would suddenly melt and sink into the water, and the thatched roof would descend on sleeping children, killing some. Out of the thatch crept venomous snakes, and scorpions, biting and stinging unwary people in the dark. Snakes were flooded out of their holes, and some were to be seen crawling in the evening on the dry bit of road just outside our gate. I gave several extra lanterns to the servants, with injunctions never to go about without a light. This year we have certainly seen very few, and it is possible that as they were swamped out of their holes, so they departed. It was fortunate we had a farmyard to rely on for our dinners, for on two occasions no beef or mutton could be procured in the market, nor could vegetables or fruit be brought 
in from the country. So too much rain is quite as inconvenient as not enough. We all hope and pray that just sufficient may fall this year to induce a plentiful harvest, that a famine may be averted, for once, from the ox-like, patient, suffering, rural population. Towns do not feel the pinch of famine as the country does. The inhabitants of this city are mostly earning good wages, and there is food enough for all here; though it becomes dearer, it simply means that a plainer diet must be indulged in for a time. Rice and dall, instead of curry and sweetmeats. The only article for ourselves that becomes really higher in price, is the food for the horses, oats and gram; though the famine, when there is one, is generally made the excuse for an attempt to raise the price of every single thing we eat, whether imported from Europe or not.

On the 1st, after breakfast, I found Penelope in perihelion again. I had forgotten all about him during his dark side. I took one piece of work, and gave him another exactly similar, and I raced him. Mine was done much sooner, and quite as well.

"Penelope," I said, "why can not you do that 
as quickly as I can? I have even been interrupted several times ; letters to write, and so on."

"God knows," said Penelope. "He has made your highness a lady who can do everything, and me he has made a poor, ignorant man."

Penelope the next day was given dusters to hem. In the evening he said :

"Here are fourteen still to do. I will take them home and finish them there; then $I$ can also attend to the rebuilding of my cow-shed, which has fallen down in these heavy rains." In this way he gets a day off, and so do I. He is a man of wealth, and possesses a milch cow, and his wages are double those of some of the servants; and yet he is always trying to get money in advance. He assures me on the 1st of the month that his interior, expressed with biblical plainness, is very empty, and that as I am a "Protector of the Poor," so I will at once give him something on account. "Penelope," I say, "you know it is the custom of this house to pay on the 5th, so why do you ask? All the servants will get paid together."

Another time he will weep, and say his daughterin-law has just died, and he wants to bury her; so 
I hurriedly give him an instalment of his wages this time. One cannot always be thinking of the possibility of untruthfulness, though Penelope seems to have double the misfortunes of the other servants.

"What a beautiful bird the peacock is!" Unda used to exclaim when she wished to change the conversation. With that object I say, "What a beautiful bird the kingfisher is!" I saw one flying across the pond, just skimming along close to the water; a lovely bright blue. They are shyer than some of the denizens of this garden. The golden oriole will let you come rather near, and I can often catch a glimpse of his bright yellow plumage, as he darts into the sun for a minute, from one tree to another. The king crow is a handsome black bird, with a crest on his head, and a long swallowtail. He is rather stand-offish, and I can never get near enough to see him well, being short-sighted. Owls innumerable there are. It is said to be unlucky to shoot one. Unda did, but no bad luck has yet arrived, and that is some three years ago. There are also crowds of brilliant green parrots flying about with harsh squawks, adding to the 
clamour. Parrots love the seeds of the sunflower, and may be seen in dozens hanging under the great heads of the flowers, extracting the seed when it is ripe. Some of these birds have curious notes. Very often there is one calling, "Jogee, Jogee, Jogee," and he is answered by another, who sounds like "Cocky, Cocky, Cocky." This bird will always oblige you with an answer, and go on for an hour if you imitate him. We were once visited by a whole party of vultures; birds that we have never before seen in the garden, or anywhere near a house. We could not imagine the reason, when we saw them flying about over the distant part of the garden, so we went out to see; and there we found a dead cat in the path. So that was their object; but how piercing must be their sight to be able to distinguish anything so small from the immense height at which they fly. The Burra Sahib counted thirteen of them round about in the various trees; two being king vultures with red on their heads. They quietly sat there, waiting for us to go; a most unusual sight. The master had his gun brought, and he shot one. As it lay on the ground, I thought I had never seen a more wicked- 
looking pair of squinting eyes, and horrid hooked beak. From point to point of its wings, it measured exactly 7 feet. A truly terrible object. A great contrast to this ferocious bird of prey, is the homely little brown-and-white mina, nearly the size of a pigeon, which inhabits these trees by the hundred. One pair always brings up a family in a recess of the coping outside the upper verandah, and there they squawk and scold and wrangle, flying inside to be fed with bits of toast in the morning. Klinker must have offended them in some way, for every time he goes out into the garden, they are down upon him, nearly nipping him on the back; and they chase him half over the garden. This only occurs with Klinker; never with Nous. Sometimes the crows, which are not crows at all, but plain and simple jackdaws, will endeavour to compete with the minas for the bits we throw. So soon as they do, Klinker is in the midst of them, scattering them to right and left, and dispersing them; but he never disturbs the minas. I said to the Ancient :

"Tell me, why did the cro-cus? Not because he found hell-e-bore, but because Klinker stole 
his bone!" The language that crow used was dreadful, standing with his feet wide apart, and swearing at Klinker as he lay at full length crunching the crow's bone. The impudent crows sit on odd corners of windows and doors waiting for meals to be finished, so that they may possibly get a pick at the plates. The last thing I would do would be to feed a crow, so I will not allow Canary to indulge in one of the customs so dear to an Eastern, that of throwing out of doors all scraps of meat, fish, and vegetables, from the plates, leaving the pile of rubbish for hours till the sweeper makes his rounds. This is why we have so very little of the crow nuisance here, which renders the city almost intolerable. There thousands of them awaken the weary sleeper at dawn, with their hoarse discordant screeches, and again in the evening at roosting time; and there they become so bold that they will abstract the toast from baby fingers, or from the table at which one is writing. On arriving in India for the first time a quarter of a century ago, my deepest ineffaceable impressions were crows, flaming sun, and scarlet Hibiscus. In those days there 
were adjutants on every pinnacle of Government House, sitting perfectly still all day like graven images of bald-headed old gentlemen with hands under their coat-tails, waiting for evening; when they would descend with heavy flapping wings, to stalk about the streets, scavenging among the heaps of refuse, piled close to the entrance gate of every European and native household. A most disgusting sight it was, that rubbish heap, and being at the gate, there was no possible way of avoiding it, in going in or out, with results disastrous to the sight and smell. Circular galvanised bins are now placed near every doorway instead; so that nothing is visible, and if one does not walk too near, the senses are not now assaulted. Thus the adjutants, finding nothing to scavenge, have departed.

Tame birds are great company. I have only to call over the banisters, or whistle from the bottom of the garden, to start the whole row of six into song in answer; though song is not exactly what you would call the white cockatoo's way of expressing himself. $\mathrm{He}$ is fond of being stroked and petted, and he begins a loud screech when he thinks he ought to have a little attention. He erects his 
yellow crest, feather by feather, which shows he is getting angry; and he raises his foot and paws the air, with a louder scream. If this has no effect, he ducks his head and then raises it with a jerk, every feather bristling, and with the extra power thus gained he sends out the most appalling yell, like a veritable demon. All this while the green parrot is in a great state of excitement, and keeps continually calling, "Pretty Polly, Pretty Polly, quite well, quite well," as if to appease the angered one. This is what Klinker never can stand. As soon as the cockatoo begins, he goes and plants himself in front of it, howling with all his might, till one is compelled to leave everything, and go and stop the turmoil. Klinker cannot bear double notes on the violin either. It makes him cry as if his heart were breaking. It was the climax of all woe to him, when a violoncello was played one evening. There were the three enthusiasts-'cello, violin, and piano, in the middle of a lovely trio of Haydn'swhen in came Klinker, groaning. We could not speak to him, playing "presto" for our lives, and he sat himself down in front of this new instrument of torture, and lifted up his voice to the highest 
pitch of dolour with long-drawn - out wails and howls. The finale came to an end with a crash of chords, and we all burst into a laugh, with a clapping of hands :-

"Why, Klinker, you have turned the trio into a quartette!"

The little garden bulbul has a friendly kind of chirp, and after a seven years' residence close to a shama, has acquired some of the latter's notes, which to my mind are among the richest and clearest a bird can possess. The bulbul is brown and white, with bright red under his tail. The shama is black and polished, with a brown breast, and has two very long straight white feathers in his black tail. His beak is intensely sharp and pointed, and he is carnivorous, and is fed by his own special man, who comes every day. To shut one's eyes and hear his long-drawn liquid song, in varied cadence, makes one imagine oneself in a forest glade, amid bosky dells and rippling water ! $\mathrm{He}$ is a shy bird, and in Java keeps to the tops of trees a great deal, wherefore the natives here cover their cages with a muslin cloth, and hook them high up to the ceiling; as otherwise, they declare, 
they will not sing. I gradually accustomed mine to do without the cover in the daytime, only putting it on at night for warmth, and lowered the cage as he became tame; till now he is on the same level as the other bird-friends, and will even snap soft biscuits from any one's fingers. At the sound of my voice behind the shutter, he jerks his head, and flicks his long tail straight up and down, and bursts into loud calls and "jug-jugs," combining the voice of a thrush with that of a nightingale and of many other birds. $\mathrm{He}$ is also a mimic, and will imitate the shrill "cheel" of the kite, or the mewing of a cat, or the creaking of a rusty hinge, which is not so agreeable. I have had him for eleven years. Last year I lost another that we had had for sixteen years. The Burra Sahib gave him to me when all the "chicks" were left behind in England, and he was a great friend. He was in beautiful plumage and full song, and did not look at all an old bird. At any rate he did not die of old age, but was frightened to death by a rat, which crawled down the rope of the cage during the night, causing the poor bird to flutter round and round till it dropped dead. So he was found in 
the morning. I discovered that to be the reason of his death, by hearing the other one fluttering some nights after, and on quietly creeping downstairs, there I saw Master Rat inside the cage. He lay low in the tin tray underneath when he saw me. The first thing was to unloose Nous, who knew all about it, and stood staring at the cage with gleaming eyes, while the Burra Sahib opened the little door and patted the other side. Out jumped the rat, right over the master's shoulder, and straight into Nous's open mouth, whose jaws but once said "crunch" and all was still. The rat never reached the floor at all, and it was all done in a second, without any scuffle. After that Nous went back to his charpoy, such a sleepy dog! The next day the cages were moved to a more rat-proof situation, which was rather difficult to find, because if hung between doors, the enemy climbed the curtains, or else scrambled up wall draperies, or sprang from hat-pegs. I was so afraid for my birds, that the least flutter would awaken me, and many a shikar we have had at two in the morning, till now at last a safe place has been secured for them all. 
The rats in revenge come prowling all about my room. I hear them snorting and tearing up paper in the waste-paper basket the moment the light is out, and prodding with their noses against the lid of the soap-dish in the next room. Soap they love, particularly good kinds, and it is most annoying to go to one's bath and find that the rats have taken away the soap.

"What! no soap? So she went into the garden to cut a cabbage-leaf." But she doesn't. It would be untimely. Poor tired Unda could not always remember to put away her gloves after a dance. So sure as they were left on the table, they would be found next morning with half the fingers eaten off ; -

"And there, dear Unda, goes 6s. 8d.! a lawyer's fee!"

As for sofa-cushions, we haven't one that has not had its corners nibbled off, to yield up the seed of the tree cotton with which the pillow is stuffed. Traps have no attraction for them in the house, though baited with the best soap; and poison we cannot use, on account of the dogs. In the kitchen, though, once the cook's boy sat up all night, catch- 
ing them. Directly he heard the gin snap, he extricated the creatures, putting them one by one into a cage, and reset the trap; till in the morning he brought me fifteen dead animals; such a ghastly sight. There are field rats, bandicoots, and musk rats, but I believe none of the species called plague rat; for which I am thankful. The others are fewer in number than they were, owing to constant supervision in corners by the kitchen, compulsory sweeping away of rubbish, and the observance of strict cleanliness, combined with phenyl. These servants like to live like rats themselves, and it is a battle of one against twenty-five. I think perhaps the absence of snakes this year may be partly owing to the garden, also, being kept well swept, and the jungle cut, and rubbish corners of bricks turned out. Also the constant digging about that it gets, with the numerous alterations, is all distracting to them.

A most magnificent palm, a special pride of the Burra Sahib, the Arenga Saccharifera, growing close to the house, has now reached the height of 35 feet or so, from 20 inches five years ago. Its lower frond touched my window, and last rains a 


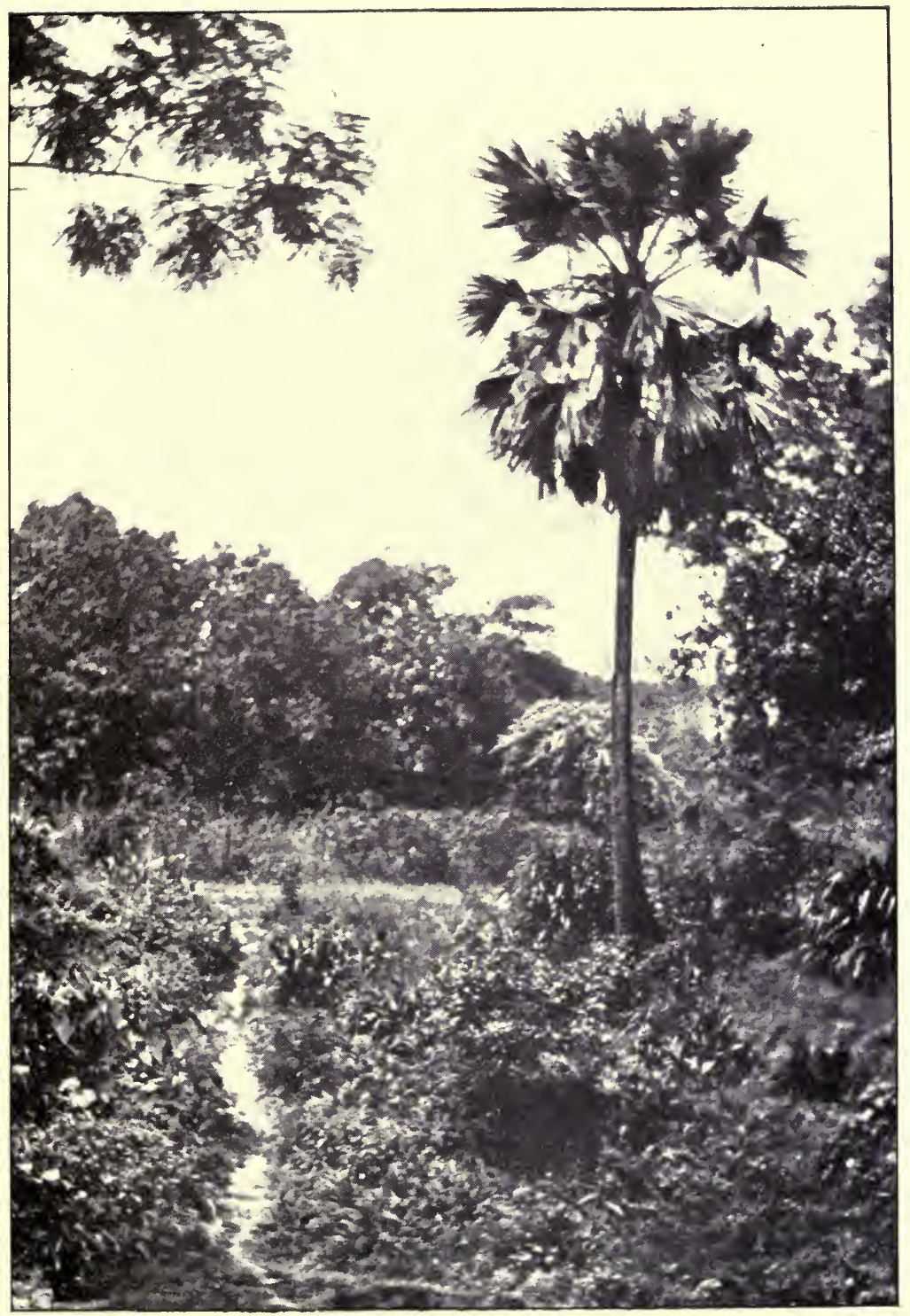

PALMYRA PALM. 

pretty harmless little grass snake crawled up, and into my room, where it was killed before any of us went up in the dark. But suppose it had been a cobra! I have had a weird feeling of suspense at night sometimes lately, on hearing unaccountable noises; so the other day, when I was wearing the master's shoes I ordered that fine arenga leaf to be sacrificed. By walking in the master's footsteps, I am enabled to cut trees without asking permission, even of him! It was Jogee, lean, brown, and shrivelled, who this time walked among the long pinnate branches, that spring, one above the other, from the centre stem. He sat upon one leaf, and chopped at another with a long narrow piece of iron, slightly curved at the end; a most primitive tool. No tailoring annoyed his body. A piece of coarse cloth deftly fastened, without button or hook, was all sufficient. He picked up his bit of iron with his toes and passed it into his hand. Is he paleolithic or paleozoic man?

Talking of rats brings to my mind a dinnerparty where a funny thing happened. My neighbour was discoursing on a mutual acquaintance at home, when the lady on his right said ; 
"Do you know the name he goes by in his family? It is Rats!"

"Rats?!" remonstrated my neighbour in an inquiring tone, gazing at the same time through his eyeglass at a silver dish that was being held at his elbow by a dark-bearded butler. On the dish was an array of little glasses containing something dark, covered with whipped cream. The man thought the question was addressed to him, and at once replied in a reassuring tone:

"No, sir! Chocolate creams!"

- The laughter was simultaneous from us all.

I should like to tell a snake story that belongs to the C. S., only I know it will not be believed, which is a pity, as every word of these notes is absolutely true. It was this:- $\mathrm{He}$ saw a snake lying coiled in a hole among the roots of the peepul tree, and shot it. On dragging it out, he saw a large excrescence in the middle of its body. As it lay expiring, the lump moved slowly upwards towards its head. The snake's mouth was opening and shutting; it opened wider and wider, with a last convulsive movement, and out came a frog, looking dazed and torpid. It must have been 
undergoing the process of digestion, as it had already lost its hind toes; which sounds horribly, shudderingly, gruesome; but there is the fact, nevertheless. The C. S. gave it a kindly helping push towards the water, and in it went and disappeared. If that frog could only write its own memoirs, what an experience it could relate ; or the frog meeting Jonah, and the two fraternising over cheroots after dinner! The frog could give points to Jonah, as he had been half digested, though he had not been swallowed for a quarter of the time that Jonah had.

Well now, I have been getting on extremely well with my ferns that are to go in the C. S.'s new house, which is growing apace. I began on the day that the 2 inches of rain fell, when I was caught at the far end of the garden, with no possibility of getting home. Into the old potting-shed I went, and there I stayed till the storm was over. The shafts of lightning were very vivid, and the rain came down in cataracts. The fern earth was already dried in the shed, one part leaf mould, one part garden earth, half a part of broken-up roofing ; and with the assistance of an active boy, I then 
and there repotted 132 plants; three kinds of Adiantum, four kinds of Marantas and six other kinds of ferns. Very much astonished looked $\mathrm{Mr}$ Mahgun, the latest acquisition to the establishment, adopted by reason of his rose-budding propensities. The rain had ceased, and he appeared in a blameless jacket of snow-white calico, looking clean and respectable; while $I$, between heat, and rain, and mud, felt indescribably woe-begone.

Mahgun said, "If your highness will tell me which plants you need, I will pot them."

"Not so, my friend," I said to myself. "You may know how to bud roses, but you do not know how to grow ferns."

Two days after, these ferns had delicate yellow curls standing up from the old roots, the new fronds already.

"Let us now be up and doing," I told myself. "This month must see them finished, absolutely, so that they may get August and September rain and growth." So every day there was "no compulsion," except "must," in turning up sleeves and keeping at it, to the exclusion of every other idea. The boy and I have entirely replanted the Portico 
fern-house, the Lean-to, the Chamber of Horrors, and the Punkah-wallah's Walk, that three-tier fernery which is 320 feet long, as well as all the pots for the fern-house. None of it had been touched for the last four years, and I have made myself a most emphatic promise not to disturb it again for the next four. Ferns are none the better for being transplanted too often; and to say the least, the work in this climate is truly enervating. One does it, not for the pleasure of doing it, but to enjoy the look of it when done, and to see the rapid growth. I allowed Mahgun to pot my Achimenes this year, when he was new and presumably efficient. Daily and hourly I have watched for them to grow and bloom till now I fear it is too late, and for this season again, they are a failure. Last year I gave them too much sun. This year they have too much hard earth, but the aspect is right, north and shady. So I must try again next year in this position, with the same composition I give the ferns. They ought to have been lovely this month, with their purple flowers hanging in every direction, all round the pot or basket; quite beautiful objects. 
A little bonemeal would have done them good, but we cannot get Mahgun or any Hindoo to touch that splendid fertiliser. They say that human bones are ground up to make it, and that perhaps those of some relative or ancestor of their own may be mixed up in it; so a Mahomedan boy has to dig it out of the sack and mix it in the earth; after which the Hindoo consents to apply it where wanted. It does not seem to be of any consequence to the Mahomedan whether he is using his grandmother's bones to manure flowers with or not.

An old mango tree that lost its top in a cyclone, has taken a week to dig up. It must have been more than 100 years old. At last its roots were chopped off, and there it lay in the deep pit dug round it, but no amount of hauling could get it out. It was in the way of the new fern-house being built, so the C. S. advised digging still more under its head, and simply burying it as it lay. Many years hence it would become coal, he said, "but we shall not be here to see." Jogee and his crew did not see the force of losing their firewood, so with superhuman efforts managed after some days to 
chop it in pieces, and then they, with shrill shouts and "la-la-la-las," rolled it over to the old pond and down among the jungle, for their winter use. In England one would have had it sawn into garden seats and tables. Once I did have some plantstands made of mango-wood, but in a year or so they simply pulverised into earth-the effects of such a damp climate. So if one wants nice charming arches and seats, one has to use teak and sal, and even they must be tarred before being inserted into the ground.

This is indeed a busy month in the garden, now it is raining properly. To see how the jungle has grown up to Jogee's knees while he was chopping wood! Besides dividing and replanting all the ferns, etc., nearly every palm has been repotted also, and not before they wanted it. Some had become a mere basket of roots tied tightly in among broken bricks, with just the merest morsel left of original earth, and yet they were sporting green fronds 5 or 6 feet long. It was a marvel how they existed. Palms are a special "choc" of the Burra Sahib. He takes great pleasure in them, and knows how to grow them into things of beauty 
and grace; but so many outside claims to his attention have arisen this year, that he has no time for these, his children, and I try to be their foster-mother. The best, the Phœnix, the Areca Lutescens, the Plumosa, and the Rotundifolium, are in large tubs in partial shade under the south wall, where they remain evergreen the whole year round. It would be nice if they would stop when they have attained to a good-sized growth, but they will not. They grow and grow, and burst their tubs, and strike their roots into the ground, and some, the Livistonias, become too gigantic for anything.

Every fresh gardening coolie we get has to be instructed in the art of using the English wheelbarrow, a perfectly new form of garden implement to them. It is odd to see how gingerly they handle it, and how incapable they are of driving it straight, usually letting it wander and meander about, almost dragging them after it. When they arrive with their load, they cannot be induced to drive it up smartly and tilt its contents out in a heap. It is a most excellent wheelbarrow, all made of iron and tips up quite easily, but the coolie always empties 


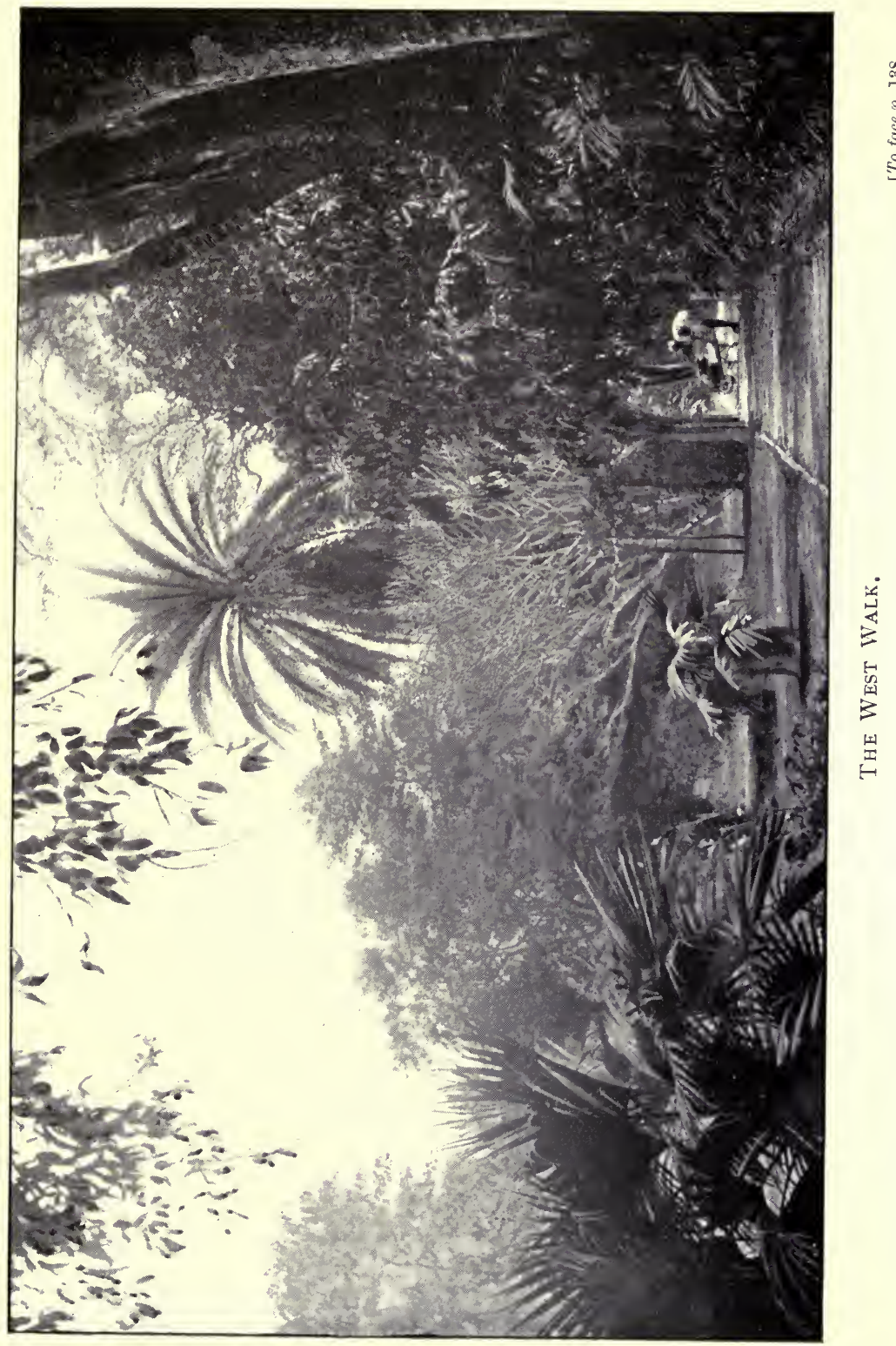



out the earth with his fingers, which is a lengthy process. I remember when it was ordered from the shop. There was also a request for an English spade and a ham to be sent at the same time. Much astonished was I to see a procession of three coolies arrive; the first one carried the ham on his head, the second the spade, and the third the wheelbarrow inverted like a cap on his cranium. It never occurred to them to put the ham and spade into the wheelbarrow and wheel them up by one man! So I had to pay for three coolies instead of one, which doubtless was their object. The barrow, now they have become accustomed to it, certainly does save time in bringing different kinds of earth from various parts of the garden to the potting-shed, but the spade has never been used, and one cannot wonder at it when a naked foot is all they have to drive it in with. Their method of digging is to loosen the earth with a pointed bit of iron, and then to claw it out of the hole with their fingers, or else to use a hooked shovel that chops the earth towards them. Both ways look to us very crude and uncomfortable. Still, with patience they are tolerably effective, only you must not expect it done in a hurry. That 
is why-I always annex the good-looking Mahomedan boy, whenever I can get him. He has a very dapper use of his fingers, is nervous, quick and active, and besides, he has a little knowledge of gardening, and a good deal of brain. He does not seize a tender fern by its new fronds, or try to get it into a hole too small for it; and best of all, he does not waste time. So I get along admirably by sitting under my two umbrellas, and instructing him with a long stick as to what to take up and where to put it, without many words of explanation; and I think he really enjoys the work. I said I was going to make a new rockery round an old mango tree in "Under the Mangoes," and told him where to get the earth and stones, and he accomplished it all by himself, much to the surprise of the Burra Sahib, who asked :

"How did you get your circle?"

"The boy did it, by his eye," I said.

$\mathrm{He}$ is very pleased when I give him a little reward of tea and sugar. In fact, they all like tea, and I keep a canister by me specially for them. When Penelope cannot get any money out of me, he comes and asks, always with a toothless smile, 
for a "little tea and sugar." I cannot imagine why they should think it necessary to smile when asking for anything, or in announcing a breakage, which they invariably do; because nothing on earth will make them laugh at a joke. To me it only adds fuel to the fire, to see a vacuous grin accompanying the remains of some favourite vase, and I say sharply :

"It's nothing to laugh about, why are you so pleased ?" I suppose it is a desire to conciliate in order to escape punishment, but on me it always has the opposite effect.

This morning I was presented with a "petition" written in English by a professional scribe sitting in the market-place. In it the lamplighter begged me to give him leave to go home to his country, as his brother was about "to do the married," and it was necessary for all the family and relations to be present. The scribes charge the servants a farthing each for these "petitions," which often send us into fits of laughter.

Just now all the berries are ripe on the Deodars. Every evening at dusk come parties of flying foxes, straight from the direction of the setting sun, and 
with loud flaps of wings, they settle in the trees to feed. Now is the time for taking pot shots at them, as chummeries mostly do, and I must confess, Unda and the C. S. used to. The servants eat them, and when one falls, they drag it away for their dinner. They say the taste is something like fowl. Nous rushed at one, and got a tremendous nip on the nose from the hooks on its wings, which I fancy he will long remember. Their wings when extended are something like 3 feet wide; their bodies are covered with fine fur, like a rat, and they have sharp fox-like heads.

29th. This evening at dinner we were all amazed at a statement made to us by the old Grey Beard; such a statement as one can hardly believe could possibly be uttered by any native in these days; especially by one who stands behind our very enlightened chairs and serves us all day long. He said that in every bazaar and all over the place, a fear has come over the people, so that no man dare go out into the streets after 9 o'clock at night alone; because it is said that after that hour he will very likely have his head cut off !

Pressed for the reason for this monstrous saying, 
the old butler informed us that it was on account of a new bridge that they had heard was to be built over the river; and that to strengthen the foundations, several heads were required, to be buried under the bricks.

We all fell back in our chairs, stupefied. We seemed suddenly to have been transported from this prosaic twentieth century, with its roast shoulders of mutton on our plates, and its Maréchal Neil Roses in front of us, and the native band in the distance playing most expressively Mascagni's Cavalleria Rusticana, back to some far-distant, wild, weird times when such deeds are said to have been possible.

"And can you," I asked, "possibly believe that such a thing could be allowed in any country of ours? For it is our country, isn't it?"

"Yes," he admitted, "it is your honour's country, and I do not think it can be true; but this is what every one is saying." Poor old man. I could see he half believed it, but was most anxious not to give offence.

"But," I said, "there is no bridge about to be built, and we are quite sure there is no Government 
order out for any foundations of that kind to be made anywhere."

"Then," he said, "it may be on account of the indigo, which has been failing so much of late, that now sacrifices have to be made to it."

"Sacrifices!" we all exclaimed, "what words are these? There is no indigo here."

"Us, your honour," said he, "but up-country where much indigo used to be grown, now the vats are empty, and in front of them are sacrifices being made to Kali of many goats and pigs."

The Burra Sahib assured him that he would not be made a sacrifice of, for any purpose; and one of the other servants remarked that such-like foundations for a bridge would not be very strong, for the heads under them would melt! 


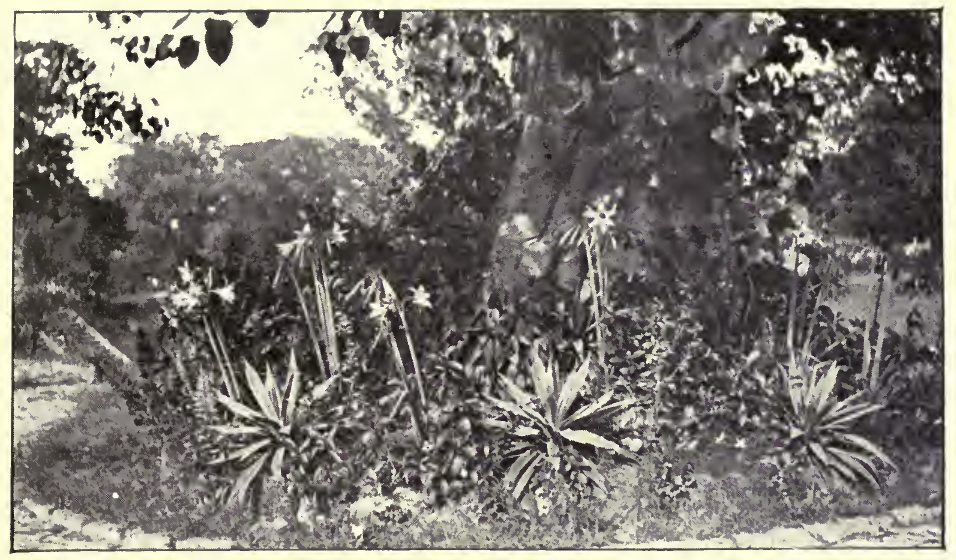

EUCHARIS LILIES.

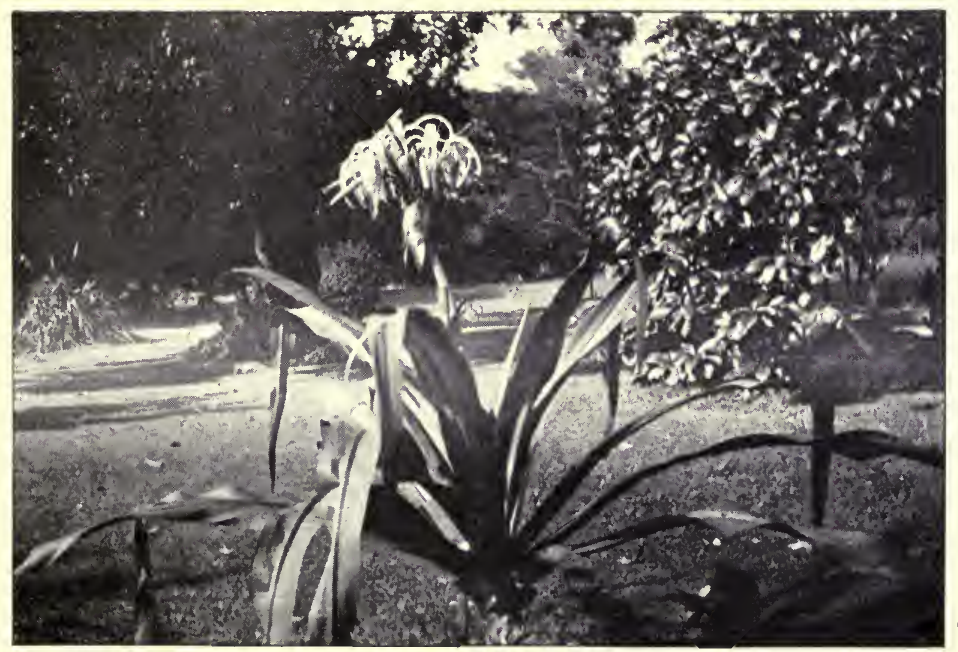

Crinum Augustum. 



\section{AUGUST}

"Now to sorrow must I tune my song, And set my harp to notes of saddest woe."

Milton.

If one wanted to photograph the movements of an opening blossom, one should select the Crinum Augustum. It is a noble plant, this lily; about 4 feet high, with scented flowers, numbering twentytwo in a bunch at the end of a long stalk as thick as a ruler. I passed by one just after a shower of rain this evening, and noticed that four or five of the 4-inch long, pink-striped buds were just ready to open. I came by again shortly after, and lo! and behold! they were open, quite wide open, too. In my next turn twenty minutes after, the long petals had entirely curled themselves backwards like ram's horns. One could see them all a-quiver with the intensity of the movement still. In one hour the points of those petals must have described 
an arc of 8 or 9 inches or more! This is even quicker than the Thunbergia, or the Ipomea, who both belong to the "fast set" among the flowers.

I was always under the impression that lightning did not strike during rain. Last year a large old Casuarina tree was blown down in a cyclone on to the north wall. This was one of a row of five that must have been planted when the house was built, so tall and old were they. In falling it destroyed a great part of the wall. It was found that the roots of these old trees had so undermined the foundation, that the whole of them would have to be cut down before the wall could be rebuilt. Now the difficulty was to find men to do it. Months elapsed before the work began, and there have we been all this time exposed to the road, and the immigrations of goats, dogs, jackals, donkeys, and buffaloes. In June the felling began, and the last tree was being attacked yesterday.

Suddenly a heavy thunderstorm came on, the rain poured in a deluge, driving the woodcutters down from the tree. It was fortunate for them they had descended, for a terrific flash came, striking the trunk of that very tree, and ripping the 
bark all the way down to the ground, which it entered. The concussion of the air was tremendous. I was sitting at the open window facing it only a few yards away, and the room was filled with the smell of sulphur. I went down stairs, and found that the old Grey Beard had been knocked down in the kitchen by what he described as a "ball of fire" passing the door, otherwise no damage was done. Dozens of natives ran up with baskets to pick up the bark for their firewood. To-day I see that the palm trees on each side of the Casuarina are burnt as black as a cinder ; so there is no safety in rain in a thunderstorm.

The dogs nearly always turn out some kind of "sport" when with me, and to-day they found a jackal in the jungle of the old tank. They have not had one to run after for some time, and they gave chase across and across the lawns, round the paths, in and out of flower beds, till Nous was ready to drop; but he would not give in. The jack is so much bigger, that they have no chance of ever running him down, and as Nous is asthmatical, he suffers extremely in a long chase, and quacks like a duck as he tears about; so I told the servants, 
who came running with sticks, to secure him. No use; the faster they ran after him, the faster he went after the jack, till the place was full of flying creatures, all wildly excited. At last, when the jack found an escape possible into the road, they were all fain to lie prone on the grass together, gasping. The jackals slink in somewhere, before the gate is shut at night, and lie hidden in the old pond jungle, waiting for an opportunity to get at my Chittagong fowls. Once they carried off three fine hens, and another time four ducks, by scratching a hole under the wire-netting placed all round the run by the Professor, who was then here. I was at that time smitten with the idea of giving the Burra Sahib two beautiful brown eggs every day, with his breakfast; such eggs as can never be bought; and the Professor aided and abetted me in arranging a palatial abode for some Chittagong cocks and hens, that had just been made a present to me.

"Now," said the Professor, "you want an incubator ; I will make one."

So an empty kerosene-oil box was requisitioned, and the interior fitted up in some mysterious way, 
with a kerosene lamp burning night and day underneath; and into this box was put twenty-one hen's and two owl's eggs. Patiently we waited twenty-one days, and even a day over, carefully keeping our light burning bright and clear the whole time, the Professor even waking up in the middle of the night to attend to it; but no little chirp was heard.

The Professor took out each egg one by one and opened them.

"Well," he said, "something went wrong. It was very nearly successful, for in each egg the chicken is formed, quite fully, feathers and all ; but when it came to the moment for breathing-then the arrangement must have fallen through somehow."

I suggested that perhaps, as he was only a Professor of Mathematics, he did not know how to make a proper incubator.

"Oh," he said, airily, "it was the fumes of the lamp that choked them. I have a good mind to carry the next lot about in my pocket, and see if I can hatch them myself."

"But then," I said, "how about tennis? And 
at night? You would be obliged to have them to sleep with you, not to allow them to get cold!"

So that idea was discarded, and we had to put up with the erratic hens, who either walked over the eggs, and smashed them; or fought with another hen for her nest; or else left the eggs to get cold. We succeeded, however, in raising a good number of pretty yellow fluffy chicks, but the vicissitudes they went through were so many, from crows and kites, and snakes, and being stamped on by their mothers, that really the Professor and I were occupied nearly all day in attending to them. I had over 100 at one time, and very promising they looked, and most engaging to watch and feed, but the Burra Sahib objected to seeing one before him on a plate. He said he didn't like eating pets ! One black hen, after being a great invalid for some time with fever, and carried about in a basket all day, became very tame. We would find her every morning sitting under the breakfast table waiting for us, and then she would meander about begging from everybody, and reaching up on tiptoe, with the dogs, to get little scraps from the master. No amount of driving out would keep her away. 
The sleeping Klinker would suddenly feel a peck at his tail, and would start up, with a remonstrating howl, but he would never touch her. When May came, with its torrid heat, and the Professor sailed away to his work, I found the trouble of the fowls too much for me, with half their interest gone.

So I hired a boy to do the work.

He departed and others came, and they either starved the fowls or fed them till their crops burst.

So I thought a comfortable bazaar woman would do better, and have some sense.

It turned out that she did not even know enough to place the wire cage flat on the brick floor, over a brood of young chickens ; consequently in the morning seven were missing. She had rested one side of it on a stone, so the rats found an easy way in.

Added to this, she had two of her own babies with her all day, who cried incessantly, like kids, which I abhor; so she got her dismissal, and was followed by the Imp. He did very well for a time, but oh! wanted such a lot of looking after; and I came to the conclusion that the master's two eggs a day cost a great deal more than they were 
worth ; and the fowls being gradually, slily, hidden in pies, my farmyard has now come to an end.

In nature here in this country, the mild, benign influences are few, compared to the vicious, malevolent ones that have to be so strenuously fought against. This is exemplified in the lawn grass. At first we laid down the fine kind known as "doob" grass, by dibbling in little bunches 4 inches apart; such a long business. It grew, was rolled and cut, rolled and cut, and looked very nice for six months. Then in crept weeds. These were pulled up. Still more grew, and coarse grass, which gradually has ousted every particle of "doob" that was ever there. Still when well rolled and cut in the cold weather, it looks good enough. It is now that it is such a trouble, for in July and August it throws up reeds that no machine will ever cut, and the whole place is like a hay field. Three men sit down to pull up these weeds by hand; when they have cleared a space they go over it with the machine, and these three men can do nothing else for weeks ; for directly they have come to the end of the lawns they have to begin at the beginning, all over again. As I look at them from the verandah, I see that 
Jogee begins to look wrinkled and careworn. No wonder, with such a number of miles to traverse with a mowing machine, half at a run, as they take it, two pulling and one pushing. After September it ceases to grow at this rate; which is fortunate, as all hands are wanted then for the annuals.

Looking at Jogee reminds me of his brother "Gunga," who was gardener to us for ten years, and only left our service on account of having been bewitched, as I might have written in his "character," but did not. He fell ill with fever, which went on week after week without cessation. Quinine did not touch it; a native doctor did no good. At last Gunga said he was possessed with a devil, and that he had seen the "bhoot" in the middle of the night; and he was 8 feet high, with arms outstretched like the branches of a tree. Therefore he ordered a juggler, a mystery man, to be brought, to expel the evil spirit from within him. His relations brought one, and Gunga was so foolish as to give him 5 rupees for his ministrations. All to no purpose; the fever remained as virulent as ever. I wanted him to go to his 
country, but he was really too ill to travel alone, so I suggested sending him to the hospital. Hated word! to a native, though I cannot imagine why. Anything rather than that. So he secretly sent for another juggler, though I had told him not to waste any more money on such a foolish thing, but to drink the new medicine and the milk I sent him every day. The jadoo-man did come, however, and I heard afterwards that seven of Gunga's friends sat round him in a semicircle, while the jadoo-man made three marks on the patient's arms with a piece of chalk-like substance, then rubbed it with a holy stone from the Ganges, all the while chanting incantations and burning incense. Suddenly the evil spirit in Gunga made him rise up in a sitting posture, after he had been lying for days, too weak to move a finger, unassisted. So the story goes. He began to rock backwards and forwards. The juggler, addressing the spirit, said slowly three times :

"Will you come out? Will you come out? Will you come out?"

The devil, in Gunga's voice, answered, "I will come out." 
Then he lay down and fell into a deep sleep. The next day when I went to see him, I saw that the fever had broken for the first time.

"There, that is my new medicine. It has done you good already. Make him continue taking it," I said to the others. Not a word was said about the juggler till some time after, but Gunga continued to mend slowly, such a bag of bones as he had become, and of course it was the mixture that was doing him good, whatever he might think himself. I know he took it, for I made Gobin pour it down his throat.

"Now," I said, "is there anything you can have to eat, to begin to get up your strength with? Of course you must not touch curry and rice, and beef-tea you may not drink, I suppose, even in illness."

In a faint voice Gunga said, "I should like some kid-soup."

"Kid-soup," I exclaimed, "where can we get kid-soup?"

"Poonia can make it," he said; "but the kid must be brought from Kali-ghaut."

So Poonia had to trudge all the way to Kali- 
ghaut with the mistress's money to purchase some of the kid that was sacrificed every day by the priests in front of Kali's shrine. It did them both good, being vegetarians. Poonia had a beatific expression on his face afterwards. No doubt he had the bones to suck. As soon as Gunga could walk, I paid his fare home to Orissa, where he went escorted by some friends. He was not much of a gardener, but could work hard. He had a peculiar voice that could be heard all over the garden. The master said it was like a bumble-bee. $\mathrm{He}$ tried to translate it into the vernacular in order to address him by the name of "Bumble-bee," but the nearest he could get to it was "Biting-fly."

"Here, you Biting-fly, come and dig this up," at the same time mimicking the sound of a bumblebee. Gunga had not the remotest idea why he was a biting-fly, but if the master said he was a biting-fly, what could he do? He was a poor man. The Ancient once thought, by the way, that he had a biting-fly inside his hat. It was Proclamation day, and a feu-de-joie was suddenly fired off on the parade ground, half a mile away.

"Good lord!" cried the Ancient, "what's that 
inside my hat?" snatching it from his head, and flinging it to the ground. We shouted in his ear that it was only the feu-de-joie.

"Oh," he said, "I could not think what awful beast it was, buzzing round and round inside my hat. It was like a great bumble-bee !"

I said to Poonia: "You are very foolish people to throw away 5 rupees, twice over, to jugglers, for the purpose of casting out devils. Do not do it again. You do not believe there are "Bhoots'?"

"There are many," said Poonia.

"Where?" I asked.

"Here in this garden there are some."

"Oh, that's why you all rush away from your work the moment dusk falls?"

"Yes," said Poonia. "There are also many in the road at night, and no man will walk there alone after nine o'clock."

"What are they like?" I wanted to know.

"Some are like men, some are like cows, and goats, and pariah dogs."

"But they are those animals themselves!"

"Once a man was ill, and a 'bhoot' like a cow came to the house every night, and he died." 
"Well, Poonia, I don't think you will ever meet with anything worse than yourself in the garden, so don't be afraid."

A civet cat has been seen again, up a tree, watching the pigeons. The other night the dogs caught it in a drain. I could not think whatever it was, giving out such a piercing yell, and the master went out with a stick, and caused the dogs to let go. Then, as it bounded away, we saw it was a civet cat. A year or two ago, six at a time, one after another, ran along the top of the wall flourishing their long bushy tails, banded with yellow and black. They have sharp noses and tiny paws for their size, with very sharp black claws.

The Professor caught one with the aid of the dogs, and skinned it, and set up the head, paws, and tail, on a board for the decoration of his room, in company with the 7-foot-10 rat snake, and a few other choice articles.

When he and the C. S. were tiny boys, I took them to see an orphanage school treat. After inspecting the lines of motherless children, sitting at tables whereon were plates of cakes and oranges, 
they went back to the carriage with hearts, as I imagined, full of kindly pity. As we were getting in, the future Professor remarked :

"Mother, I wish I was an orphan!"

The guileless simplicity of it! He had had his eye on the cakes and oranges !

They had a funny little man to take care of them in those days when out of my sight, named Buldao. He was, many years after, the father of Billy Doo. He had only one eye, like his brother Gobin, and had an intensely earnest manner.

Servants in England sometimes drop their "h's," but out here our ones generally seem to have dropped their "i's," for we have no less than six one-eyed people in the compound, poor folk.

I remarked to the Ancient, who was not very antediluvian then :

"Why does Buldao wear his waistband right up under his arms like that? It must be very uncomfortable, and looks as if he has outgrown his clothes."

The Ancient had him brought before us.

"The mistress," he said, "is inquiring for what reason you are so short-waisted." 
Buldao looked frightened. He was afraid he was disapproved of.

"It is the custom of my country," he said, "to have a short waist; but if your honour orders, I will make my waist lower down."

What was to be done but laugh? So Buldao has remained with his waist up under his armpits even to this day. Everything had to be explained and translated to me in those times, which was fun, but $I$ acquired the language sooner than the Burra Sahib. Leaning out of the window one day, I overheard him in conversation with his groom, after a two years' residence in the country. He was looking at his riding-horse, which appeared out of condition.

The master said, "Horse ill. Don't eat grass."

The groom answered sedately, "No, my lord," and that was the whole of the conversation.

A foreign friend once had the same sort of struggle with his English, which was within an ace of leading to the most disastrous consequences. He had bought a beautiful young horse just up from New South Wales, and sent it to the Vet. one day with a note, saying, "Please have my horse 


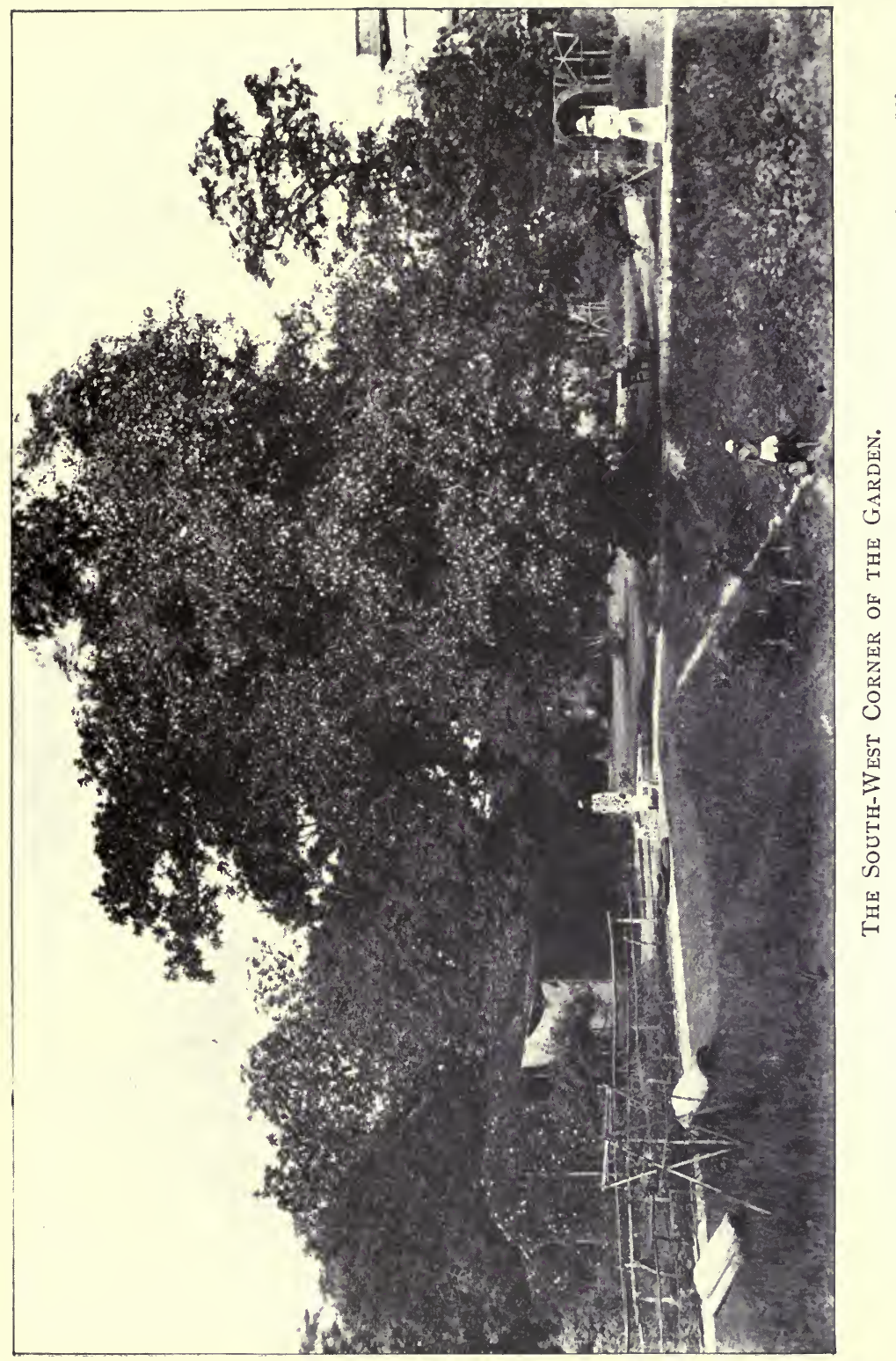



shot." Back came a letter. "Dear sir, I have examined your horse, and see no reason why he should be shot. Please explain." In the greatest haste the terrified owner replied, "It is a mistake. Please shoe my horse!"

Having finished my long fernery, to the great improvement of that south wall, and all being done in that direction ready for the cold weather, I have now turned my thoughts to the leaf-mould corner, at the junction of the south and west walls. We have always agreed that that would be an ideal place for ferns, but it seemed rather a stupendous undertaking, owing to the absence of any rubbish wherewith to raise it above the front semicircular row, which has had ferns for four years. Now that the stables have been rebuilt, there is a quantity of suitable material lying there which requires removing, in order to tidy up the stable compound.

"At last, therefore," I said, "we will make a fernery in the corner."

The first thing to be done was to remove all the stored leaves from many garden sweepings out near by on to the grass. On the top were simply lately dried leaves, and these were placed in a 
larger heap by themselves; but underneath there was splendid pulverised leaf mould, all ready to go on the top of the fernery by-and-bye. So a separate heap was made of this. Now begins the slow work of conveying barrowfuls of bricks from the extreme end of the premises, the north-east, to this corner, the south-west; and I feel that perhaps it may be done by Christmas !

And now has come the rain, and stopped everything. It is making up in inches for what we ought to have had in July, torrents of it; but all gardening is at a standstill; and there is nothing to be done but take a solemn drive with the dogs in the evening, when the rain has left off sufficiently, and fetch the Burra Sahib away from his work. How they love coming with me, those little animals! and how dull I should be without them. When six o'clock comes, Klinker knows it is driving-time as well as anybody. If I am still in the garden, he comes and stands in front of me, then makes two steps to the gate with anxious eyes on me, and then back, dancing and quivering before me. Quite plainly he says :

"How can you stop in this stupid garden, when 
you can go clattering along the road, with two imperious grooms standing up behind, calling out to the foot passengers, ' $\mathrm{Hi}$ ! you umbrella man!' or to the bullock carts, in a tone of seemingly suppressed fury, ' $\mathrm{Hi}$ ! you sacré wallah!-Get out of the middle of the road, and keep to the side." "

"Well, to please you, Klinker, I will go," and then he is in the seventh heaven. He seems to go and tell Nous I have gone to dress, and they come and watch me through every detail. When the dress goes on, they sniff at it, to see if it is the proper going out one; and when on goes the hat, they get wild, and precede me downstairs, bumping and charging into each other for very fun; and up on the seat they bound, one each side of me, Klinker with his fore-feet on the edge of the door, uttering growls and barks of excitement and defiance at every street dog he sees; Nous quietly happy, as befits an elderly gentleman. On returning, they are let out at the bridge to scamper home. Klinker stands with one foot extended, toeing an imaginary line, and eyes on the horses, ready to pace them when they start again. But he is always home first, and 
waiting on the doorstep to receive us with joyful shouts of welcome. It is the master's custom to share his tea with them in the early morning. One morning Klinker drank his when put on the floor, then watched the master preparing another saucer for Nous; a little milk and a little sugar well stirred, then put down on the floor. "Nous!" "Nous!" called the master. Nous lay behind a screen a little way off, and wouldn't come.

"Nous! here's your tea," again called the master. "Here, Klinker! go fetch Nous." Klinker got up and with his head down in a rather grumpy attitude, walked slowly straight across close to Nous, and in his ear gave one short bark, no more ; then came straight back and sat down. At once Nous got up, and came and drank his tea, and the master and I both burst into a laugh; it was so quaint, and exactly as if they both understood. Who shall say they did not?

20th. My gardening notes are very doggy this month, but the rain is responsible for that. The new fern-house is also at a standstill, but everything that has been transplanted is growing exceedingly. 
After all the rain we have had, we thought we would try a little fishing in the big pond, where one can always see great mouths opening for flies on the top of the water. We each held a rod out patiently for hours, with a hook at the end on which was an enticing pellet of bread and cheese, but never a bite did any of us get, though we could see the fish disporting as usual. We then tried worms, but with no better result. We had four or five servants waiting to bring bait, or to carry in the fish; but it ended in their only taking in the empty rods.

"I will have those fish," said the C. S., "in a net, to-morrow morning." So we all uprose very early, and watched the men dragging the pond. The C. S. did indeed get his fish. One weighed 10 lbs. ; two more, exactly a pair, each weighed 21 lbs. ; and many more were a very respectable size, while numbers were thrown back again. So the fish were there all right, only we could not catch them. We have heard since, that they require snails as bait. The servants revelled in their fish dinner that day. We tried one ourselves and it was very good indeed, but somewhat solid. It was 
either a cutlah or a rooe. It is difficult to say which.

24th. Everybody awakened this morning by hearing some tremendous cracking noises, four in succession, quite close. The rain was coming down in cataracts, and had done so all night. My first impression was that the verandah was giving way. Then when I was thoroughly awake I knew it was a little farther off, at the end of the garden. We got the glasses and looked, and behind the others we could distinguish a great tree down, sprawling, full length, over the pathway by the south wall fernery and the Chamber of Horrors. There was not a breath of wind, so that it had simply stood still and fallen down, with the sheer weight of water.

"My palms!" exclaimed the Burra Sahib in despair, "all smashed; they must be, the tree is right across the tubs."

"My fernery," I sighed, "and it was looking so nice and I did not want to have to do it again for four years." We dressed ourselves in mackintoshes and top boots, and went out into the pouring rain to know the worst at once. It was indeed a scene 
of desolation. A magnificent large mango tree, the monkey tree, had fallen straight over from the roots, exhibiting a large hole in the ground, and a hollow trunk devoured by white ants. The weight of water had borne it over from such a slight support in the earth. In falling, it had struck a kuddum tree near, and knocked the whole of its head and half its trunk straight over the top of the wall, where it hung in the Mahomedan burialplace. That, in falling, came in contact with a great date-palm tree on the other side of the wall, and levelled it to the ground, and there lay the three giants perfect wrecks. Ours was along the path, blocking it for some distance, and an elbow had buried itself deep into the earth; but strange to say, it had missed most of the tub palms, and seemed to have fallen mostly in and out of them, so though the present beauty of them is disfigured by broken fronds, none are irretrievably ruined, though it will take two or three years to put them right again. Nor were my ferns all badly damaged; but everything was pinned down by the mango branches. As soon as it cleared a little, we had ten men cutting and lopping away; and then I 
found it necessary to stand by all the morning and advise, while they gently rescued the wounded plant below, and bound up its broken limbs, before any further damage was done; for all the world like a human disaster. The delicate Plumosa, 20 feet high, was flattened to the ground from its tub. Poonia got hold of one leg, and thought in that way to pull it out from the weight above. I made him cut away all the branches from over it first, and then raise the whole plant together, carefully. By good luck it was only bent over, not broken, and with the aid of splints and bandages and wooden legs, we set him upright again.

There is indeed enough gardening now for some time, and I am down there all day rescuing my ferns from the débris, and propping up their wounded limbs. The thickest portions of the trunk are in the roadway, and a month of chopping will not get it clear as to enable the pieces to be carried away, they must be chopped to a convenient size, and that means a great deal of work. The circumference of the trunk is 25 feet. The upper branches fell right into the Chamber of Horrors, into a bed of Dracænas and Heddicums, and smashed my 
pine-apple plant, off which I had one fruit this year for the first time. Such a wreck everywhere! but looked at from one side, it is very picturesque, and that nook would form a lovely setting for a pastoral play. The fallen tree with extended branches covered with leaves, would give several rustic exits, and if only Unda were here, it would be delightful to get one up. I will leave the principal part of the tree lying as it fell on the grass, and get in some sawyers to only cut the road clear; and I will cover that trunk with all the orchids and tree ferns I can get, and have quite a change of scenery down there. The worst of it is, that it lets in the sun now just where it is not wanted, and by-and-bye everything will be burnt up to a cinder. Unlessa bright idea has struck me! There are five great fish-tail palms over by the stables, excluding light and air from where they are wanted. They are quite 20 or 25 feet high. If I could dig them up and transport them bodily down here, they would look lovely, and shelter the tub palms and ferns below.

I went and consulted with Jogee.

"If I give you four outside coolies, can you move those palms?" 
Jogee thought he could, with every other available man to help to carry them.

"Begin at once," I said. "Get your men. This is a splendid time to try the experiment, after so much rain, and more coming."

I got it done in one day and finished. What was the master's astonishment, on walking round there this morning at his usual rate of 4 miles an hour (at which pace, I tell him, it is impossible to garden), to see a tall row of thick palms, suddenly! - where before was nothing-all beautifully fresh and green.

"You have been going it," was his remark. They absolutely did not know they had been moved. They were not out of the earth more than twenty minutes, for I had each one planted at once in the pits ready for them, and well stamped in. It was such a noisy business getting it done, but I am delighted with the look of it now, and it answers the purpose admirably. The dogs have been wildly excited with the fallen tree, and explored it all over, especially as it retained a very strong odour of the monkey among its upper branches, now near the ground.

To-day the monkey himself made his appearance, 
seeming to be quite as much exercised in his mind about the disaster as the dogs were. He flopped on to the wall, and led the dogs a good dance up and down from end to end, several times. Then he got bolder, and ran down a broken bough right into the garden close to me and ensconced himself in his own odorous branches. Nous was after him, as high up the trunk as he could get; but the monkey dodged him and Klinker from place to place, seemingly on purpose to tease the dogs. At last I drove him away with a stick, and he sat in a tree on the other side of the wall, whence he could just see me over the top; and every time I looked at him, he mouthed at me, which I returned with interest. He is a handsome fellow, with very black face and feet, and bright red brown body, covered with long hair; nothing like the weedy hairless, specimens seen in most Zoos, but in perfect condition. Kipling must have been feeling the hot weather rather badly though, when he wrote:

"An inscrutable decree

Made thee a gleesome,

Fleasome Thou,

And me a wretched Me." 
It really seems now as if the worst part of the long-drawn-out hot weather is nearly over, because the cold-weather seeds have arrived. Mahgun must dry and sift some garden earth, 1 part; leaf mould, 1 part; and sand, 1 part, and start on with his seed-pans at once for pansies, heliotrope, asters, and various things that want sowing by the end of August under shelter from rain. They take longer to germinate than pinks and phlox. I am delighted to have saved a nice lot of chrysanthemums through the rains, and hope to have some brilliant specimens this cold weather, for the very first time. A few heliotrope, too, I have managed to keep, and they will bloom much sooner than seedlings. The dahlias are planted out in pots, and doing well. Now there are two things I must make a point of getting specially, as they are never included in the seed box - nicotiana and hollyhocks, if it is not already too late. I never have grown them yet, and want to try to do so this year. I have seen very good ones in other gardens sometimes. I think a goodly number of violet plants will have survived the rains this year, and I expect there will be about 800 pots, when planted out in October. 
It all depends on giving enough light and air with a minimum of rain and sun, whether they can be preserved or not. Although there are so many beautiful indigenous plants that do well, we are never satisfied without putting forth all our energies to grow foreigners; the English home flowers in particular. Such pampering, and petting, and spoiling they get. Such sifting of earth for the seeds; such protecting from ants, by standing their pans in other pans of water; such shading from too much sun during the day; such fine watering, not to swamp them! Yet in spite of all one's care, they often run up leggy, tumble over and die, or rot in a sudden shower of rain, that sometimes three successive sowings have to be made. Geraniums we desire much, but they are also "kittle cattle." Last year we gave them too much room, and they went to leaf principally, and every one of them has departed this life during the rains. Now we are going to start with a fresh lot in October, from the hills, and keep them in pots, sinking them in the earth; and see if that will suit them better, to be pot-bound; then surround them with blue lobelia and feverfew. Hey! presto! how 
familiar it will look. Mahgun has enough to occupy him just now in weeding his new rosary. The new red-brown plants are only a foot high, but he declares they will have roses on them next January. Then Unda and the Ancient may have their "battle of flowers," again, after the one-day blossoms have served their purpose at dinnerfilling the room with rose-leaf sweetness and tonic merriment, and raising the spirits of the ditchdwellers. As Mahgun sits at his work, I almost think I can see the weeds growing under him. He leaves them in bunches for one night, and next day they are growing again. It takes him some days to get all over it, and certainly by that time he ought to begin afresh, as they are all up again the same as at first. In parts of the garden that have not been touched, the broad-leaved grass and the wild alocasia are 4 feet high, all mingled with a dense creeper, bearing white starry flowers, that afterwards turn into a bright red fruit, beloved by birds. How lovely the trees look when in the rains they are covered every evening with brilliant shimmering fire-flies ! Thousands of them quiver in and out of the 
branches, trembling and scintillating like fairy pyrotechnics.

31st. The long-dreaded tragedy has occurred. Yesterday my two dear little dumb companions were killed by a cobra. At about 12 o'clock I was superintending the transplanting of some tall roots of alocasia between the fish-tail palms brought from the stables, when, some little distance off, Nous began to bark; his usual warning bark when he has found something. Away went Klinker from my side to join him, over in the fern corner. I imagined it to be the monkey again, and glanced up above me two or three times, expecting it to come bounding along the top of the wall. I did not want to be taken unawares, and perhaps suddenly find it clawing at my face, being in my secret heart in mortal terror of monkeys, since I was jumped on as a little girl and fiercely bitten by one. I saw nothing of it though, and continued planting till the door-keeper came with a letter, when he said :

"The dogs have killed a snake." At once I went to look.

"Where?" I asked. 
"Here," he said, "is a piece."

Quite near me Klinker had deposited it, and now seized it again. I turned it over with my foot.

"I think it is a damon, a rat snake," I said. "If we could only find the head."

The door-keeper thought it was a cobra, and showed me where the rest of the body lay, in two long pieces, some distance off, but without the head. Nous now came running up to us on three legs, holding up one paw in the air for us to look at. I examined it but could see nothing, but blood was on his neck.

I said, "He must have been bitten."

"No," said the door-keeper, "that is the snake's blood," so, as I thought still that it was a damon, I merely said :

"Tell the sweeper to wash him," and went back to my planting.

"He is away at his dinner," said the doorkeeper.

Klinker now came and lay down on a soft part of earth, close to me, as if he were resting after his exertions. They always did so after killing a 


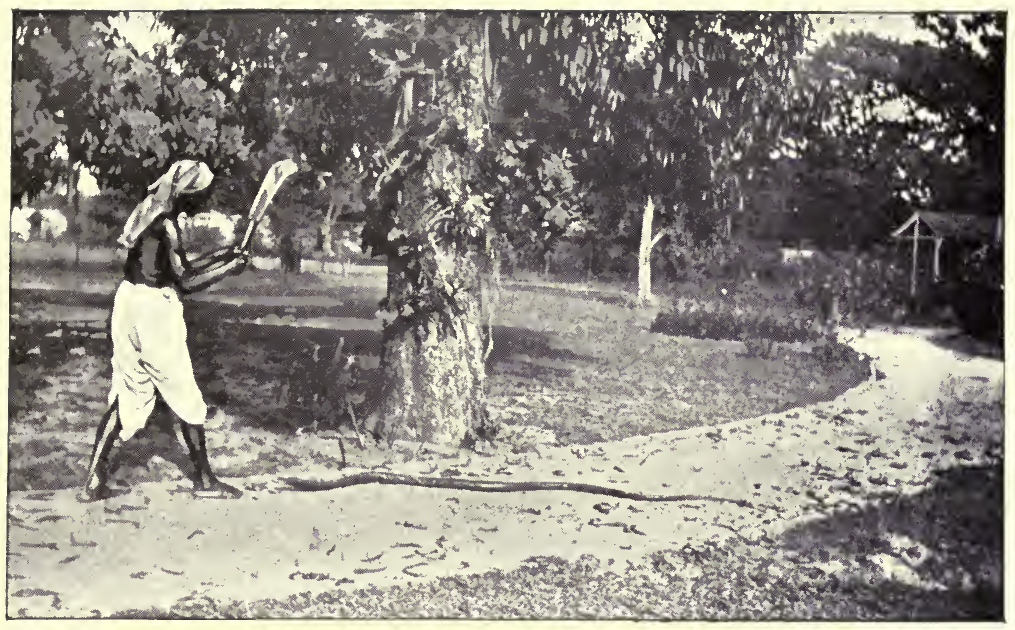

JOGEE AND DAMON.

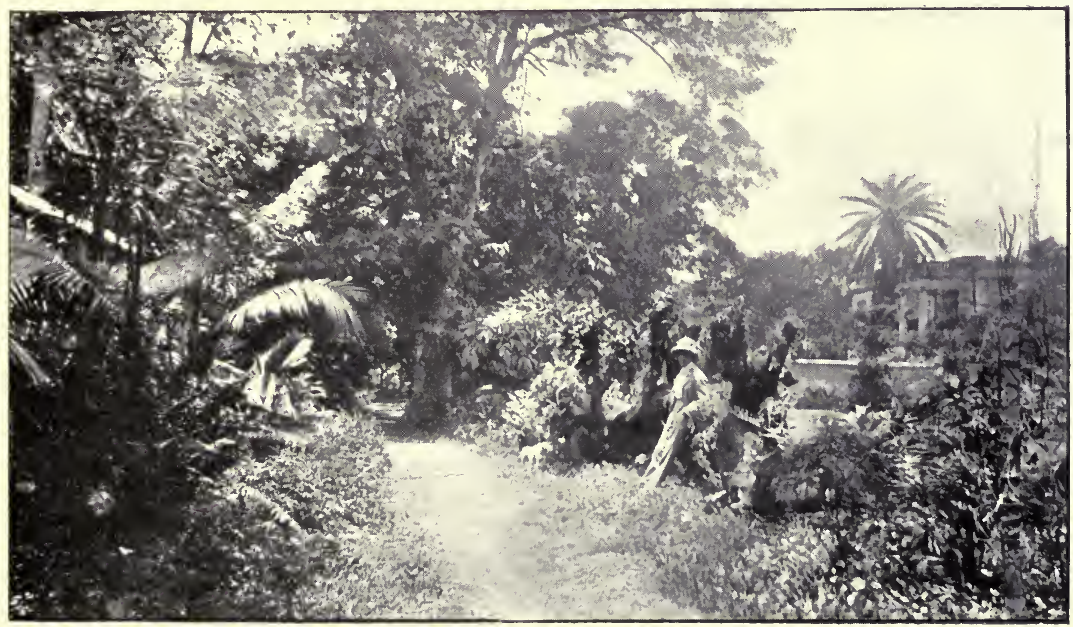

The Dogs' Last Battlefield. 

snake-which was panting, exciting work-and Nous came and lay down close to my chair, in a comfortable attitude, as if he were going to sleep. In a minute or two I heard Klinker growling as if he were talking in his sleep, and I noticed him rubbing his chin up and down on the earth. I thought he was playing, and went over to look at him. He did not get up, and then I saw something was the matter.

"He is dying! he has been bitten," I said.

"Yes," said the coolie, "he is dying."

I then looked at Nous. He had pushed his nose over to the soft earth, as if he were trying to get into it, and lay there. My heart stood still.

"And Nous! dear Nous?"

"Yes," said the coolie, "both are dying."

"Call the door-keeper, call everyone," I shrieked. "Oh! what can be done?"

Brandy !- up to the house I hurried, while the tears blurred my eyes. Oh! the distance it wasinterminable. Brandy and a spoon I brought. By then there were thirty people assembled. Brandy was poured into each dog's mouth, but it was too late. They were both just dead, painlessly it 
seemed-no struggling, only a sleepy lethargy, with two or three wide yawns at the last, and not more than ten minutes after they lay down; but what was their instinct to rub earth on their wounds? Klinker had been bitten just under the chin-I found four distinct marks of fangs-and Nous on the ear. I could see nothing on his paw. I knew now it must have been a cobra. I said :

"Find the head," and we all searched. It was nowhere near the body. At last it was found quite close to me, where I had been working. Nous had been bringing me the head, as Klinker had a portion of the body, and had left it under the fallen tree. I pressed a stick on its neck, and the hood was there, all loose, and spectacled. An undoubted cobra. If I had only known in time! But nothing on the wide earth could have saved them. They were evidently bringing me the pieces to get their accustomed pat, and "good dog," after killing a snake. This time they got neither, for they were covered with blood, and I was mainly wondering what kind of a snake it was. After finding the head, I tried to trace back to where the dogs had first found the cobra. I could not have 
believed there were still any left in the garden. Some little distance from where the mangled body lay, were the large heaps of dead leaves that had been taken out of the corner to make the new fern bed. On the softest bed of this leaf mould was the sign of a scuffle; and there the attack must have occurred. The soft earth was a disadvantage for the dogs, and when they sprang at the cobra, it must have prevented their aim being true, and the cobra got his teeth in first. Even had I gone to their assistance when I heard them barking, it would not have prevented it, for as soon as reinforcements arrived, they always attacked at once, and no amount of calling off would have got them away, the brave dogs. Had they been on firm ground it would never have happened. They were always quicker than a cobra there. I feel I have lost two devoted friends. Who will now warn me of danger? Never did I go round the garden without those dogs acting as scouts on each side of me, searching out and warning me of everything that was inimical. Had I passed by that heap of leaf mould alone, I should never have seen the cobra coiled up, so nearly the same colour as the earth. 
Further examination revealed a round hole out of which it had evidently crawled. My idea is that it was reposing in the middle of the heap quite quietly till the coolie went and took out two handfuls of the leaf mould to bring me; in doing which he must have as nearly as possible touched the cobra with his bare hands. Finding its peace disturbed, it crawled out, and it was then that the dogs saw it. It is explained how it came to be there, by the existence of a hole in the wall, made to let out the floods last year, into the jungly Mahomedan burial-place; the veriest breedingplace for snakes. Instantly I had it filled up to prevent its pair coming in search of it. Probably this is the one Mahgun saw the other day, near the potting-shed, where also was a hole, in the wall. That one opened its hood at him, then swiftly slid up a tree, whose branches overhung the wall, whence it dropped over out of sight. I also, sitting in the shed, heard snaky rustlings overhead in the thatch one day, and concluded at once it was mankind's direst enemy, a snake; but thought it was safest not to try to look for it. If only I had had those holes filled in before! This morning the grieved 


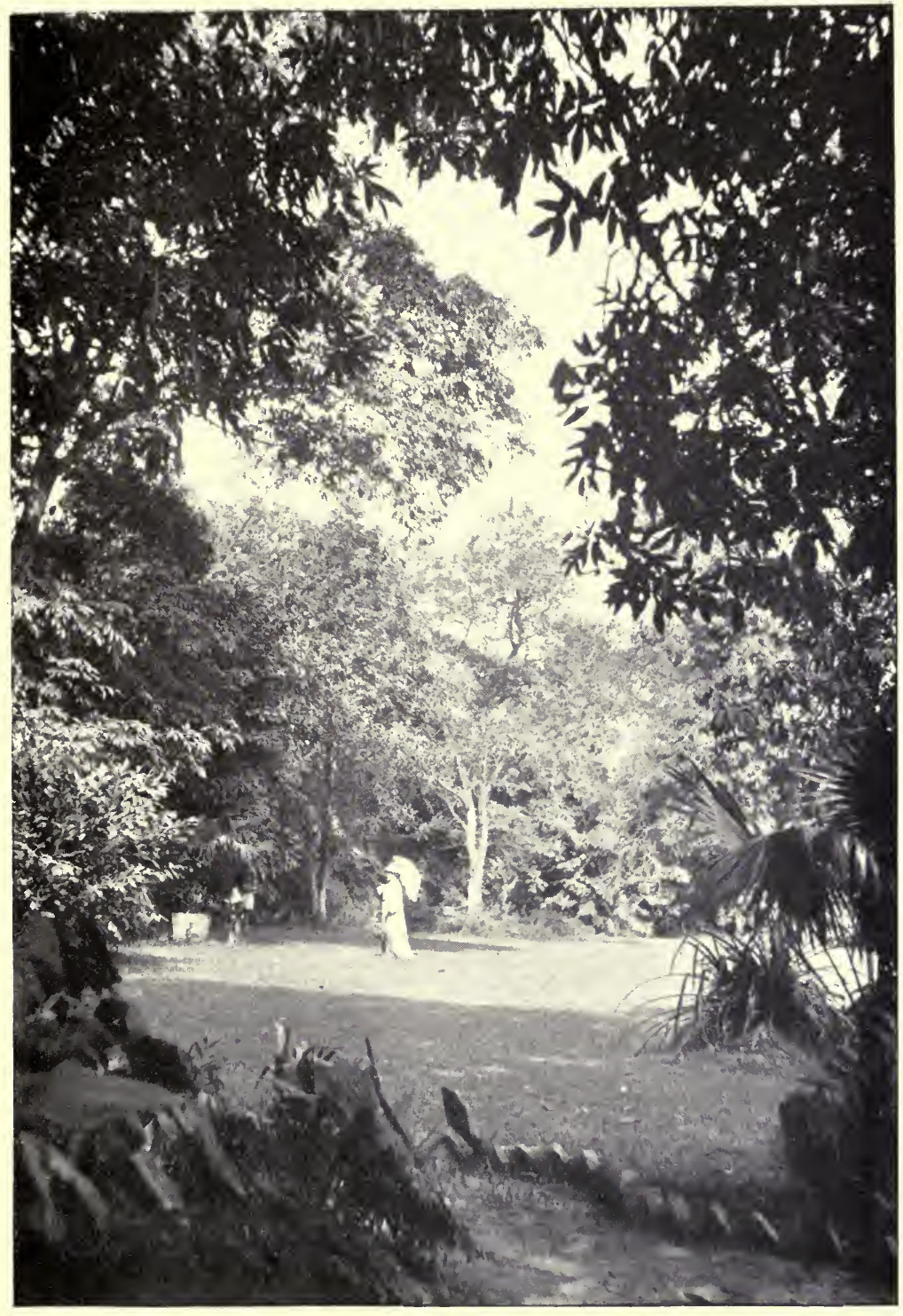

The Drop Scene. 

master got up early and buried the two dear dogs, in a place I had previously pointed out to him, straight in my daily walk under the Frangipanni tree. A tiny headstone will mark the spot where lie, in one little grave, the two friends who never harmed a human being; but who, together, battled with enemies of every kind-jackals, langours, civet cats, rats, pariahs, geckos, and cobras-and met their tragic end together in killing their mistress's greatest foe.

"The day is done, and the darkness Falls from the wings of night, As a feather is wafted downward From an eagle in his flight.

"And the night shall be filled with music, And the cares that infest the day Shall fold their tents, like the $\Lambda$ rabs, And as silently steal away."

LONGFELLOW. 

PRINTED BY

OLIVER AND BOYD

EDINBURGH 




\section{LIBRARY USE}

RETURN TO DESK FROM WHICH BORROWED

\section{LOAN DEPT.}

THIS BOOK IS DUE BEFORE CLOSING TIME ON LAST DATE STAMPED BELOW

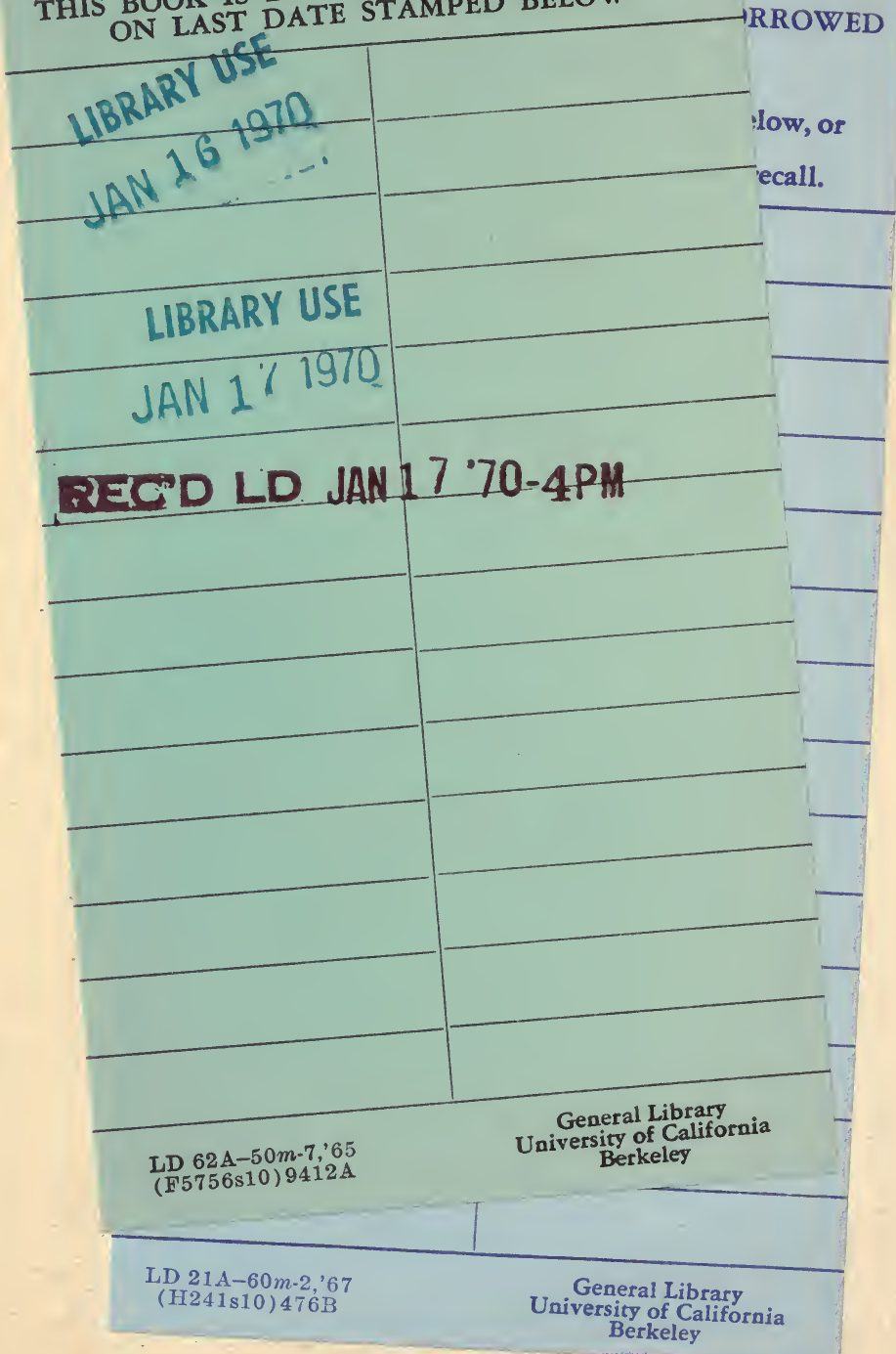



